Florida International University FIU Digital Commons

$11-10-2016$

\title{
Government Capacity and the Acquisition, Implementation, and Impact of ARRA Funds
}

NakHyeok Choi

Florida International University, nakhyeok.choi@fiu.edu

DOI: 10.25148 /etd.FIDC001252

Follow this and additional works at: https:// digitalcommons.fiu.edu/etd

Part of the Public Administration Commons, Public Affairs Commons, Public Policy Commons, and the Transportation Commons

\section{Recommended Citation}

Choi, NakHyeok, "Government Capacity and the Acquisition, Implementation, and Impact of ARRA Funds" (2016). FIU Electronic Theses and Dissertations. 2973.

https://digitalcommons.fiu.edu/etd/2973

This work is brought to you for free and open access by the University Graduate School at FIU Digital Commons. It has been accepted for inclusion in FIU Electronic Theses and Dissertations by an authorized administrator of FIU Digital Commons. For more information, please contact dcc@fiu.edu. 


\section{FLORIDA INTERNATIONAL UNIVERSITY}

Miami, Florida

\section{GOVERNMENT CAPACITY}

\section{AND THE ACQUISITION, IMPLEMENTATION, AND IMPACT OF ARRA FUNDS}

A dissertation submitted in partial fulfillment of

the requirements for the degree of

DOCTOR OF PHILOSOPHY

in

PUBLIC AFFAIRS

by

NakHyeok Choi 
To: Dean John F. Stack, Jr

Steven J. Green School of International and Public Affairs

This dissertation, written by NakHyeok Choi, and entitled Government Capacity and the Acquisition, Implementation, and Impact of ARRA Funds, having been approved in respect to style and intellectual content, is referred to you for judgment.

We have read this dissertation and recommend that it be approved.

Milena Neshkova

Shaoming Cheng

Ali Mostafavidarani

Hai Guo, Co-Major Professor

Howard Frank, Co-Major Professor

Date of Defense: November 10, 2016

The dissertation of NakHyeok Choi is approved.

Dean John F. Stack, Jr Steven J. Green School of International and Public Affairs

Andrés G. Gil Vice President for Research and Economic Development and Dean of the University Graduate School

Florida International University, 2016 
(C) Copyright 2016 by NakHyeok Choi

All rights reserved. 


\section{DEDICATION}

To my precious parents, WolRyun Kim and WonHo Choi, and my wife, NaHyun, and our love, Jiwon (Eddie). 


\section{ACKNOWLEDGMENTS}

The entire journey for this dissertation could be finished due to the support and assistance of many people. First, I am deeply indebted to all committee members: Professor Howard Frank, Professor David Guo, Professor Milena Neshkova, Professor Shaoming Cheng, and Professor Ali Mostafavidarani. Their critiques and suggestions guided me to the right path to complete the study in a timely manner.

Furthermore, I wish to extend my great thanks to my advisors, Dr. Frank, Dr. Guo, and Dr. Neshkova. Thank you so much for your time and great patience. Like family members, you always encouraged and motivated me to surmount difficulties that I confronted from the phase of the proposal to the final defense. I will never forget your unique humor, magnanimity, and keen insight.

The author acknowledges the 2016-17 Morris and Anita Broad Research

Fellowship from Steven J. Green School at Florida International University. The financial benefit of the scholarship was helpful for me to polish my dissertation.

Lastly, I am much obligated to the sacrifices of my parents and my wife. Their love, faith, and patience made this tough journey much more bearable.

Any remaining errors and mistakes belong to the author. 
ABSTRACT OF THE DISSERTATION

GOVERNMENT CAPACITY

AND THE ACQUISITION, IMPLEMENTATION, AND IMPACT OF ARRA FUNDS

by

NakHyeok Choi

Florida International University, 2016

Miami, Florida

Professor Howard Frank, Co-Major Professor

Professor Hai Guo, Co-Major Professor

This dissertation examined transportation grants provided to states under the American Recovery and Reinvestment Act of 2009 (ARRA). Some states acquired more grants and utilized them in a timelier manner than others. This dissertation examined why this is the case, utilizing System Theory and Resource Based Theory as the intellectual framework. Human resource and financial resource capacities were viewed as the principal drivers of success and studying this managerially controllable variables underpin the analysis.

Though many studies have examined ARRA since 2009, my dissertation is the first to simultaneously examine the three stages of the ARRA transportation grant process: acquisition, implementation, and impact. There are three research questions, aligned with the three stages: (1) what factors affect state governments in the acquisition of competitive grants? (2) what factors affect state governments in the implementation of competitive and 
formula grants? and (3) what factors affect state governments in expenditure recovery and transportation investment?

Government Capacity consists of four components, namely human resources, financial resources, general management, and experience. I used three regression models (log-linear for the first, and panel corrected standard error for the last two) to test the impact of the government capacity on grant acquisition, implementation, and impact. Overall, the test results showed that three dimensions of government capacity played a significant role to varying extents with respect to ARRA: human resource, financial resource, and experience.

States with higher government capacity [strength (S) of capacity] turned the threat (T) of the Great Recession into an opportunity $(\mathrm{O})$ for the restoration and development of transportation, and compensated for their weakness (W). The dissertation concluded that specific aspects of Government Capacity were thus relevant predictors of the acquisition, implementation, and impact of ARRA grants. Findings also support prior research that quality, not quantity of personnel may of signal import to organizational capacity during times of fiscal stress. 


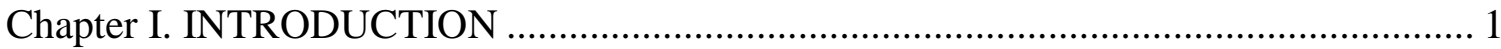

1.1. Motivation of the dissertation ........................................................................ 1

1.2. ARRA and transportation grants .................................................................... 3

1.2.1. ARRA grants ....................................................................................... 3

1.2.2. ARRA transportation grant ………………………………………….... 5

1.3. Schematic Model, research question and hypothesis........................................... 9

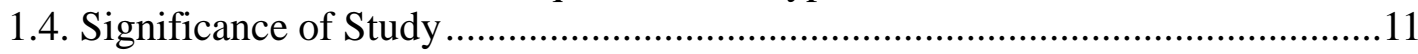

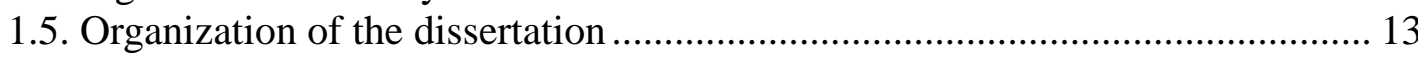

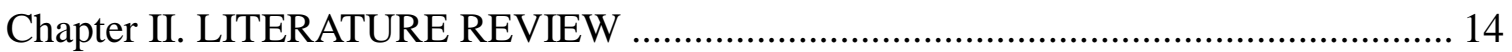

2.1. Literature review on Grant acquisition ........................................................... 14

2.1.1. Government capacity for federal fund attainment .................................. 15

2.1.2. Federal politics.................................................................................... 17

2.2. Literature review on Grant Implementation .................................................. 21

2.2.1. Government capacity and policy implementation ..................................... 21

2.2.2. Government capacity and ARRA implementation................................... 23

2.3. Literature review on Grant Impact and Government Expenditure ..................... 25

2.3.1. Theoretical background of grant impact ................................................... 25

2.3.2. Determinants of government expenditure................................................. 30

2.4. Gaps in literature ........................................................................................... 36

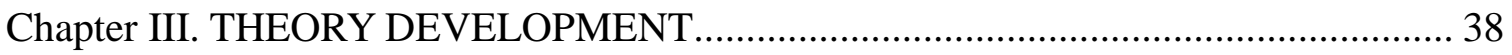

3.1. Theoretical framework.............................................................................. 38

3.1.1. Brief review of Systems theory............................................................ 38

3.1.2. Resource Based Theory ............................................................................ 40

3.1.3. Frame for government capacity and ARRA grant..................................... 43

3.2. Conceptualization and measurement of Government Capacity........................... 44

3.2.1. Literature review of Government Capacity (Capability) .......................... 45

3.2.2. Concept and framework for government capacity................................... 56

3.2.3. Measurement of government capacity in the study ................................. 59

Chapter IV. RESEARCH QUESTION, METHOD, AND DATA ……………………....... 63

4.1. Grant acquisition: Research Question, Method, and Data ................................... 63

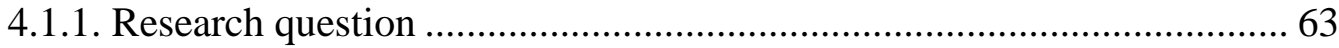

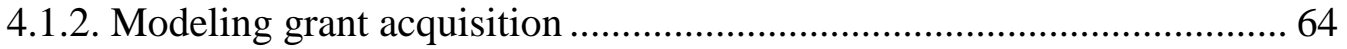

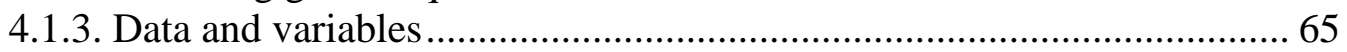


4.2. Grant implementation: Research Question, Method, and Data ......................... 69

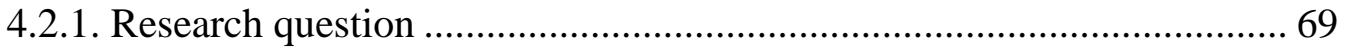

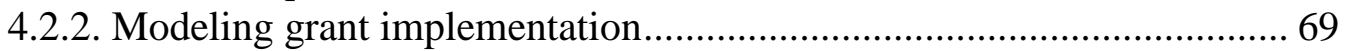

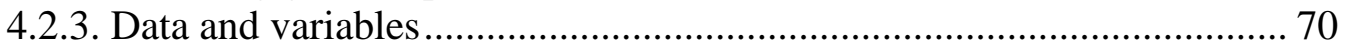

4.3. Grant impact: Research Question, Method, and Data..................................... 75

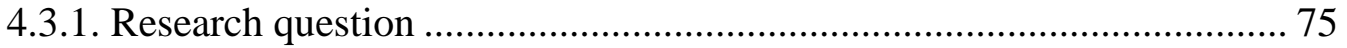

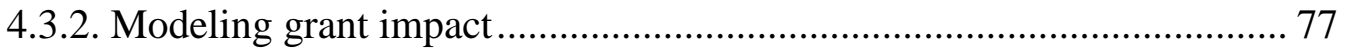

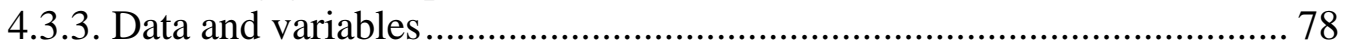

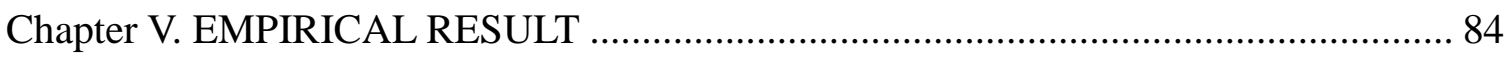

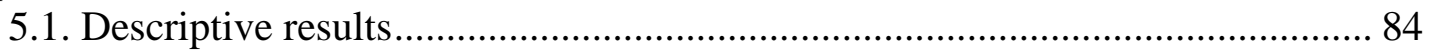

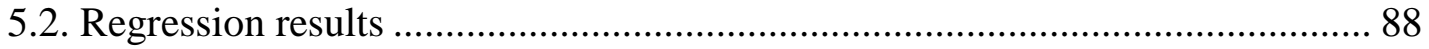

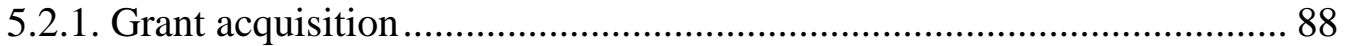

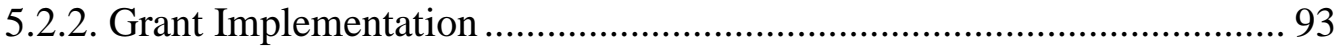

5.2.3. Grant Impact on Government Expenditure......................................... 99

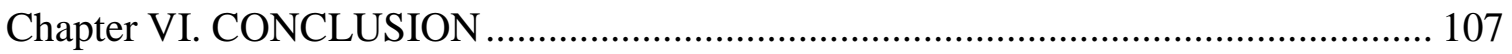

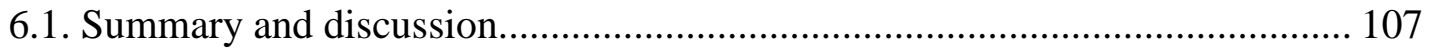

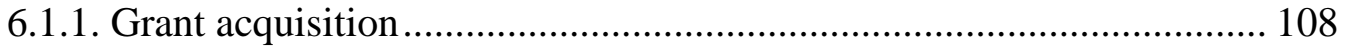

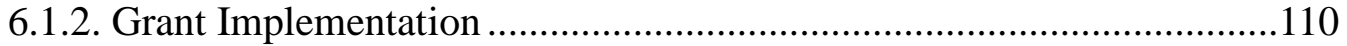

6.1.3. Grant Impact and Government Expenditure .....................................112

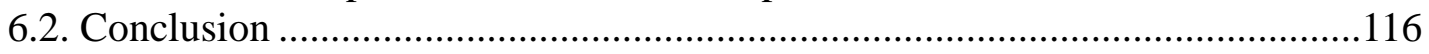

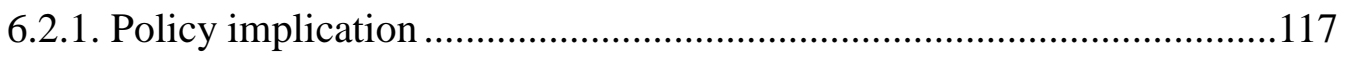

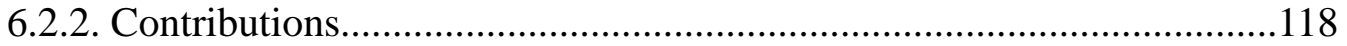

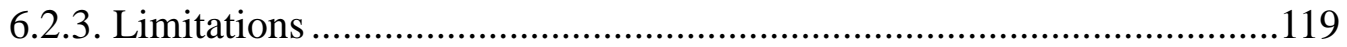

6.2.4. Suggestions for Future Research ................................................ 121

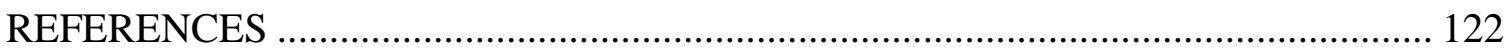

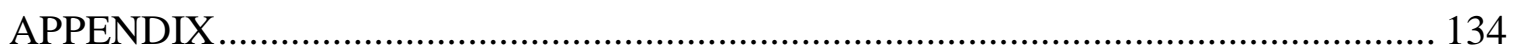

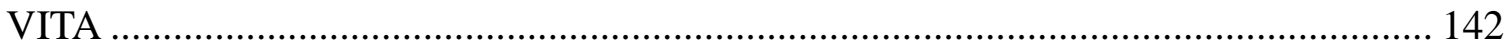




\section{LIST OF TABLES}

TABLE

PAGE

Table 1 Status of Recovery Act Transportation Projects, Obligations, and Expenditures .. 6

Table 2 Literature of ARRA fund and government capacity ....................................... 25

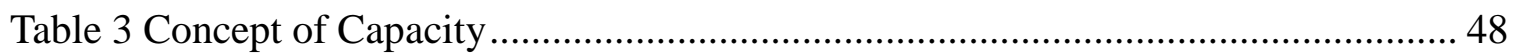

Table 4 Definitions and Measurements of Government Capacity ................................. 50

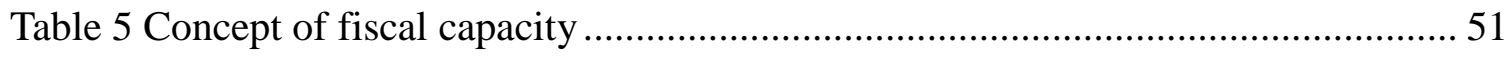

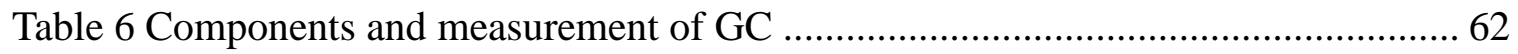

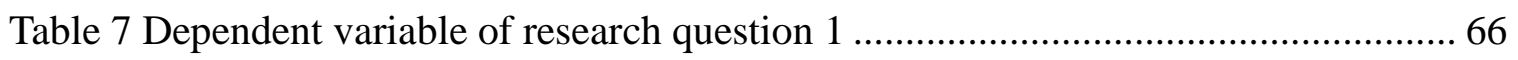

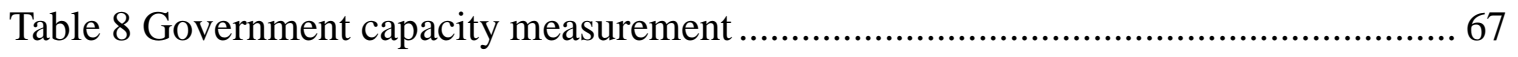

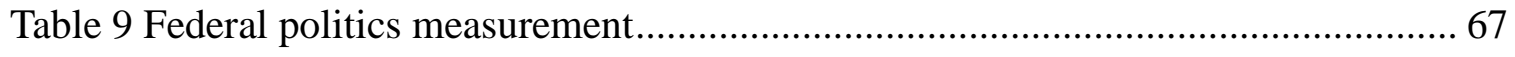

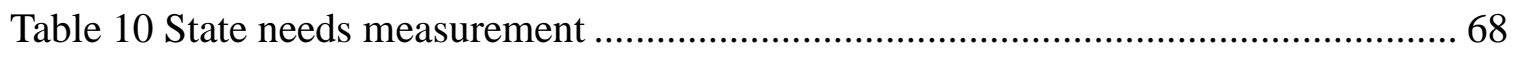

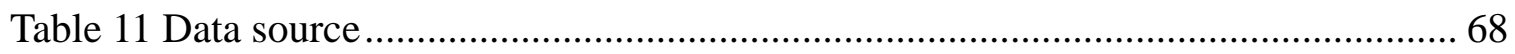

Table 12 Dependent variable of research question 2 .............................................. 71

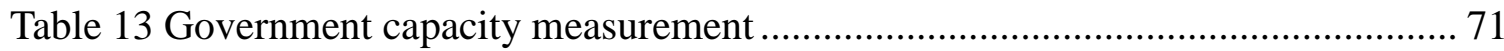

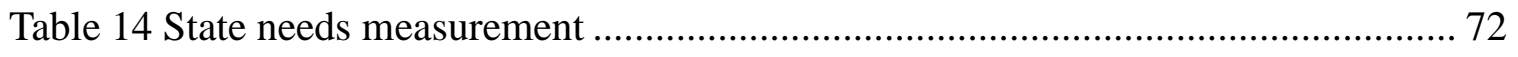

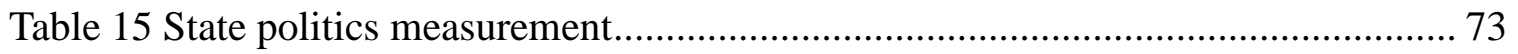

Table 16 Stringency of Tax and Expenditure Limit and of Balanced Budget Requirements ........ 73

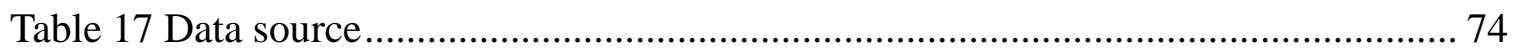

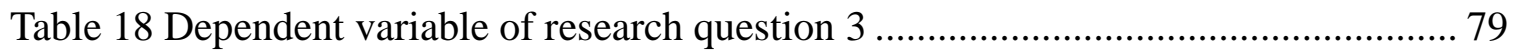

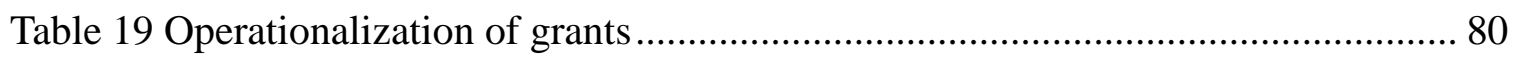

Table 20 Operationalization of relation between state DOT and legislature ................... 82

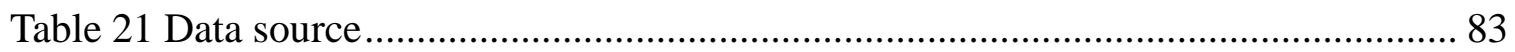




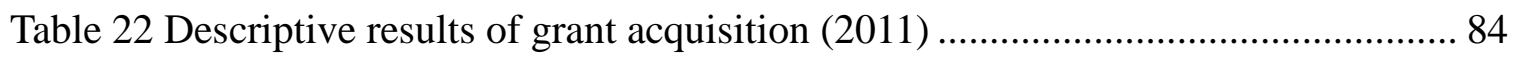

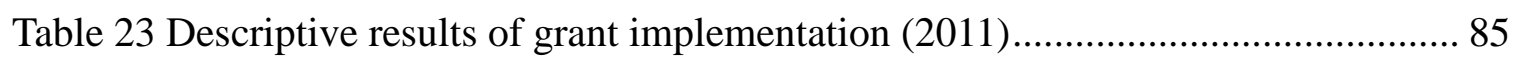

Table 24 Descriptive results of expenditure recovery (per capita \$, 2011) ..................... 86

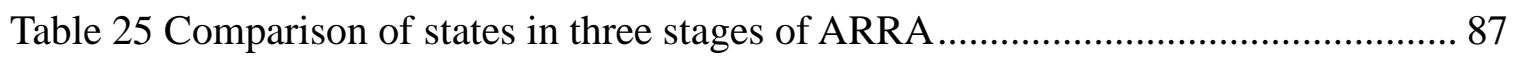

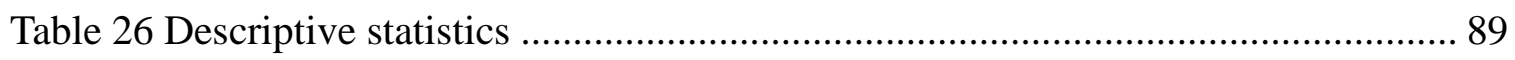

Table 27 Predicting the Effect of Government Capacity on Grant Acquisition................ 91

Table 28 Descriptive statistics on Grant Implementation (2009-2012) .......................... 94

Table 29 Predicting the Effect of Government Capacity on Grant Implementation......... 97

Table 30 Number of states that expand spending ................................................. 100

Table 31 Descriptive statistics on Grant Impact .................................................... 101

Table 32 Predicting the Effect of GC and Grants on Expenditure Recovery ................. 103

Table 33 Predicting the Effect of Government Capacity and Grants on Expenditure .... 105

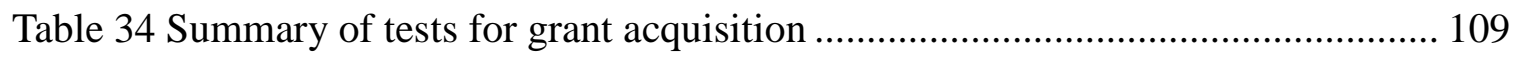

Table 35 Summary of tests for grant implementation...............................................111

Table 36 Summary of tests for grant impact ..........................................................115 


\section{LIST OF FIGURES}

FIGURE

PAGE

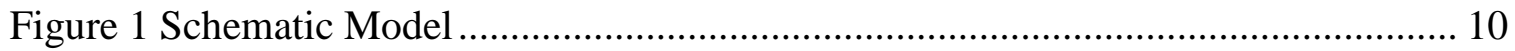

Figure 2. Types of intergovernmental grants. Adapted from Fisher (2007, p. 204)......... 26

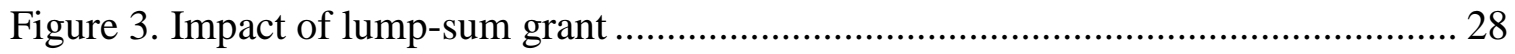

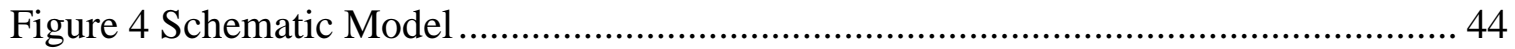

Figure 5. Framework for government capacity................................................... 58

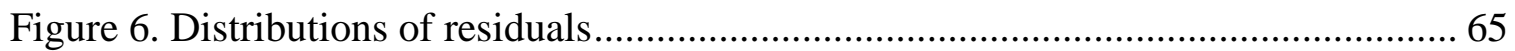

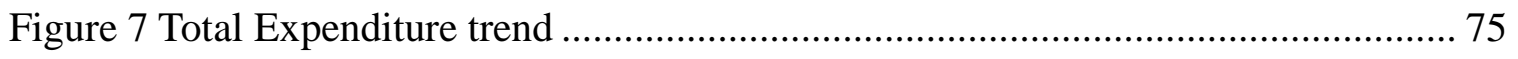

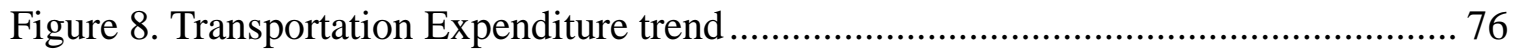




\section{Chapter I. INTRODUCTION}

\subsection{Motivation of the dissertation}

Government Capacity (GC) is a pivotal ability for governments to perform their policy. GC, defined as the ability of government, was characterized as human resource, financial resource, intelligent decision, management, system, etc., according to several studies (Bowman \& Kearney, 1988; Donahue, Selden, \& Ingraham, 2000; Honadle, 1981). Adapting and developing the concept of GC, many descendant studies reported that the performance of government (organization) depends on GC (e.g., Christensen \& Gazley, 2008; Hall, 2008b; Hou \& Moynihan, 2008; Howlett, 2009). These studies argue that governments with more capacity are likely to outperform other governments with less capacity.

As such, the significance of GC seems to be undebatable in the field of public administration. However, there are several points that have not been clearly established. How does GC work in crisis situations? Which components of GC work well (and which do not work well)? Many studies have focused on GC, but few have focused on the role of GC in overcoming crisis. Moreover, although many studies have presented components of GC, few empirical studies have proposed a systemic framework for components of GC.

In these respects, the present dissertation utilizes the most recent economic crisis, the Great Recession (December 2007- June 2009), and the Recovery Act as a U.S. policy, to investigate the role of state government capacity in a crisis. The Recession is an appropriate case for testing state government capacity because it universally impacted all 
states; however, there was variability in recovery across states after the federal policy was enacted.

More specifically, the Recession jeopardized state governments in that states faced considerable and abrupt revenue cuts. The severe fiscal distress threatened the states' abilities to provide core public services and to invest in economic development. However, the American Recovery and Reinvestment Act of 2009 (ARRA), enacted to remedy the serious situation with a stimulus package, helped mitigate the fiscal distress. No state economy was immune to the effects of the Great Recession, and the ARRA simultaneously provided every state with an opportunity for economic relief.

The dissertation examines the aforementioned situation and investigates ARRA grants. Some states acquired more grants and some states implemented grant-funded programs better than others. Additionally, regarding the ARRA objective to recover government expenditure and to increase investment in transportation, this study examines why some states performed better than others in transportation expenditure recovery and transportation investment. This dissertation aims to explain this variability using GC components as independent variables.

In the next sections, I introduce ARRA and the ARRA transportation grants, propose a schematic model and research questions with hypotheses, present the significance of study, and describe the organizational structure of the dissertation. 


\subsection{ARRA and transportation grants}

The present study examines transportation grants from the U.S. Department of Transportation (DOT) under ARRA (also referred to as the Recovery Act). The reason why the dissertation takes ARRA transportation grant as the case of the study is that research on this grant remains scarce. Many studies have examined ARRA in terms of its effects (e.g., Chodorow-Reich, Feiveson, Liscow, \& Woolston, 2012; Cogan, Cwik, Taylor, \& Wieland, 2010; Conley \& Dupor, 2013; Johnson, 2009; Manna \& Ryan, 2011; McGuinn, 2012), but transportation investment—an aim of the Recovery act—has received comparatively scant attention in the research literature. So, it is meaningful to research how ARRA transportation funds were distributed; how the funds were implemented by recipients; and how effective the funds were in transportation expenditure recovery and transportation investment at the recipient level. Before starting the presentation of the research, the next section briefly introduces ARRA and ARRA transportation grant programs to provide background of the case.

\subsubsection{ARRA grants}

The goal of ARRA was to spur economic activity during the Great Recession. Specific aims of the act include job preservation and creation, economic recovery, investment in transportation and infrastructure, and relieving subnational government fiscal stress to provide essential services. To achieve these goals, the federal government distributed funds to states and localities through several grant programs (Wyatt, 2009, p. 128). As of 2009, more than half of the ARRA funds (63\%) were used for Medicaid, 
another $13 \%$ of the funds were allocated to State Fiscal Stabilization Funds, and 24\% of the funds were allocated to other programs (United States Government Accountability Office, 2009). Drawing from the portion (24\%) allocated to other programs, 28 federal agencies provided several grant programs to subnational governments. This dissertation focuses on the grant programs—specifically, the funds distributed by the U.S. Department of Transportation (DOT).

The ARRA grant programs were categorized into two types: a formula based grant and a competitive grant (or a discretionary grant). Competitive grant programs were distributed to recipients at the discretion of each federal agency. Formula grants were allocated by a formula with pre-determined multiple criteria. Competitive grants are useful in that recipient governments can apply for and acquire the grants according to their own plan created to meet their unique needs. However, the grant competition demands significant costs for preparing grant applications, even though the dollar-amounts of these grants are much lower than those of formula grants. For example, a total of $\$ 47$ billion was distributed by the federal DOT to state level recipients under the Recovery act— $\$ 34$ billion was designated for formula and block grants and \$12 billion was designated for discretionary grants. The distributed amount and number of grants vary considerably across the U.S. states. This study distinguishes the two grant programs in the context of an investigation of ARRA grants.

In terms of the impact of ARRA, it has been evaluated as a successful policy. Scheppach (2012) stated that “ARRA was quite effective” because the act was a well-timed intervention compared to most previous fiscal policy. ARRA funds were disbursed to 
"stabilize both the aggregate economy and state spending" in a timely manner. Without the subsidized funds, "states would have had both to cut spending and to increase taxes substantially more" due to the balanced budget rules during the severe period of revenue cutback triggered by the market shock. So, ARRA played a significant role in preventing a pro-cyclical situation and a deeper and longer recession (p. 948).

\subsubsection{ARRA transportation grant}

This dissertation examines transportation grants under ARRA. The term, transportation "comprises the functions of Highways, Air transportation, Parking facilities, Water transport and terminals, and Transit subsidies.” ${ }^{1}$ The Recovery Act describes specific transportation programs of ARRA grants: competitive and formula grants. Competitive grant programs of DOT are (1) Supplemental Discretionary Grants for a National Surface Transportation System, (2) Highway Infrastructure Investment, (3) Grants-in-aid for Airports, (4) Supplemental Grants for Assistance to Small Shipyards, (5) Capital Investment Grants, (6) Capital Assistance for High Speed Rail Corridors and Intercity Passenger Rail Service, and (7) Capital Grants to the National Railroad Passenger Corporation. Formula grant programs of DOT are (1) Fixed Guideway Infrastructure Investment, (2) Transit Capital Assistance, and (3) Highway Infrastructure Investment. A category of the Highway Infrastructure Investment program includes both a competitive and a formula grant.

\footnotetext{
${ }^{1}$ https://www.census.gov/govs/state/definitions.html
} 
Table 1 Status of Recovery Act Transportation Projects, Obligations, and Expenditures

\begin{tabular}{|c|c|c|c|c|c|c|}
\hline \multirow{2}{*}{ Program } & \multicolumn{2}{|c|}{ Number of projects } & \multicolumn{2}{|c|}{$\begin{array}{l}\text { Obligations } \\
\text { (in millions) }\end{array}$} & \multicolumn{2}{|c|}{$\begin{array}{l}\text { Expenditures } \\
\text { (in millions) }\end{array}$} \\
\hline & Awarded & Completed & Amount & $\begin{array}{l}\text { Percent } \\
\text { obligated }\end{array}$ & Amount & $\begin{array}{l}\text { Percent } \\
\text { reimbursed }\end{array}$ \\
\hline \multicolumn{7}{|c|}{ Federal Highway Administration } \\
\hline $\begin{array}{l}\text { Highway } \\
\text { infrastructure } \\
\text { investment }\end{array}$ & 12,931 & 8,124 & $\$ 26,335$ & $99.90 \%$ & $\$ 19,550$ & $74.20 \%$ \\
\hline \multicolumn{7}{|c|}{ Federal Railroad Administration } \\
\hline $\begin{array}{l}\text { High speed } \\
\text { intercity } \\
\text { passenger rail }\end{array}$ & 78 & 0 & 5,671 & 71.1 & 200 & 3.5 \\
\hline Amtrak & 154 & 110 & 1,291 & 100.0 & 1,291 & 100.0 \\
\hline \multicolumn{7}{|c|}{ Federal Transit Administration } \\
\hline $\begin{array}{l}\text { Transit capital } \\
\text { assistance } \\
\text { program } \\
\text { (TCAP) }\end{array}$ & 1,010 & 170 & 7,294 & 100.0 & 4,567 & 62.6 \\
\hline $\begin{array}{l}\text { Fixed } \\
\text { guideway } \\
\text { infrastructure }\end{array}$ & 51 & 24 & 743 & 100.0 & 468 & 63 \\
\hline $\begin{array}{l}\text { Capital } \\
\text { investment } \\
\text { grants }\end{array}$ & 11 & 11 & 743 & 100.0 & 743 & 100.0 \\
\hline \multicolumn{7}{|c|}{ Office of the Secretary of Transportation } \\
\hline TIGER grants & 51 & 0 & 1,482 & 98.8 & 104 & 7.0 \\
\hline \multicolumn{7}{|c|}{ Federal Aviation Administration } \\
\hline $\begin{array}{l}\text { Grants-in-aid } \\
\text { for airports }\end{array}$ & 372 & 365 & 1,086 & 98.9 & 1,055 & 97.1 \\
\hline $\begin{array}{l}\text { FAA facilities } \\
\text { and equipment }\end{array}$ & 399 & 381 & 198 & 99.0 & 143 & 72.2 \\
\hline \multicolumn{7}{|c|}{ Maritime Administration } \\
\hline $\begin{array}{l}\text { Assistance to } \\
\text { small } \\
\text { shipyards }\end{array}$ & 70 & 36 & 98 & 100.0 & 79 & 80.6 \\
\hline Total & 15,127 & 9,221 & 44,941 & 95.0 & 28,200 & 62.7 \\
\hline
\end{tabular}


The Recovery Act, Title XII, states that six federal agencies of DOT operate different kinds of programs. Table 1 above describes detailed information of ARRA transportation grant by agency, regarding transportation projects, obligations, and expenditures. First, the Office of the Secretary distributed \$1.5 billion for Supplemental Discretionary Grants for a National Surface Transportation System, which was used for capital investments in surface transportation infrastructure. Second, the Federal Aviation Administration operates two programs: "Supplemental Funding for Facilities and Equipment” (\$200 million) and “Grants-In-Aid for Airports” (\$1.1 billion). "Supplemental Funding for Facilities and Equipment” is used for necessary investments in the Federal Aviation Administration infrastructure: power systems, air route traffic control centers, air traffic control towers, terminal radar approach control facilities, and navigation and landing equipment. "Grants-In-Aid for Airports" is for installation and commissioning of runway incursion prevention devices and systems at airports. Third, the Federal Highway Administration carries out the "Highway Infrastructure Investment" program, in which $\$ 27.5$ billion was distributed, and the funds were used for highway restoration, repair, construction, and other activities. Fourth, the Federal Railroad Administration managed two programs: "Capital Assistance for High Speed Rail Corridors and Intercity Passenger Rail Service,” with $\$ 8$ billion, supports the development of intercity high speed rail service; and "Capital Grants to the National Railroad Passenger Corporation,” with $\$ 1.3$ billion, was used for the National Railroad Passenger Corporation (Amtrak), for repair, rehabilitation, or upgrade of railroad assets or infrastructure. Fifth, the Federal Transit Administration has three programs, which are "Transit Capital Assistance" ( $\$ 6.9$ billion), 
“Fixed Guideway Infrastructure Investment”2 (\$750 million), and "Capital Investment

Grants” (\$750 million) for additional discretionary programs. Sixth, the Maritime

Administration manages the "Supplemental Grants for Assistance to Small Shipyards"

with \$100 million.

The Recovery Act has a restriction provision for state governments to use DOT

funds. The "Maintenance of Effort” (MOE) provision ${ }^{3}$ regulates states to spend a certain

amount of funds that are from their own sources. If a state fails to meet the MOE, the state

will be restricted from receiving additional funds from DOT in the future. ${ }^{4}$

2 “A 'fixed guideway' refers to any transit service that uses exclusive or controlled rights-of-way or rails, entirely or in part. The term includes heavy rail, commuter rail, light rail, monorail, trolleybus, aerial tramway, inclined plane, cable car, automated guideway transit, ferryboats, that portion of motor bus service operated on exclusive or controlled rights-of-way, and high-occupancy-vehicle (HOV) lanes.” (http://www.transportation.gov/livability/grants-programs\#Fixed Guide Systems)

3 "The Governor of the State shall certify to the Secretary of Transportation that the State will maintain its effort with regard to State funding for the types of projects that are funded by the appropriation. As part of this certification, the Governor shall submit to the Secretary of Transportation a statement identifying the amount of funds the State planned to expend from State sources as of the date of enactment of this Act during the period beginning on the date of enactment of this Act through September 30, 2010, for the types of projects that are funded by the appropriation.” (Sec. 1201. (a), the Recovery Act)

4 "If a State is unable to maintain the level of effort certified pursuant to subsection (a), the State will be prohibited by the Secretary of Transportation from receiving additional limitation pursuant to the redistribution of the limitation on obligations for Federal-aid highway and highway safety construction programs that occurs after August 1 for fiscal year 2011.” (Sec. 1201. (b), the Recovery Act) 


\subsection{Schematic Model, research question and hypothesis}

In this section, I will briefly describe the schematic model to provide the logic flow of the dissertation and present research questions and hypotheses. Detailed explanations of the logic and research questions will follow in Chapters III and IV.

As explained in the motivation section, this dissertation began with the intellectual curiosity of why there was variability among states in terms of grant acquisition, implementation, and impact. To explain the variability, I focus on government capacity (GC), generally regarded as a significant factor for government performance.

Specifically, the purpose of this study is to investigate the three stages of the ARRA grants process: grant acquisition, implementation, and impact. I investigate (1) what affects state governments in the acquisition of competitive grants; (2) what affects state governments in the implementation of competitive and formula grants; and (3) what affects state governments in expenditure recovery and spending.

The major explanatory variable is government capacity (GC), which is expected to play an essential role as an independent variable to explain the three stages of ARRA grants. In addition to GC, several other factors affect the grant process. The schematic model (Figure 1) below depicts the logic flow of this dissertation, specific factors, and the relation between the factors and the explained variables.

The fundamental logic is based on Systems theory; that is, indicating input/throughput decides output. The study regards the three outputs (grant acquisition, implementation and impact) as performance, and the input/throughput factors as the drivers 
of performance. In the model below, the border lines indicate boundaries of the system. Rectangular lines surround the internal system-in which GC, state politics, fiscal institution, and legislative control are explanatory variables for the outputs. Outside of the system, the outputs are also affected by state needs, federal politics, and federal grants. However, compared to internal factors, external factors are too difficult for state governments to manage. In Chapter III, I present specific components of these factors by applying the Resource Based Theory (RBT).

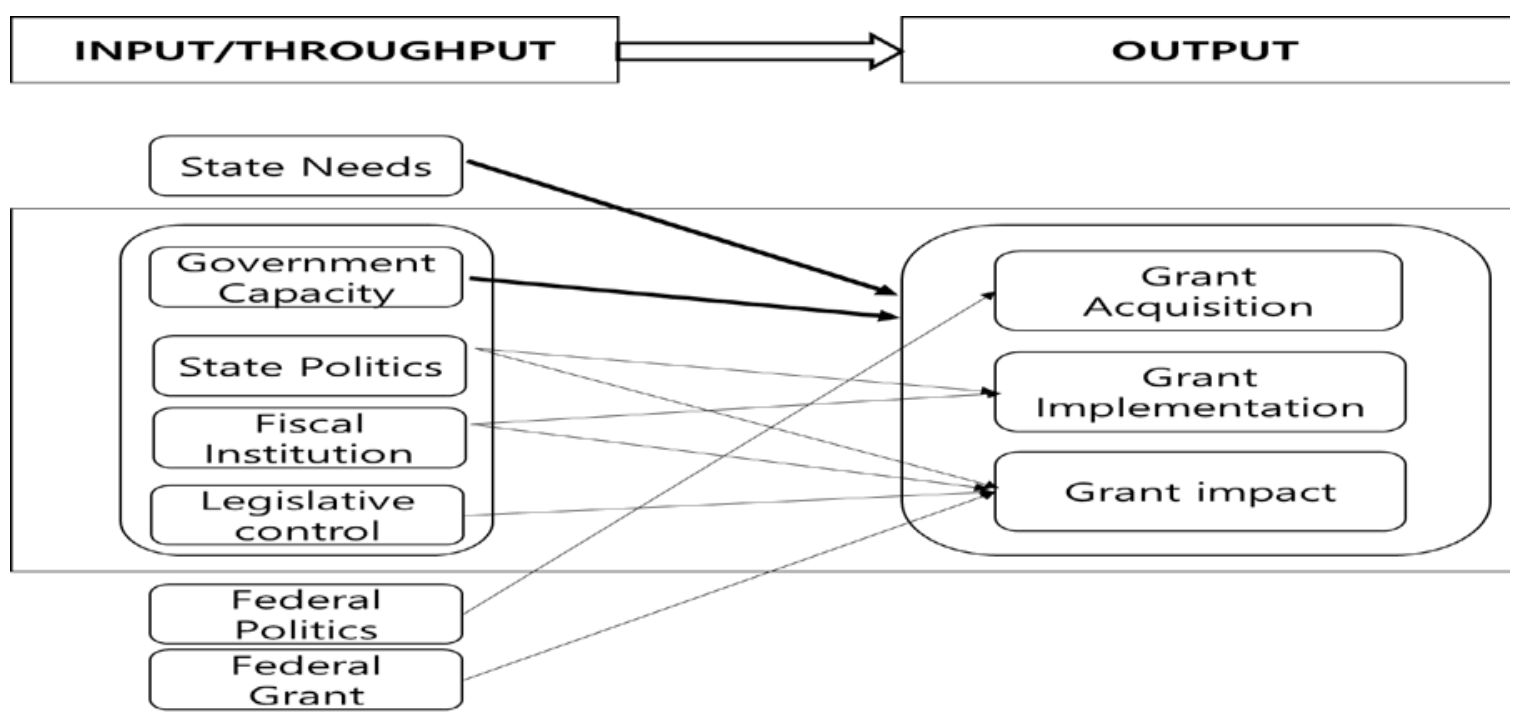

Figure 1 Schematic Model

To investigate the three stage of ARRA transportation grant, I propose three research questions and related hypotheses. Detailed explanations of each rationale per question will be presented in Chapter IV. 
Research question 1: Why do some states receive more ARRA grants than others and to what extent does this depend on government capacity?

Research question 2: Does government capacity affect the implementation of ARRA grants? If so, to what extent?

Research question 3: To what extent did ARRA grant aid affect the transportation expenditure recovery and state transportation investments?

H1. Governments with higher capacity would receive a greater amount of ARRA competitive grants.

H2. Governments with higher capacity would implement a greater proportion of obligated ARRA grants within the first two years.

H3a. ARRA grants will positively affect the transportation expenditure recovery (Recovery impact).

H3b. ARRA grants will impact the transportation investment (Reinvestment impact).

\subsection{Significance of Study}

The dissertation is significant in terms of several contributions to the research literature and to practitioners. First, the study proposes a theoretical framework for the association between government capacity (GC) and performance. Prior literature has mostly sidestepped the theory development of GC, instead depending on practical 
approaches or on authors' intuition and experience. By utilizing Systems Theory and Resource Based Theory (RBT), I devise a framework of logic flow to explain the relation between GC and ARRA transportation grants.

Second, I propose the concept and the measurement of GC based on the theoretical framework. Most prior empirical studies employed a proxy for GC—without suggesting a relevant theory, merely citing other articles. Moreover, some of previous literature avoided theoretical explanations for why their measurement components represent GC. Based on RBT, I propose a framework to capture the concept and the components of GC.

Third, this dissertation is the first study to examine the three stages of ARRA transportation funds: acquisition, implementation, and impact. So far, few studies on ARRA transportation grants have been published, though some policy areas of the ARRA have been studied; for example, energy funds (Carley, Nicholson-Crotty, \& Fisher, 2015; Terman \& Feiock, 2014), education (Nicholson-Crotty \& Staley, 2012), and total funds (Young \& Sobel, 2013). Thus, this dissertation on ARRA transportation grants can also contribute to transportation policy studies.

Lastly, this study suggests several policy implications for practitioners. I provide some evidence of GC's importance in ARRA grant competition and implementation. This is a policy implication for practitioners in that GC is effective even in crisis; individuals and organizations must continue to enhance capacity even during times of calm. Moreover, I find statistically significant evidence concerning the effects of grants on state expenditures - though the effect differed according to the type of grant and to the type of 
expenditure. The results may provide advice on the usefulness of grant type in different types of expenditure.

\subsection{Organization of the dissertation}

The dissertation consists of six chapters. The next chapter presents a comprehensive literature review in three parts-according to the three research questions—and critiques gaps in the literature. Chapter III proposes theory development, in which I present the framework, based on two background theories (Systems Theory and RBT), to explain the link between GC and performance regarding ARRA transportation grants. In addition, the study conceptualizes government capacity by referring to previous literature and presents a framework for the concept and components of GC. Chapter IV describes the three models for the three research questions, in which I present estimation routines and data. Chapter V unpacks the empirical results of the models. Finally, Chapter VI presents a summary of the dissertation, a discussion of the results, and the limitations of the study. 


\section{Chapter II. LITERATURE REVIEW}

Chapter II presents three groups of the research literature reviews, organized into three sections dedicated to grant acquisition, grant implementation, and grant impact. First, a review of the literature on grant acquisition is presented-divided into two groups of studies: the public administration literature focusing on government capacity (GC) and the political science literature focusing on federal politics. Second, several studies are reviewed that focus on the relationship between government capacity and grant (or policy) implementation. The discussion includes research that accounts for how and why GC is important in policy implementation and includes studies that analyze the role of GC specifically in ARRA implementation. Lastly, regarding empirical analysis of grant impact, I present basic economic theories of grant impact on governments and determinants on government expenditure.

\subsection{Literature review on Grant acquisition}

Prior research has provided useful insights into why some governments receive more grant money than others, yet some important factors have not been studied sufficiently. Most political science studies on grant allocation have mainly focused on the effect of political factors on the outcomes of grant cycles. Scholars have examined the federal politics of pork barrel projects (i.e., projects in which government money has been appropriated specifically to bring money to a representative's district)—using the following main explanatory variable: number of congressmen from each state on the relevant committees (e.g., Evans, 1994; Lazarus \& Steigerwalt, 2009; Young \& Sobel, 2013). 
However, the role of subnational governments has been largely neglected, despite their active involvement in the development of grant projects.

The following sections review the public administration literature on government capacity (GC) and the political science literature on federal politics.

\subsubsection{Government capacity for federal fund attainment}

Several public administration studies have focused on the role of government capacity pertaining to grant allocation. The studies argued that level of government capacity affects the acquisition of federal funds. Investigating federalism, Manna and Ryan (2011) asserted that applicants' capacities increase the possibility of winning grant competitions. The authors presented three key factors for operating competitive grant programs: "applicant capacity, applicant need ${ }^{5}$, and politics ${ }^{6}$ " (p. 533). Results of the regression models indicated that government capacity variables had positive effects on submitted applications, and that population and education budget positively affected grant proposal scores. The authors concluded that government capacity is an important variable. Regarding grant acquisition, Johnson (2009, p. 124) asserted that government capacity is important to the search for eligible grants and the application preparation process. Johnson reported that staffs of low capacity municipalities spent significant time just to determine

\footnotetext{
${ }^{5}$ The variable, states' 'need' was measured by the percentage cut to the state education budget and poverty rate.

${ }^{6}$ The variable, 'politics,' was operationalized as the party affiliation of the governor, with the expectation that Republican governors are less likely to seek federal money.
} 
whether or not their governments were eligible to apply for a competitive grant. It implies government capacity (or capability) would play an essential role in the preparation of application and in the achievement of the grant. Collins and Gerber (2008) compared government capacity and local needs to determine which factor was more important in predicting fund allocation. Using data analysis, they asserted that higher administrative capacity was “a consistent driver of funding allocation” (p. 1137).

What can be a rationale about why government capacity (GC) is significant on grant application and allocation? Some scholars have suggested that GC is a good means by which grantors can screen out disqualified applicants and also a good point for grantees to induce grantors' decision. Terman and Feiock (2014) asserted that "grantors use capacity as one means to discriminate between governments that are more or less likely to succeed in carrying out the goals of the grant” (p. 6). Moreover, Collins and Gerber (2008) presented their rationales for why higher level of administrative capacity is critical to grant procurement, focusing specifically on search costs and monitoring costs. Grantors aim to fund successful programs; grantors should mitigate their risks of selecting applicants with a higher likelihood of failure in implementing grant programs. Thus, for grantors who assume that grantees with higher capacity are more likely to succeed in implementing the grant programs, administrative capacity—which is reflected by "the professionalism and complexity" - is a "heuristic to reduce search costs," which incentivizes grantors to select higher capacity applicants (pp. 1131-1132). 


\subsubsection{Federal politics}

The political science literature in this area of research has focused on the federal politics that pertain to grant allocation. In these studies, the main assumption is that the distributive policy is decided by pork barrel politics—-politicians try to secure funds for their political interests [e.g., political (electoral) support for their districts]. In these studies, typical political variables are: Congressional members from each state that serve on relevant committees (e.g., Evans, 1994; Lazarus \& Steigerwalt, 2009; Young \& Sobel, 2013), average tenure-length of Congressional members from each state (Young \& Sobel, 2013), Senate over-representation (Hauk Jr \& Wacziarg, 2007; Larcinese, Rizzo, \& Testa, 2013; Lauderdale, 2008), composition of party affiliation in Congress (Balla, Lawrence, Maltzman, \& Sigelman, 2002; Levitt \& Snyder, 1995), and presidential partisanship or support to the president (C. R. Berry, Burden, \& Howell, 2010; Young \& Sobel, 2013). This section introduces examples from the political science research literature.

Young and Sobel (2013) examined ARRA funds given to 50 states and the determinants that affected ARRA fund allocation from the federal government and the U.S. Congress. Using four different groups of independent variables-Keynesian determinants of countercyclical policy ${ }^{7}$, Congressional power and dominance ${ }^{8}$, Presidential electoral

\footnotetext{
7 Keynesian determinants of countercyclical policy are unemployment rate and change, state tax revenue growth, level and growth change of real state per-capita GDP, marginal propensity to consume in state (MPC).

${ }^{8}$ Political variables include federal grants and payments to state \& local governmnts (FEDAID), FEDAID/federal revenue, average tenure-length of state's representatives and senators, number of state prepresentatives sitting on the appropriations committee in the House and Senate, and Democrats (or Republicans) on the appropriations committee. The authors also added: the funds for four departments (Department of Health and Human Services, Department of Education, Department of Transportation, and Department of Energy), total members and each party's members sitting on the House and Senate
} 
vote maximization ${ }^{9}$, and demographic variables - the authors tested whether the independent variables affected total ARRA spending and the four departments' funds, which were divided into "funds announced and funds made available ${ }^{10}$." Analysis of the 2009 data revealed that federal money received in the previous year was important to acquire ARRA funds. Tenure of House members had positive effects on total ARRA fund allocation, but Tenure of Senate members had negative effects. States that Barrack Obama won in 2008 were likely to receive ARRA funds rather than other states. Moreover, Democratic members of committees and subcommittees significantly affected fund allocation to their states. Their study provides a comprehensive approach to test ARRA fund allocation with multiple dimensions of explanation: economic conditions, presidential effects, and congressional effects.

Larcinese et al. (2013) studied the effects of population dynamics on the allocation of federal budget. Criticizing previous literature that used state size (population) as an explanatory variable for variations in federal money allocations, the authors divided the

appropriations and authorization subcommittees, and total members and each party's members on the authorization subcommittee of the House.

${ }^{9}$ One of the variable groups is the electoral importance measure $(\mathrm{Y})$, measured by $\mathrm{Y}=1-4 \times$ $(X-0.5)^{2}$, where $X$ means \% of a state's popular vote won by Barrack Obama in 2008. The other one is a dummy, with a value of 1 if Obama won the state in 2008.

${ }^{10}$ (1) Funds Announced by an agency means "Funds that have been publicly announced as available to entities outside of the federal government. Not all available funds are announced publicly. For example, the funds going to a project started prior to the Recovery Act that are commingled with the project's Recovery funds will not be announced publicly before being made available to a recipient). The Funds Announced figure should not be viewed as the total funding that an agency has made available." (2) Funds Awarded (Obligated by the federal agency) to a Recipient means "Funds that have been made available to a recipient." (3) Funds Paid Out (Gross Outlay) by an Agency means "Funds that a federal agency has paid out to a recipient." http://www.recovery.gov/arra/FAQ/Pages/glossaryHome.aspx 
population effects into slow- and fast-growing, and stressed that the most important factor was speed of growth rather than an absolute size of a state. They used outlays data of federal budgets from 1978-2002, and adopted regression models, such as OLS and fixed effects. Their independent variables were Senators per capita that implies Senate overrepresentation ${ }^{11}$, State population, and Population index ${ }^{12}$. Other control variables were socio-economic variables ${ }^{13}$. The authors concluded that small population size was important in federal budget allocation, but slow population dynamics was more important than the size of a state. More specifically, a fast-growing small state was likely to lose federal money compared to a slow-growing large state (p. 279). In addition, among six categories ${ }^{14}$ of dependent variable, Senators per capita had a positive effect on grant allocation without the population index variable, but had no significant effect with the population index variable that had a negative sign for allocation.

Gimpel, Lee, and Thorpe (2012) investigated reasons why the ARRA funds were not distributed to economically disadvantaged counties. To explain the reasons, the authors adopted two models: Policy Windows and Pork Barrel. From the rationale of the Policy Windows model, preexisting policy goals (e.g., energy, health care technology, infrastructure and education) were occasionally coupled with issues that the ARRA aimed

\footnotetext{
11 Senator per capita is 2/population, and the over-representation index is (2/state population)/(96/US population) $=\mathrm{US}$ population $/ 48 *$ state population).

12 Population Index = Each year's population/ base year (1978)’s population

13 Socioeconomic variables include income, unemployment, \% aged above 65 , \% within schooling age (5-17)

14 The dependent variable is measured as total federal spending, direct payments to individuals, grants, salaries, defense expenditure, and federal spending on except defense.
} 
to address (which were triggered by the Great Recession). The funds were allocated to pursue those shared goals as long as grantees did not deviate from the aims of the Recovery Act. The authors ultimately showed, via the results of their quantitative analysis (OLS) which used expenditure data of total ARRA funds and infrastructure spending - that variables of the Policy Windows model ${ }^{15}$ explained much more of the ARRA funds than variables of the Pork Barrel model ${ }^{16}$.

Rich (1989) researched determinants of federal grant allocation. After reviewing theories of Political-Business Cycles, Pork Barrel Politics, Bureaucratic Politics ${ }^{17}$, and Grantsmanship, he criticized that prior literature oversimplified the determinants as only political variables. For example, the Political-Business Cycle model explains that governments expand their spending during the period encompassing national elections. He said that the model does not sufficiently explain grant allocation, because Congress must legislate a grant program's creation and the modification of rules for grant programs, and because the President must also persuade Congress into agreement with his policy change. Moreover, the Pork Barrel Politics model explains "the norms of universalism and

\footnotetext{
${ }^{15}$ Variables for the Policy Window model were National Institutes of Health, National Parks, Number of airports, Interstate mileage, U.S. highway mileage, Water area, Number of PhDs granted by local universities, \% Employed in computing and science, \% Employed in health and social services, and \% Employed in state and local government

16 Variables for the Pork Barrel model were Counties represented by a committee of House Transportation member, Appropriations, and Energy and Commerce member; Counties represented by a committee of Senate Environment and Public Works and Appropriations member; Total members of House serving county; \% Democratic House members serving county; \% Democratic senators serving county; and \% Democratic presidential vote 2008

17 "Bureaucrats allocate expenditures both in gratitude for past support and in hopes of future congressional support; and congressmen support agencies both because they owe them for past allocations and because they desire future allocations" (Arnold 1979, p. 36 as cited in Rich 1989, p. 196).
} 
reciprocity” with congressmen's political interests, which induce the allocation of funds to programs that impact a broad number of districts. However, according to Rich, the work of Congress primarily concerns agreement with “overall program authorization,” except for a few programs, and most substantial decision making is conducted by bureaucrats. Thus, he argued for a comprehensive approach, encompassing "political influence, community needs, and local demand and administrative capacity.” From the regression results, local demands, prior experience on a grant program, local needs ${ }^{18}$, and House members variable had positive effects on the amount of federal aid awarded.

\subsection{Literature review on Grant Implementation}

\subsubsection{Government capacity and policy implementation}

Various prior studies have emphasized that government (or organizational) capacity (GC) plays an essential role in policy implementation success for recipient governments (e.g., Carley et al., 2015; Hou, Moynihan, \& Ingraham, 2003; McDermott, 2006). Fredericksen and London (2000) explained that organizational capacity to implement a policy is a fundamental factor in the decision-making of agencies that allocate funds to recipients. They also asserted that the success in policy implementation depends on the capacity of the grantee or the contractee. McGuire, Rubin, Agranoff, and Richards (1994) stated, citing a couple of articles (Mead, 1986; Sokolow, 1989), small communities

\footnotetext{
${ }^{18}$ Local needs were measured by population change, employment change, per capita income change, unemployment, poverty, among others.
} 
are "less well off" and lack organizational and managerial capacity, so these communities are less likely to have adequate abilities to implement development projects (p. 426). Honadle (1981) suggested that the definition of capacity comprises several dimensions ${ }^{19}$, and she indicated that capacity is the ability to "develop programs to implement policy" (p. 577). Hou et al. (2003) examined management capacity, by adopting their research project, the Government Performance Project (GPP). They proposed five management systems— "financial management, capital management, human resources management, information technology, and managing for results" — and suggested that the five components "act as enablers to policy implementation” (p. 297). Collins and Gerber (2006) suggested a postulate regarding the relation between capacity and implementation. They stated, “...local governments with greater capacity are more likely to implement programs that comply with state and federal regulations” (p. 618). McGuinn (2012) insisted that insufficient capacity and political constraints would hinder the policy implementation of governments (p.147), while Gamkhar and Pickerill (2012) similarly argued that “fiscal and institutional capacity constraints at the state and local levels have become real obstacles to sustaining meaningful reform.”

In an investigation of education policy, McDermott (2006) presented the case study of Massachusetts education reform and stressed the importance of government capacity. Aside from the other two factors for success (i.e., incentive structure and trust) in the implementation of education reform, lack of government capacity is the critical point

\footnotetext{
19 The dimensions include the ability: to anticipate and influence change; make informed, intelligent decisions about policy; develop programs to implement policy; attract and absorb resources; manage resources; and evaluate current activities to guide future actions.
} 
that can hinder policy implementation. For example, McDermott asserted that "insufficient administrative capacity hindered use of sanctions and also limited the state Department of Education's ability to provide assistance for underperforming schools and districts” (p.51). The necessary condition for government capacity encompasses human and financial resources, even though governments do not have fully sufficient resorces (p. 54).

\subsubsection{Government capacity and ARRA implementation}

Researchers have examined the effect of GC on the implementation of the ARRA program. Carley et al. (2015) examined whether or not federal guidance and state capacity affect a state's speedy spending of ARRA energy funds. They set the dependent variable as the percentage of actual expenditures of obligated ARRA energy funds—in which a higher percentage indicates that a state spent the energy funds rapidly (or efficiently) to meet an objective of the Recovery Act. Using a fractional logit model, the authors found that government capacity ${ }^{20}$ and guidance were positively associated with spending of ARRA funds.

Terman and Feiock (2014) investigated factors affecting outcomes that were measured by the delay of implementation. Using their own survey data on the Energy Efficiency and Conservation Block Grant (EECBG) Program, the authors tested the involvement of the city council and the mayor and government capacity, with other control

\footnotetext{
${ }^{20}$ It is measured with "some combination of relevant technical skills, the existence and leveraging of relevant organizational experiences, adequate resources, the cognitive skills necessary to learn and adapt, and human capital or adequate personnel resources” (p. 116).
} 
variables. Among the five variables, only the lack of staff capacity was statistically significant and negatively affected the implementation delay. The authors interpreted that negative effects were produced because governments "self-select into project types where less staff capacity is necessary” (p. 18). Terman and Feiock (2015) studied municipalities’ perception of the ARRA program (EECBG) time rules, which require recipient governments to implement ARRA projects in a timely manner. Though their key independent variables were the use of third-party implementers (e.g., contractors), the authors employed government capacities as control variables (i.e., administrative capacity, policy capacity, and management structure). The results of their ordered logit regression indicated that policy capacity had negative effects, which means a higher capacity government is less likely to suffer from the time rule. However, the management structure variable had positive effects, which implies a council-manager form of government would be in a disadvantaged position to overcome the time rule.

Table 2 provides the summary of studies that I reviewed above. It shows the measurement of GC, dependent variables, research method, data, and effects of GC on dependent variables. 
Table 2 Literature of ARRA fund and government capacity

\begin{tabular}{|c|c|c|c|c|}
\hline Studies & Capacity & Dependent Var. & Method & Effects \\
\hline $\begin{array}{l}\text { Carley et } \\
\text { al. (2015) }\end{array}$ & $\begin{array}{l}\text { Government } \\
\text { relevant } \\
\text { experience, } \\
\text { financial } \\
\text { management } \\
\text { capacity }\end{array}$ & $\begin{array}{l}\text { ARRA energy fund } \\
\text { spending }\end{array}$ & $\begin{array}{l}\text { Fractional } \\
\text { logit, } \\
\text { Generalized } \\
\text { linear }\end{array}$ & + \\
\hline $\begin{array}{l}\text { Terman } \\
\text { and Feiock } \\
\text { (2015) }\end{array}$ & $\begin{array}{l}\text { Administrative } \\
\text { capacity, } \\
\text { Policy } \\
\text { capacity, } \\
\text { Management } \\
\text { structure }\end{array}$ & $\begin{array}{l}\text { Energy Efficiency } \\
\text { and Conservation } \\
\text { Block Grant } \\
\text { (EECBG), } \\
\text { Perception on rules } \\
\text { of time limits as an } \\
\text { obstacle }\end{array}$ & $\begin{array}{l}\text { Ordinal } \\
\text { logit }\end{array}$ & $\begin{array}{l}\text { Policy } \\
\text { capacity (-), } \\
\text { Management } \\
\text { structure (+) }\end{array}$ \\
\hline $\begin{array}{l}\text { Terman } \\
\text { and Feiock } \\
\text { (2014) }\end{array}$ & $\begin{array}{l}\text { Overall } \\
\text { capacity, } \\
\text { Managerial } \\
\text { capacity, } \\
\text { Dedicated } \\
\text { sustainability } \\
\text { staffing, } \\
\text { lack of staff } \\
\text { capacity, } \\
\text { lack } \\
\text { information } \\
\text { resource }\end{array}$ & $\begin{array}{l}\text { deviation in days of } \\
\text { delay for project } \\
\text { from the average } \\
\text { number of days of } \\
\text { delay }\end{array}$ & $\begin{array}{l}\text { Hierarchical } \\
\text { cross-level } \\
\text { random } \\
\text { effects } \\
\text { model }\end{array}$ & $\begin{array}{l}\text { Lack of staff } \\
\text { capacity (-) }\end{array}$ \\
\hline
\end{tabular}

\subsection{Literature review on Grant Impact and Government Expenditure}

\subsubsection{Theoretical background of grant impact}

Before discussing grant impact, we must first identify how to classify types of intergovernmental grants. Figure 2 presents the way of grant typology with four criteria: the condition on use, the method of grant allocation, whether or not a grant requires matching funds, and the limit of grant size. 


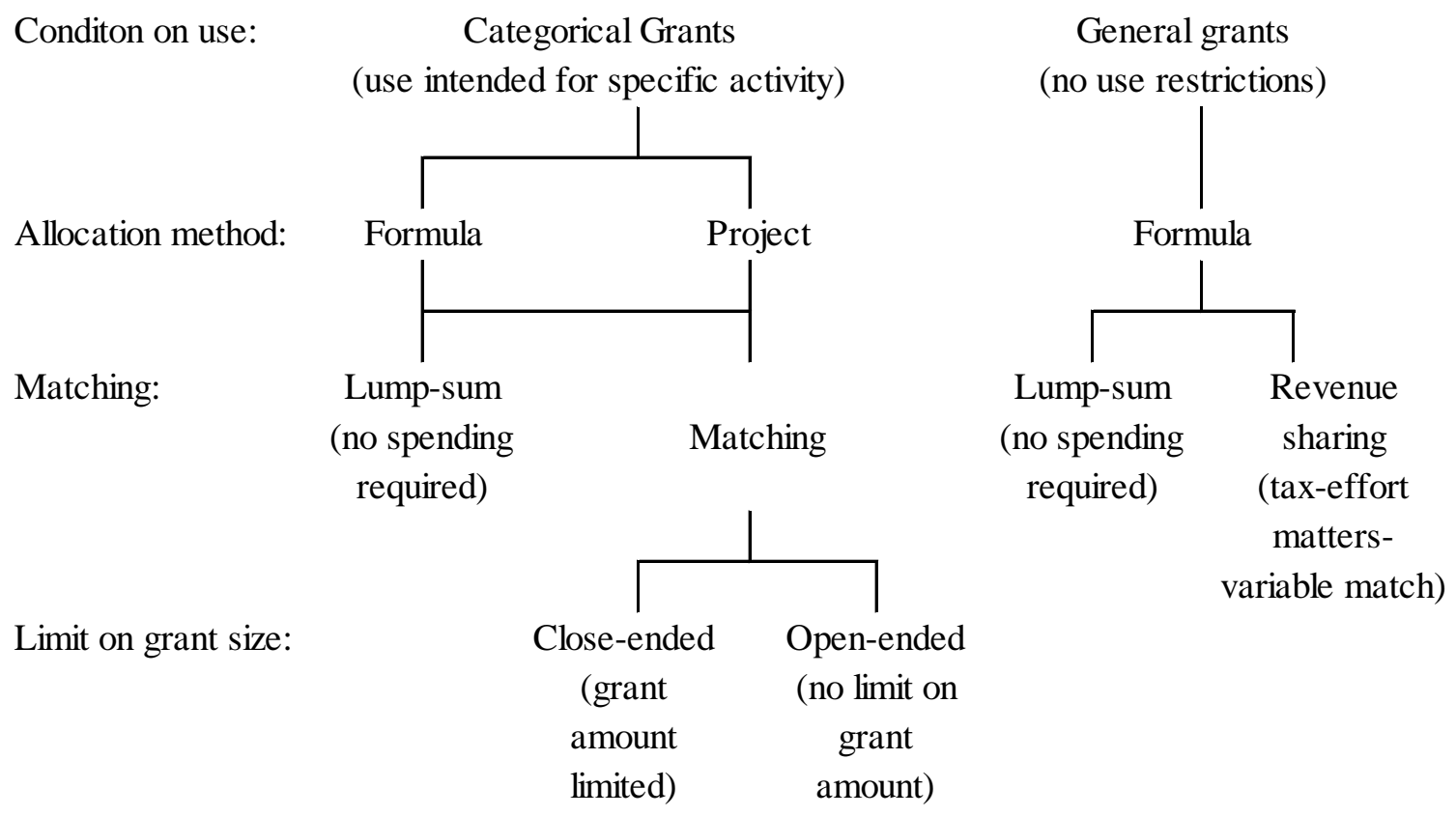

Figure 2. Types of intergovernmental grants. Adapted from Fisher (2007, p. 204)

First, according to the conditions of use, we can distinguish general grants and categorical grants. "Federal intergovernmental grants to state government all are categorical grants” (Fisher \& Bristle, 2012, p. 224); ARRA grants—which are instances of states spending federal grant funds-have restrictions on their use. Second, we can distinguish between method of allocation: formula and project grants. As described above, ARRA includes both methods of allocation. Formula grants were allocated according to preset criteria, and project grants were distributed by the competition-based method. Third, grants can be categorized as matching or non-matching. If the amount of grant changes when a recipient government changes taxes or expenditures, the grant is called a matching grant. Otherwise, the grant is referred to as a lump-sum or non-matching grant (R.C. Fisher, 2007, p. 204). ARRA grants were structured as one-time aid; recipients' requirement to match spending was waived, so these were lump-sum grants. Lastly, matching grants can 
be considered closed-ended or open-ended—depending on whether a limit has been placed on the grant amount.

Let us now examine grant impact. Economic theories have suggested that “matching grants are more stimulative than lump-sum grants" (R.C. Fisher, 2007, p. 207). This is due to the size of price effect, which is caused by matching grants. The size of price effect is greater than the one of income effect that lump-sum grants generate. If ARRA grants had been designed to be matching grants, state spending might have been much greater than the real effects. However, given the severe and urgent situation produced by the Great Recession, a prompt counter-cyclical fiscal policy was needed, so perhaps lumpsum grants were indeed the most appropriate grant-type for the ARRA program.

Figure 3 presents the effect of lump-sum grants that has a specific purpose of spending. Let's assume that a recipient government currently consumes $\mathrm{X}$ at $x_{0}$ under the initial budget line $(\mathrm{AB})$. If the recipient government receives intergovernmental grants $(G)$, it shifts the initial budget line $(A B)$ to $A_{C D}^{21}$. Albeit granters expect recipients would increase their spending on $\mathrm{X}$ as much as the amount of grant, there is a possibility that the recipient decides to consume a lower level of $\mathrm{X}$ at $x_{1} \cdot{ }^{22}$ This is called fungibility which means a recipient diverts the funds that would have been spent on a specific purpose to another purpose in the overall budget, because the recipient saves the substantial amount of the fund after being subsidized by the grant. That is, if fungibility happens, a recipient

\footnotetext{
${ }^{21}$ If the grant does not have the restriction, the second budget line should be FD.

$22 \overline{x_{0} x_{1}}$ is smaller than $\mathrm{G}$
} 
government increases the total amount of spending by less than the amount of grant that grantors expected. The categorical lump-sum grant "does not guarantee that expenditures on the aided category will increase by the full amount of the grant” (Fisher, 2007, p. 211).

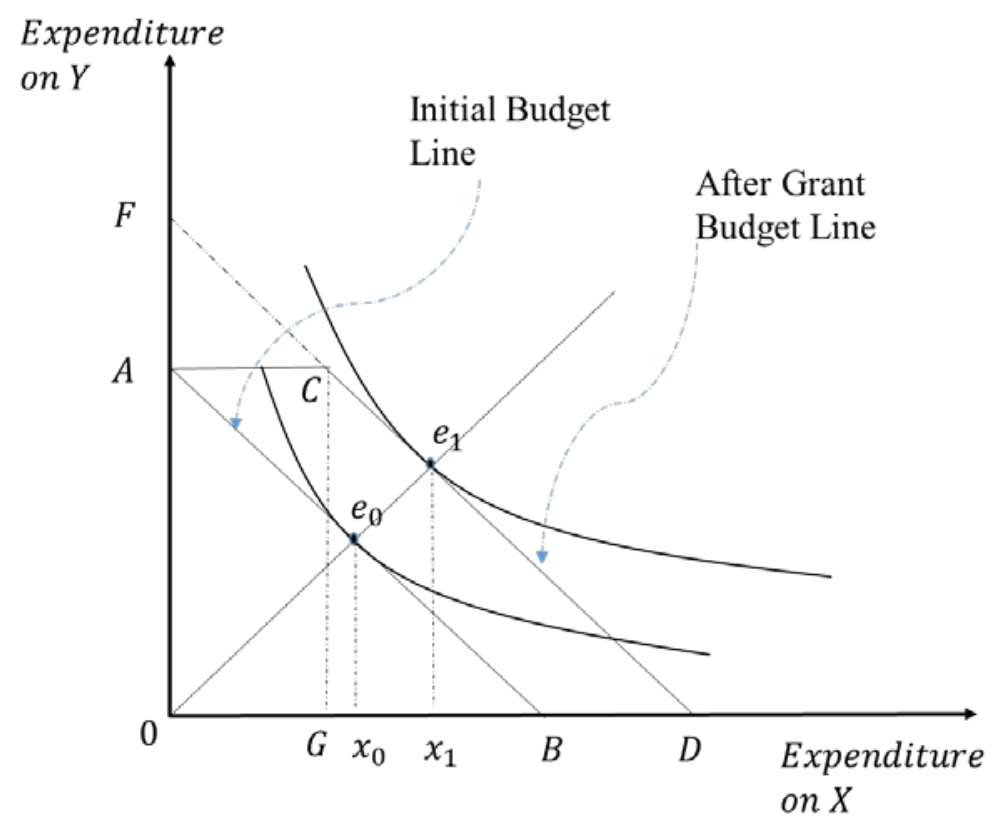

Figure 3. Impact of lump-sum grant

The issue of fungibility represents much to the impact ARRA grants had on state government expenditures since the Great Recession. Some studies have suggested that federal aid has crowding-out effects (i.e., federal aid triggers declines in state spending). For example, Knight (2002) asserted that grant awards had negative effects on state spending—based on his two-stage least squares model analyzing the federal highway grants. However, most studies assert a positive relationship between federal grants and subnational government expenditure. The positive relationship is supported by the flypaper 
effect. A lump-sum grant is known that its effect on increases in expenditure is greater than income's effect, which is called the flypaper effect (Fisher, 2007, p. 218). According to the economics of public finance, federal grants shift the budget line to the right, and, consequently, the government would spend a greater quantity of money. For instance, concerning the flypaper effect, Nesbit and Kreft (2009) analyzed the effect of a \$1 increase in the federal grant on state highway spending. After reviewing previous literature that showed the positive effects on state expenditure, the authors presented results of their analysis-indicating similar effects. This refutes the argument that federal grants have crowding-out effects and indicates that flypaper effects are being produced.

The purpose of a federal grant is not to "supplant" subnational government spending but to "supplement" it (CONGRESSIONAL BUDGET OFFICE, 2011). So, many federal grants are accompanied by a maintenance-of-effort (MOE) provision to induce subnational governments to spend their own money on the grant program, thereby preventing them from spending their money on their priorities. However, the degree of impact on government spending increase is not clear (CONGRESSIONAL BUDGET OFFICE, 2011), and one study suggested that federal grants have a crowding-out effect on state government spending. Thus, the present dissertation examines if ARRA grants had stimulative effects on state government expenditures, and if so, determines the degree of these grant effects. 


\subsubsection{Determinants of government expenditure}

This section presents a literature review on determinants of recipient government expenditures - to find implication that can be applied in the examination of grant impact on expenditure. Factors affecting government expenditure are categorized into political, fiscal (institutional), and external factors of government. First, in terms of political determinants of expenditures, the literature generally states that the Republicans are more likely to have a balanced budget (Hou \& Smith, 2010), whereas Democrats tend to have higher demands on spending (Alt \& Lowry, 1994). Second, another determinant, legal limitations [e.g., tax and expenditure limitation (TELs)], hinder governments from raising taxes (revenues) or expenditures (Amiel, Deller, \& Stallmann, 2009; Deller, Stallmann, \& Amiel, 2012; Mullins \& Wallin, 2004). Third, external factors affect government expenditure: median income from the median voter theorem (Congleton \& Bennett, 1995; Mueller, 2003, p. 244) and the unemployment rate from the business cycle hypothesis (e.g., Hou \& Smith, 2010; McGranahan, 1999).

\section{Political factors for expenditures}

Though the administrative body participates in policy formulation, the main actors of policy decision-making process are politicians in the representative democracy system. Due to the properties of budgeting that reflect government policies, political factors are essential to analyze public finance and budget issues. In addition, political variables are needed to analyze infrastructure finance, because infrastructure investments extend across long time periods, compared to the short time periods of politicians' terms, which may 
cause politicians to transfer current fiscal responsibility to future generations (W. Wang, Hou, \& Duncome, 2007, p. 26). Thus, the first determinants of government expenditure are political factors.

It is generally known that Democrats are high-demand parties on spending, compared to Republicans. However, there is not enough evidence to support this anecdote. Poterba (1995b) suggested that state legislatures with a Republican controlled lower-house and a Democratic controlled upper-house (i.e., State Senate) tended to have above-average spending; however, states with the reverse political party configuration in their legislature tended to have below-average spending. While redistributive expenditures are differentially affected by the respective ideologies of the U.S. political parties, it remains unclear if developmental spending is affected by these different ideologies. Thus, we must examine the effect of political differences on transportation investments as the developmental policy.

\section{Fiscal institutions for expenditure}

Concerning the impact of fiscal institutions, tax and expenditure limitations (TELs) and balanced budget requirements (BBRs) have been mainly discussed in the research literature. Most states place legal limitations on governments that hinder them from raising taxes (revenues) or expenditures (Amiel et al., 2009; Deller et al., 2012; Mullins \& Wallin, 2004). In one study, Hou and Smith (2010) reported that expenditure limitation rules had a positive relation with fund balance, but tax limitation had a negative association with fund balance. Amiel et al. (2009) constructed a stringency index of TELs with 28 weighted 
criteria. They proposed six groups of 28 criteria $^{23}$ (p. 6). Higher aggregated value of the components indicates higher level of stringency of TELs. In the present study, I adopt the stringent index of TELs as a fiscal institution variable in the quantitative analysis.

The second fiscal institution is the balanced budget requirement (hereafter BBR). BBRs do not directly affect transportation expenditure. BBRs "usually apply to operating budgets and not capital or pension funds. Within current expenditure, they cover general funds and not federal funds or special funds dedicated to specific purpose such as local governments or transportation. As a result, BBRs typically apply to less than 75 percent of state budgets” (Gordon, 2012, p. 249). However, BBRs could affect transportation expenditure indirectly, because transportation expenditures are allocated partially from general funds, and budget allocations for other categories would also affect transportation.

BBRs exist in three different forms (NCSL, 2010, p. 2): (1) the budget proposal should be submitted with a balanced budget; (2) the "enacted budget" also should be balanced; and (3) deficit carryover is not allowed. Though most states have rules pertaining to BBRs, specific requirements and their stringency differ across states (Mahdavi \& Westerlund, 2011; NCSL, 2010; Poterba, 1995a). Early studies used one component of the

\footnotetext{
${ }^{23}[\mathrm{~A}]-[\mathrm{F}]$ indicates the five groups of 28 criteria, and the numbers in parentheses means a weighting of each criterion. [A] Restriction on Revenue and expenditure (6), Revenue (5), Expenditure (4), Appropriations (3), Tax revenue (2), General fund expenditure (1); [B] Statutory (0) or constitutional (1); [C] Growth restriction: Less than or equal to inflation and/or population growth (7), Less than or equal to the rate of personal income (6), Limited to growth in the state economy (5), Less than 7\% of state income (4), Greater than $7 \%$ of state income (3), Equal to a share of total revenue or expenditures (2), New or increased taxes and fees (1); [D] Method of approval: Constitutional convention (4), Legislative referendum (3), Citizen initiative (2), Legislative vote (1); [E] Override provisions: No override allowed (4), Voter approval to raise taxes and expenditure of surplus revenues (3), Supermajority vote (2), Declaration of emergency and/or supermajority vote to use emergency funds (1); and [F] Exemptions: Budget reserves (-1), Grants (-1), Capital projects (-1), Debt service (-1), Court mandates (-1), Non-recurring general fund appropriations (-1)
} 
three BBRs or valued each component and aggregated the components. The deficit carryover rule that prohibits governments from transferring budget deficits into the next fiscal year affects state revenues and expenditures (Alt \& Lowry, 1994; Poterba, 1994). ACIR (1987) presented the fiscal stringency index that was measured by four components: the submission of a balanced budget, the passing of a balanced budget by the legislature, three levels of deficit carryover rules, and whether each rule is defined by the constitution or by statutory processes. Hou and Smith (2006) developed the BBR index, claiming that indices in prior studies were measured in ways that "at least partially reflect personal perception, judicial interpretation, and other nonstatutory and nonconstitutional considerations” (p. 27). They suggested nine components of BBRs-categorized by type of rule (technical and political) and phase of the budget cycle. They utilized the index in another study (Hou \& Smith, 2010), and found each BBR's statistically significant effect on fund balances. Mahdavi and Westerlund (2011) tested if BBRs are associated with fiscal sustainability indicators that were measured as fund balances ${ }^{24}$. They adopted the BBR classification of Hou and Smith (2006) and applied four BBRs from the categorization, BBR2, BBR5, BBR7, and BBR9, with the ACIR fiscal stringency indicator's accumulated value. Using bootstrap p-values, they concluded that BBRs are positively related to a fiscal sustainability indicator, general revenues less current expenditures.

In the present study, I adopt the TELs fiscal stringency index from Amiel et al. (2009) and the BBRs rules surveyed by NCSL (2010).

\footnotetext{
24 "B1. Total revenues less total expenditures, B2. General revenues less general expenditures, B3. General revenues less current expenditures, and B4. Own-source general revenues less current general direct expenditures” (Mahdavi \& Westerlund, 2011, p. 959)
} 


\section{External factors for expenditures: Median voters and Business cycle}

The median voter theorem and business cycle model are typical public choice theories that stress economic theoretical methods to explain public policy decision making. First, according to the median voter theorem, median voters are regarded as the decisive group that affects decision making for governmental policy in the majority-voting system of democracy. The median voter is more decisive in determining "the majority-voting equilibrium $^{25}$ ” in an inequality society in which mean income exceeds median income, compared to an equality society which has similar levels of mean and median income such as asymmetric valuation distribution (Hillman, 2009, pp. 415-416). Gramlich and Rubinfeld (1982) found that higher-income individuals did not appear to have greater preference for public spending than lower income individuals, indicating that the median income group more effectively influences public policy than the higher income group. Thus, the median voter theorem implies that median income voters are likely to determine the demand for public goods rather than mean income people (Mueller, 2003, p. 244). Congleton and Bennett (1995) studied whether state highway expenditures were impacted by special interest groups and median voters, finding that the latter-a proxy of median voters' preferences-positively affected expenditures per mile, which they used as a dependent variable indicating state efforts to maintain and improve roads. However, Walden and Eryuruk (2012) yielded different results in an investigation of North Carolina’s state highway investments in 100 counties using the median voter model, the special

\footnotetext{
25 In a democratic political system by popular sovereignty, a majority-voting equilibrium, "there is not majority support in favor of change, particularly in favor of reducing supply” (Hillman, 2009, p. 415).
} 
interest group model, the political model, and the combined model. The study distinguished the investment into construction expenditures and maintenance spending, and adopted lagged value of expenditure to estimate policy lags over time. According to their result, median income change was positively significant only for maintenance spending in the combined model with a two-year lag, and not significant in other models and for construction expenditures.

Second, studies on public economics and public finance have adopted the business cycle as a driver of expenditures. Because government budget is a subset of the whole economy, government expenditure is affected by economic conditions. A proxy for the business cycle can be the unemployment rate (e.g., Hou \& Smith, 2010; McGranahan, 1999) or the deviation values from the mean of gross state product (GSP) growth rate (W. Wang et al., 2007). McGranahan (1999) established five types of classified state expenditures: "current spending, capital spending, intergovernmental expenditures, interest on the debt, and insurance trust expenditures," and tested whether the business cycle, defined as unemployment rate, affects expenditures. The findings indicate that capital is negatively affected by the unemployment rate-additional decrease in the unemployment rate caused capital expenditures to decrease by $\$ 6.93$. Following Hou and Smith (2010) and McGranahan (1999), the present study uses the unemployment rate as the business cycle indicator. 


\subsection{Gaps in literature}

Chapter II reviewed three strands of literature. Admittedly, previous theoretical and empirical studies contributed to expanding current knowledge of government capacity and its influence on the public administration of subnational governments. However, gaps in the research literature remain. The present study indicates several shortcomings in past research, in terms of the (a) theoretical backgrounds used to explain the impact of government capacity on governmental performance and (b) conceptualization and measurement of government capacity.

Previous studies have mentioned government capacity (GC) and suggested that GC is involved in grant allocation and grant (or policy) implementation (Krause, Feiock, \& Hawkins, 2016; Manna \& Ryan, 2011; Nicholson-Crotty \& Nicholson-Crotty, 2015; Terman \& Feiock, 2015). However, these studies did not adduce an organized theoretical framework for the link between GC and performance. For example, Manna and Ryan (2011) did not provide any theoretical background in their explanation of the association between GC and grant competition; they merely cited results from some empirical studies. Moreover, Krause et al. (2016) and Terman and Feiock (2015) utilized GC as an independent variable affecting policy implementation, but did not establish their own theoretical framework accounting for the relation.

Most prior studies conceptualized and operationalized GC using authors’ intuition or citing another research (e.g., Carley et al., 2015; Manna \& Ryan, 2011; Nicholson-Crotty \& Nicholson-Crotty, 2015; Nicholson-Crotty \& Staley, 2012; Terman \& Feiock, 2014). Those researchers simply assigned meaning to the concept of GC based on their practical 
experience and intuition. For instance, Carley et al. (2015) suggested the definition of capacity as "relevant policy experience" and "implementation capacity," and measured it using "the existence and character of renewable portfolio standards (RPS) policy" and "the financial management capacity measure developed by the Government Performance Project (GPP)," respectively. However, they did not provide any theory supporting the measurement. Collins and Gerber (2006), which is cited often in the research literature, adopted the number of government employees per resident as a proxy for GC, but also did not provide a theory to support the operationalization.

Referring to the pros and cons of prior literature, this dissertation proposes theoretical backgrounds, then establishes the theoretical framework, in the next chapter. In the present study, the three stages of ARRA grants (acquisition, implementation, and impact) are regarded as performance of GC. Thus, the theoretical approach of the dissertation begins with general theories pertaining to the achievement of goals, and then proposes more specific frameworks for the link between GC and performance and for the measurement of GC. 


\section{Chapter III. THEORY DEVELOPMENT}

Chapter III describes the theoretical framework for the link between government capacity (GC) and American Recovery and Reinvestment Act of 2009 (ARRA) grants, and describes the concept of GC. The chapter introduces the framework explaining relations between GC and ARRA grant acquisition, implementation, and expenditure recovery. The chapter also reviews theories pertaining to GC and presents the concept and measurement of GC.

\subsection{Theoretical framework}

This section proposes the theoretical framework of the present study. I begin by presenting two background theories: Systems Theory and Resource Based Theory (RBT). Systems theory provides the background logic that is utilized to explain how government capacity (GC) affects ARRA grants. RBT concerns how GC can be measured and why GC is significant for ARRA grants.

\subsubsection{Brief review of Systems theory}

Systems theory is "an approach to organizations that focuses on how they translate inputs into outputs” (Kettl, 2011). Historically, system thinking existed before in the form of a theory to explain organizations. However, subsequent to the research of von Bertalanffy, scholars have utilized General Systems Theory (GST), which can be applied to all general science fields (T.-W. Wang, 2004, p. 394) 
Systems theory is divided into two approaches: closed system and open system. The former views an organization as a machine that is not affected by environment. This approach focuses on "the internal workings of the system" (Kettl, 2011). So, it referred to as mechanistic or nonliving systems approach. The open system approach assumes that an organization is open to the environment. As organic or living systems, organizations react to the impact of the environment and interact with each other.

However, the modern organization theory is more in tune with the open systems theory (Kettl, 2011; Miller, 1965; Sitkin, Sutcliffe, \& Schroeder, 1994; T.-W. Wang, 2004). As an open system organization, a government: receives "inputs of resources" (e.g., equipment and the energies or labor of employees), conducts transformational processes in the throughputs phase, and then produces outputs (public services). Even after outputs, the open-system functions as a feedback loop, which is a learning process for a government (organization) to reflect a positive or negative experience to the new recurring process. (Kettl, 2011). By cycling through the phases of the system, a government becomes a more effective and efficient organization.

For any organization, the most important thing is self-preservation. To do so, systems theory focuses on the purpose of government (organization) and seeks the best way to achieve that purpose-via the process of translating inputs into outputs. Two abilities are critical to an organization's successful processes and viability: (1) “capacity to manipulate or adapt to its external environment” and (2) “capacity to suppress or moderate internal threats” (Kettl, 2011, pp. 102-104). That is, the systems theory implies that as an 
open-system, a government (organization) must continue to enhance its capacity, monitor environmental changes, and adapt to make the best use of the changes.

\subsubsection{Resource Based Theory}

Government capacity (GC) is closely related to resources. Resources significantly affect strategies to build capacity; resources are a characteristic of higher capacity organizations. Public administration researchers have acknowledged the emerging importance of resources by citing Resource Based Theory in recent studies (Bryson, Ackermann, \& Eden, 2007; Lee \& Whitford, 2012).

Resource Based Theory (RBT) or Resource Based View (RBV) emerged when Wernerfelt (1984) proposed the concept, which contends that a firm's performance is dependent on its resources. Before the RBT, the dominant paradigm in industrial organization economics was the structure-conduct-performance (SCP) paradigm, which contends that performance is impacted by a firm's market power in the industry structure (J. B. Barney \& Clark, 2007). According to RBT, organizations that outperform others have

a different portfolio of idiosyncratic resources (J. B. Barney \& Clark, 2007; J. B. Barney, Ketchen, \& Wright, 2011; Lee \& Whitford, 2012). RBT had been previously discussed mainly in the areas of business administration and economics; however, several scholars in public administration have accepted and utilized the theory (Dawes, Cresswell, \& Pardo, 2009; Graddy \& Chen, 2006; Haughton, 1999; Lee \& Whitford, 2012; Pitts, 2005; Yang, Hsieh, \& Li, 2009). In the present study, instead of performing an in-depth investigation 
into the theory itself, I explore characteristics of RBT and apply them to frame the concept of government capacity.

Recognizing that resources are essential to the performance of a firm (or organization), we must first define the concept of resource. J. B. Barney and Clark (2007) proposed four attributes that a firm's resource should have:

(a) it must be valuable, in the sense that it exploits opportunities and/or neutralize threats in a firm's environment, (b) it must be rare among a firm's current and potential competition, (c) it must be imperfectly imitable, and (d) it must be able to be exploited by a firm's organizational process ( $p .57)$.

Resources can be characterized using the VRIO framework, which stands for questions of Value, Rareness, Imitability, and Organization. First, valuable resources are assessed by whether or not a firm overcomes external threats and responds to opportunities by using the resources. By utilizing SWOT (Strengths, Weakness, Opportunities, and Threats) analysis, valuable resources can be examined. Second, resources that are accessible to competitors cannot be exploited to outperform such competitors; when resources are controlled by a small number of firms, these resources can be used for survival and to be competitive. Third, if a resource is difficult to imitate (i.e., imperfectly imitable), a firm has a competitive advantage over others, which requires one or all of historical uniqueness, causal ambiguity, and social complexity. ${ }^{26}$ Lastly, even if the three

\footnotetext{
26 "Firm resources can be imperfectly imitable (or costly to imitate) for one or a combination of three reasons: (a) the ability of a firm to obtain a resource is dependent on unique historical conditions, (b) the link between the resources possessed by a firm and a firm's sustained competitive advantage is
} 
abovementioned conditions are satisfied, a firm should be sufficiently organized to support the resources that have the three attributes (Barney \& Clark, 2007, pp. 57-70).

We will now review examples of resources. The public administration literature (Bryson et al., 2007; Lee \& Whitford, 2012) views the concept of resources as a broad term that refers to the various types of assets that an administration body can exploit to achieve performance and organizational goals. In support of this perspective, J. Barney (1991) stated, "resources include all assets, capabilities, organizational processes, firm attributes, information, knowledge, etc. controlled by a firm that enable the firm to conceive of and implement strategies that improve its efficiency and effectiveness” (p. 101). In addition, intangible and tangible assets are regarded as resources-provided that the assets are utilized “to develop and implement strategies” (Ray, Barney, \& Muhanna, 2004, p. 24). In an empirical study that accounted for RBT, Lee and Whitford (2012) proposed six organizational resources that predicted performance: "administrative (structural) resources, human resources, financial resources, physical resources, political resources, and reputation resources” (p. 690). They operationalized: administrative (structural) resources as the number of members in the top governing structure (Senior Executive Service); human resources as the level of professionalization of its employees; financial resources as spending authority from offsetting collections; and political resources as presidential attention and the agency's public reputation. These factors positively affect organizational performance, which implies that RBT is meaningful in predicting performance.

causally ambiguous, or (c) the resource generating a firm's advantage is socially complex" (Barney \& Clark, 2007). 


\subsubsection{Frame for government capacity and ARRA grant}

Borrowing from Systems Theory and Resource Based Theory (RBT), the present study establishes a theoretical framework that links government capacity and ARRA grants. First, the implication of Systems theory is that output is a result of the process of input and throughput. That is, the performance (output) of government depends on how well the phases of input and throughput performed. In addition, because government is an opensystem organization, the adaptability and manipulability of the external environment are also significant; the input and throughput phases must secure abilities (capacities). Second, RBT implies that good resources are the key factors for a government to outperform other governments. RBT also provides a background to identify the factors that are considered to be components of GC. An empirical study (Lee \& Whitford, 2012) supported the rationale of RBT by considering several resources to be components of capacity (e.g., administrative, human, and financial resources).

Building on Systems Theory and RBT, the present study proposes a framework for the relationship between GC and ARRA grants. Figure 4 presents an open-system, in which output (grant acquisition, grant implementation, and grant impact) depends on input/throughput (state needs, government capacity, state politics, fiscal institution, legislative control, and federal politics). According to the type of output, the set of input and throughput differs. For example, the framework assumes federal politics affect only grant acquisition, whereas state needs affect all outputs. 
Among the factors of input and throughput, government can only control or manage government capacity. Thus, the present study focuses on government capacity as the key independent variable that affects all grant outputs.

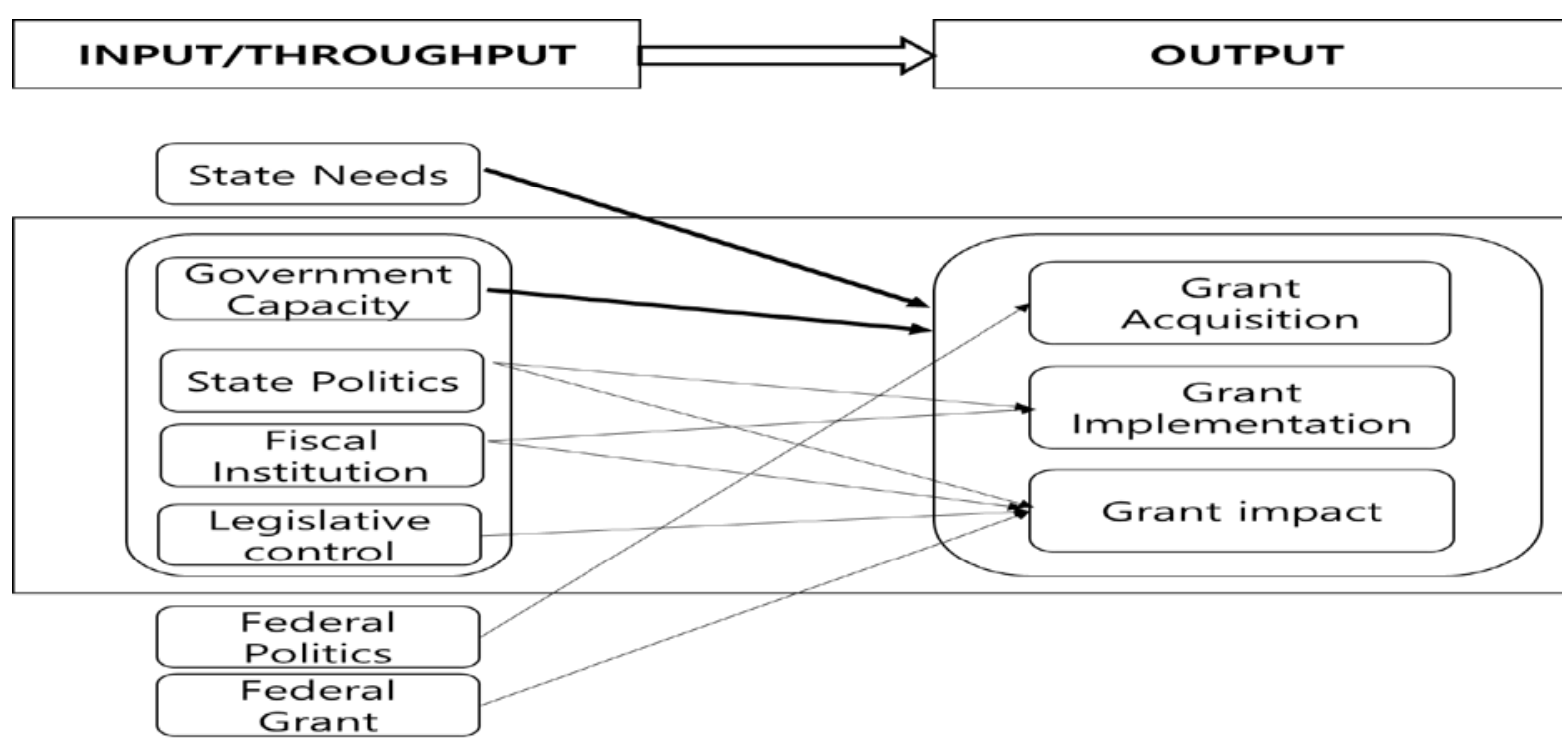

Figure 4 Schematic Model

\subsection{Conceptualization and measurement of Government Capacity}

This section reviews theory development for the concept of government capacity (GC) and suggests a measurement of GC. I present a review of previous literature on this topic, and review the concept of GC and examples of how to measure management capacity and financial capacity. Then, I describe the concept and framework of GC used in the present study and propose an operationalization of GC for the empirical analysis of ARRA grants. 


\subsubsection{Literature review of Government Capacity (Capability)}

Public administration scholars have examined the concept of GC; however, no consensus has been reached on how to define or measure it. The present study explores the concept and the measurement of GC and endeavors to find alternative uses for it. The concept of capacity, in the context of different research studies, is reviewed to compare how the various studies defined and utilized capacity. Then, I introduce empirical studies on GC that investigate management capacity and fiscal capacity.

\section{Concept of government capacity in literature}

The dictionary definition ${ }^{27}$ of capacity is "the ability or power to do, experience, or understand something," "the maximum amount that something can contain," or "amount that something can produce.” A related term, capability, is defined in the dictionary ${ }^{28}$ as “power or ability," "the extent of someone’s or something’s ability,” or “forces or resources giving a country or state the ability to undertake a particular kind of military action.” The common ground between the dictionary definitions of capacity and capability is "ability." While capability focuses on "ability" or "resources," capacity additionally encompasses the meaning of volume to contain something. With respect to "ability," the two concepts have the same dictionary meaning. Academic studies rarely distinguish between the two terms. Most studies in the field of public administration or political science, account for

\footnotetext{
${ }^{27}$ http://www.oxforddictionaries.com/definition/american_english/capacity

${ }^{28}$ http://www.oxforddictionaries.com/definition/american_english/capability
} 
capacity and capability as the power or the ability of government, and regard them as having interchangeable meanings (Bowman \& Kearney, 1988, p. 341).

The first mention and conceptualization of government capacity (GC) occurred in several pioneering studies (e.g., Bowman \& Kearney, 1988; Donahue et al., 2000; Gargan, 1981; Honadle, 1981). Honadle (1981, p.577) defined capacity as "the ability to anticipate and influence change; make informed, intelligent decisions about policy; develop programs to implement policy; attract and absorb resources; manage resources; and evaluate current activities to guide future actions." Ingraham and Donahue (2000, p. 294) stated that management capacity indicates "government's intrinsic ability to marshal, develop, direct, and control its human, physical, and information capital to support the discharge of its policy directions.” Similarly, Donahue et al. (2000, p. 384) described management capacity as a "government's ability to develop, direct, and control its resources to support the discharge of its policy and program responsibilities.” The World Bank (1997, p. 77) refers to state capability as "the ability of the state to undertake collective actions at least cost to society. This notion of capability encompasses the administrative or technical capacity of state officials and of supporting systems and processes, but is much broader than that. It also includes the deeper institutional mechanisms that give politicians and civil servants the flexibility, rules and restraints to enable them to act in the collective interest.” Although Bowman and Kearney (1988, p. 343) did not directly delineate the concept of capacity, their study highlighted the abilities of responsiveness, efficient and effective decision making, and conflict management. They argued that management capacity would be strengthened by developing "program, policy, and resource management skills for utilization in federally funded endeavors” (p. 342). 
Second movers adopted the early studies' conceptualization of capacity and expanded or applied it according to their research focuses. Van Slyke (2003) explained public-management capacity as "personnel, oversight and program audit capabilities, and the necessary communication and political skills” (p. 296). Specifically, for management capacity, personnel must possess "contract-management experience, policy expertise, negotiation, bargaining, and mediation skills” (p. 296). Meanwhile, Hou et al. (2003) classified government capacity as "the administrative capacity approach" and "the governance capability approach.” The former refers to aspects of the administration that considers "the importance of policies, procedures, and resources governing administrative action” (p. 300). The latter approach encompasses external aspects of the administration (e.g., political influences); the authors regarded capability as the rules or equilibrium that are created and restricted by political choice, an institution, and the rule of law—adopting the perspective of New Institutional Economics (NIE). Topinka (2011) explained that the meaning of capacity is simply "power" and that management capacity can be described using the traditional view of administrative management: POSDCoRB (Planning, Organizing, Staffing, Directing, Coordinating, Reporting and Budgeting). He accepted the model of GPP (Government Performance Project) and explained that the model integrates the seven management criteria of POSDCoRB. Selden and Sowa (2004) viewed "management capacity as the degree to which the necessary systems and processes are in place to maintain an organization” (p. 404). Table 3 summarizes GC concepts that prior studies defined. 
Table 3 Concept of Capacity

\begin{tabular}{l|l}
\hline Authors & Concept of Government Capacity \\
\hline Honadle's (1981) & $\begin{array}{l}\text { "the ability to anticipate and influence change; make informed, } \\
\text { intelligent decisions about policy; develop programs to implement } \\
\text { policy; attract and absorb resources; manage resources; and } \\
\text { evaluate current activities to guide future actions." }\end{array}$ \\
\hline $\begin{array}{l}\text { Ingraham and } \\
\text { Donahue (2000) }\end{array}$ & $\begin{array}{l}\text { Management Capacity is "government's intrinsic ability to } \\
\text { marshal, develop, direct, and control its human, physical, and } \\
\text { information capital to support the discharge of its policy } \\
\text { directions." }\end{array}$ \\
\hline World Bank (1997) & $\begin{array}{l}\text { "the ability of the state to undertake collective actions at least cost } \\
\text { to society. }\end{array}$ \\
\hline $\begin{array}{l}\text { Bowman \& Kearney } \\
\text { (1988) }\end{array}$ & $\begin{array}{l}\text { Capability of state government means “(1) to respond effectively } \\
\text { to change; (2) to make decisions efficiently, effectively (i.e., } \\
\text { rationally) and responsively; and (3) to manage conflict.” }\end{array}$ \\
\hline Van Slyke (2003) & $\begin{array}{l}\text { public-management capacity as "personnel, oversight and } \\
\text { program audit capabilities, and the necessary communication and } \\
\text { political skills" }\end{array}$ \\
\hline $\begin{array}{l}\text { Hou, Moynihan, and } \\
\text { Ingraham (2003) }\end{array}$ & $\begin{array}{l}\text { "the importance of policies, procedures, and resources governing } \\
\text { administrative action" }\end{array}$ \\
\hline Topinka (2011) & "power" \\
\hline $\begin{array}{l}\text { Selden and Sowa } \\
\text { (2004) }\end{array}$ & $\begin{array}{l}\text { "the degree to which the necessary systems and processes are in } \\
\text { place to maintain an organization" }\end{array}$ \\
\hline
\end{tabular}

Management Capacity: measurement in empirical studies

Most empirical studies have not developed their own concept of "capacity." The research literature asserts that the concept of government capacity "does not exist on its own” but rather exists “in relation to its application” (Terman \& Feiock, 2014, p. 6). Thus, many studies have presented their measurement methods without a thorough discussion on the definition of government capacity. Carley et al. (2015) explained capacity in terms of relevant technical skills, relevant organizational experiences, adequate resources, cognitive skills, and human capital (p. 116). They measured government capacity with two variables: policy experience and financial management. Policy experience was measured by the 
number of years that a state's renewable portfolio standards was determined for electricity policy; they employed "financial management scores" of the Government Performance Project (GPP) to measure financial management. To measure the concept of administrative capacity, Terman and Feiock (2014) used five components: overall capacity, managerial capacity, dedicated sustainability staffing, lack of staff capacity, and lack of information resources. ${ }^{29}$ Terman and Feiock (2015) (a) measured "administrative capacity” using the number of financial management employees; (b) "policy capacity" was quantified as a dummy variable in which a city was coded as " 1 " if the city had at least one member for sustainability programs; and (c) “management structure” was coded as " 1 ” if a municipality was managed using a council-manager system (p. 333). To measure capacity, Manna and Ryan (2011) used the acquisition of a planning grant from the Bill and Melinda Gates Foundation; the study also logged population density. The authors assumed that the grantaward indicates that a state has greater ability to implement policies, because the state's capacity was boosted by the grant, compared to a state that failed to obtain the grant. In addition, population density was utilized due to the assumption that an urban state has greater ability to apply for and implement programs—compared to a rural state. Table 4

\footnotetext{
${ }^{29}$ (1) The overall capacity was measured with "Number of financial management staff members in a municipal government per 1000 residents," and (2) the managerial capacity's proxy was "Council manager form of government with appointed city manager." The other three components were measured by the survey. (3) The dedicated sustainability staffing was measured by "Which scenario best describes staffing sustainability activities in your city? (Check the response that best applies; choices include no dedicated staffing for sustainability, dedicated staff based in city manager/CEO office or equivalent, dedicated staff based in the mayor or city council office, and dedicated staff based in one or more departments)." (4) The lack of staff capacity was asked as "[In relation to EECBG projects] on a scale from $1=$ "not an obstacle" to 5 = "substantial obstacle"; please rate how [lack of staff capacity] influences your city's ability to reduce its overall energy consumption.” (5) The lack of information resources was measured by "[In relation to EECBG projects] on a scale from $1=$ "not an obstacle" to 5 = "substantial obstacle"; please rate how [lack of informational resources] influences your city's ability to reduce its overall energy consumption.” (pp. 12-13)
} 
summarizes components of management capacity and measurements that previous literature discussed.

Table 4 Definitions and Measurements of Government Capacity

\begin{tabular}{|c|c|c|}
\hline Studies & Components of capacity & Measurement \\
\hline $\begin{array}{l}\text { Carley et al. } \\
\text { (2015) }\end{array}$ & $\begin{array}{l}\text { Relevant technical skills, } \\
\text { relevant organizational } \\
\text { experiences, adequate } \\
\text { resources, cognitive skills, } \\
\text { and human capital }\end{array}$ & $\begin{array}{l}\text { Government relevant experience (the } \\
\text { number of years of a state's } \\
\text { renewable portfolio standards (RPS) } \\
\text { for the electricity policy), } \\
\text { financial management capacity } \\
\text { (financial management scores of } \\
\text { GPP) }\end{array}$ \\
\hline $\begin{array}{l}\text { Bowman and } \\
\text { Kearney (1988) }\end{array}$ & $\begin{array}{l}\text { Responsiveness, efficient } \\
\text { and effective decision } \\
\text { making, and conflict } \\
\text { management }\end{array}$ & Factor analysis from 32 variables \\
\hline $\begin{array}{l}\text { Collins and } \\
\text { Gerber (2008) }\end{array}$ & $\begin{array}{l}\text { Ability to compete for and to } \\
\text { manage grant contracts }\end{array}$ & $\begin{array}{l}\text { The number } \\
\text { of financial administrators and other } \\
\text { government administrators for every } \\
1,000 \text { county residents }\end{array}$ \\
\hline $\begin{array}{l}\text { Jennings, Hall, } \\
\text { and Zhang } \\
\text { (2012) }\end{array}$ & $\begin{array}{l}\text { Human, physical, and } \\
\text { information capital to } \\
\text { support the discharge of its } \\
\text { policy directions (accepting } \\
\text { the definition of Ingraham } \\
\text { and Donahue) }\end{array}$ & $\begin{array}{l}\text { GPP scores of four dimensions } \\
\text { (human resources, financial } \\
\text { management, infrastructure, } \\
\text { information) }\end{array}$ \\
\hline $\begin{array}{l}\text { Terman and } \\
\text { Feiock (2015) }\end{array}$ & $\begin{array}{l}\text { (1) Administrative capacity, } \\
\text { (2) Policy capacity, } \\
\text { (3) Management structure }\end{array}$ & $\begin{array}{l}\text { (1) The number of financial } \\
\text { management employees, } \\
\text { (2) dummy, if the city had a member } \\
\text { for sustainability programs ( } 1 / 0) \text {, } \\
\text { (3) Council-manager form }\end{array}$ \\
\hline $\begin{array}{l}\text { Terman and } \\
\text { Feiock (2014) }\end{array}$ & $\begin{array}{l}\text { (1) Overall capacity, } \\
\text { (2) Managerial capacity, } \\
\text { (3) Dedicated sustainability } \\
\text { staffing, } \\
\text { (4) lack of staff capacity, } \\
\text { (5) lack information } \\
\text { resource }\end{array}$ & $\begin{array}{l}\text { (1) Number of financial management } \\
\text { staff members per } 1000 \text { residents, } \\
\text { (2) Council-manager form, } \\
(3 \sim 5) \text { from survey questions }\end{array}$ \\
\hline $\begin{array}{l}\text { Manna and Ryan } \\
\text { (2011) }\end{array}$ & $\begin{array}{l}\text { Administrative talents and } \\
\text { resources }\end{array}$ & $\begin{array}{l}\text { The acquirement of a Gate grant and } \\
\text { the logged population density }\end{array}$ \\
\hline
\end{tabular}




\section{Fiscal Capacity: concept and measurement}

While government capacity mainly concerns management capacity, a subordinate concept to GC concerns fiscal policy. It is called fiscal capacity, but is also referred to as “tax capacity" because major revenues come from taxes. Most studies have discussed fiscal capacity mainly in terms of ability to raise revenue (Akin, 1973; Compson, 2003; Dincecco \& Prado, 2012; Fox, 1977; Kincaid, 1989; Ladd, 1975; Lucke, 1984). The Advisory Commission on Intergovernmental Relations (ACIR, 1962, p. 3) defined fiscal capacity as "the resources which a taxing jurisdiction can tax to raise revenue for public purposes.” Because the aspect focuses on how much governments can secure revenue through taxes, some scholars prefer the term tax capacity over fiscal capacity (W. D. Berry \& Fording, 1997; Lucke, 1984; Tannenwald \& Cowan, 1997). Tax capacity is defined by ACIR as "the capability of a governmental entity to finance its public services" (W. D. Berry \& Fording, 1997, p. 158). Table 5 summarizes prior studies regarding the concept of fiscal capacity.

Table 5 Concept of fiscal capacity

\begin{tabular}{l|l}
\hline Authors & Concept of Fiscal Capacity \\
\hline Fox (1977) & "the ability of governments to obtain resources for public purposes" \\
\hline Lucke (1984) & "the ability of a government to raise revenue" \\
\hline Compson (2003) & "a state's ability to raise revenues from its own sources" \\
\hline $\begin{array}{l}\text { Dincecco \& Prado } \\
(2012)\end{array}$ & "the ability of states to raise tax revenues" \\
\hline Kincaid (1989) & "the ability to raise own source revenues to meet expenditure choices" \\
\hline $\begin{array}{l}\text { Berry \& Fording } \\
(1997)\end{array}$ & state tax capacity is "the amount of revenue the state would collect" \\
\hline ACIR (1962) & $\begin{array}{l}\text { "Fiscal capacity is a quantitative measure intended to reflect the } \\
\text { resources which a taxing jurisdiction can tax to raise revenue for } \\
\text { public purposes." }\end{array}$ \\
\hline
\end{tabular}


Three types of measurement methods for fiscal capacity are used by scholars who regard the concept as tax capacity. Per capita state personal income—-measured by dividing personal income by the number of residents—-was the first method used to measure fiscal capacity (Akin, 1973; Compson, 2003; Fox, 1977; Ladd, 1975; Lucke, 1984). However, this approach has an inherent weakness because it cannot account for all of a state's resources. Moreover, some states do not directly collect income tax, and even though states rely "primarily on the individual income tax for revenue, states make only limited use of that tax" (Lucke, 1984, p. 333).

The second method used to measure fiscal capacity concerns the representative tax system (RTS) ${ }^{30}$. In fact, RTS does not directly measure fiscal capacity but does compare states by creating a fiscal capacity index. The term "representative" indicates average or typical. Construction of the index comprises three steps (Kincaid, 1989, p. 11). First, tax capacity is calculated by "adding up the hypothetical yields" from all tax-bases, the 26 bases across eight categories: (1) total property, (2) general sales and gross receipts, (3) personal income, (4) corporation income, (5) selective sales, (6) licenses, (7) severance, and (8) estate and gift taxes (pp.10-11). Second, tax capacity is divided by the population of each state. Third, the index, for comparative purposes, is calculated by dividing the per capita tax capacity by the U.S. average per capita tax capacity. Converting it into a percentage, the value of the index is distributed up to one hundred (p.11). The attribute of the measurement using "average" enables comparison of a specific policy or a tax across

\footnotetext{
30 Similarly, the representative revenue system (RRS) concludes other revenue sources, such as user fees, as well as taxes (Kincaid, 1989; Tannenwald \& Cowan, 1997).
} 
states. However, this characteristic creates a weakness in the index: the method cannot be used to compare states across time.

The third method used to measure fiscal capacity concerns total taxable resources (TTR). The TTR approach was modified at the suggestion of Compson (2003) and is currently used by the U.S. Department of Treasury, which reports TTR yearly. According to Mikesell (2007), TTR is calculated by (1) gross state product (GSP) (2) less non-taxable resources, and (3) income resources that are not counted in GSP. ${ }^{31}$ The non-taxable resources include "federal indirect business taxes, social insurance contributions, and federal civilian enterprise surpluses” (p. 537). The income resources encompass “dividends and interest earned from out-of-state, certain transfers from the federal government, net realized capital gains, and earnings of residents who live out of state” (p. 537). Compared to RTS, TTR has pros and cons as a measurement of fiscal capacity. With TTR, we can compare states over long-term periods; it is possible to compare each state's patterns over time and all states across time. However, TTR is less useful than RTS in the comparison of a specific tax or a policy in terms of tax capacity (p.537).

Related to tax capacity, the term tax effort is defined as "the extent to which it utilizes its tax capacity” by ACIR (W. D. Berry \& Fording, 1997, p. 158), which refers to “how heavily a state utilizes its tax bases" (Kincaid, 1989, p. 11). Tax effort is measured

\footnotetext{
31 TTR equals "the unduplicated sum of the income flows produced within a state and income flows received by its residents which a state can potentially tax.” (Compson 2003, p.59)
} 
by the ratio of tax collections to tax capacity ${ }^{32}$ (W. D. Berry \& Fording, 1997, p. 160; Kincaid, 1989). Thus, states can have higher fiscal capacity with lower tax effort, or lower fiscal capacity with higher tax effort. For instance, Kincaid (1989) and Mikesell (2007) presented an examination in which the relation between state fiscal capacity and state tax effort has negative correlations.

The other approach to fiscal capacity focuses on the portion of government revenue dedicated to spending. When evaluating the fiscal policy of a government, it is critical to consider how to secure revenue and how to utilize the revenue. Following that rationale, higher fiscal capacity would indicate a government's potential ability to procure revenue, and higher fiscal capacity helps governments develop public services. Mikesell (2007, p. 545) asserted that "states with higher fiscal capacity have greater budgetary possibilities than do those with lower capacity.”

Hou and Moynihan (2008) used the concept of countercyclical fiscal capacity (CCFC) and asserted that fiscal capacity "also includes the ability to allocate financial resources to deal with future events (p.141)." CCFC is regarded as "the fiscal [tool] to minimize disruption from revenue shocks (p.142).” The authors explained that the countercyclical fiscal capacity "depends a great deal on predictable rules that direct and frequently constrain the behavior of public officials” (p.141). They measured CCFC by using the following rules: budget stabilization fund (BSF) and the general fund balance (GFB). According to the authors, fiscal capacity is very important to a government facing

\footnotetext{
32 "ACIR then defines a state's tax capacity as the amount of revenue the state would collect if it applied this set of national-average tax rates to each of its own tax bases (W. D. Berry \& Fording, 1997, p. 160).”
} 
challenges such as economic downturn and revenue shock, because the capacity can help a government mitigate the shock and cope with the economic emergency. The authors insisted that governments with CCFC (BSF and GFB) would "be better able to have highperforming public services and prosperous economies even as they deal with recessions than governments where such tools are absent” (p.142).

Borge (2008) explained the relationship between fiscal capacity and government efficiency, asserting that fiscal capacity could lower efficiency. In support of their position, they argued that governments with higher fiscal capacity are likely to have "good service standards even if they are not fully efficient (p.483).” If so, there may be neither a strict check from politicians nor political controversy. Moreover, they argued that higher fiscal capacity entails "larger operating surpluses and less fiscal stress," which does not require a hard restriction on budgeting (p. 483). Borge used government revenue as a proxy of fiscal capacity. ${ }^{33}$

Y. Wang and Zhao (2014) used the concept of fiscal capacity to explain government behavior to Public-Private Partnership (PPP). The authors asserted that preference of PPP depends on the financial pressure of a government. So, higher fiscal capacity was anticipated to have a negative sign to the PPP preference. Per capita annual state revenue was used to account for fiscal capacity.

\footnotetext{
33 "Since the local taxes are of the revenue-sharing type, the revenue measure can be interpreted as an indicator of fiscal capacity. Differences in fiscal capacity reflect differences in tax bases and the design of the grant system.” (Borge, 2008, p. 479)
} 
Zhao and Guo (2010) utilized fiscal capacity to explain higher bond ratings. They followed a rationale in which a government with higher fiscal capacity would be "more capable of making debt payments on time (p.567)" and have positive impacts on their bond rating. However, in their empirical examination, fiscal capacity measured by per capita general fund revenue had negative effects on GO bond rating, and the authors presented an alternative interpretation of the result—stating per capita general fund revenues "reflect not only fiscal capacity but also fiscal burden (p. 574)”.

In sum, the research literature on fiscal capacity was reviewed using two aspects: securing and utilizing revenue. Because aspects both concern revenue, any method used to measure fiscal capacity should choose a proxy that reflects revenue. Another implication from the review is that the measurement of fiscal capacity can vary according to the topic of research or the purpose. Mikesell (2007) stated, "no single approach to capacity measurement will meet all analytical expectations.” Thus, provided that the measurement retains inherent attributes of fiscal capacity, the method of measurement can be flexible.

\subsubsection{Concept and framework for government capacity}

Following the previous review of theories on government capacity and Resource Based Theory (RBT), I now present two arguments. First, as Honadle (1981) mentioned, "it is unlikely that a consensus definition of 'capacity' will ever be reached" (p. 575); it is difficult to narrowly define the concept of capacity into a single aspect. Instead, it is appropriate to define the concept in relation to its application in a research case. Based on the literature review of government capacity, three implications were found: (1) capacity 
means ability; (2) capacity is related to resources; and (3) capacity reflects systems. Thus, the present study comprehensively defines capacity as: the ability of government to make its performance by utilizing resources and by managing systems.

Second, to measure the defined concept of GC, specified components of GC are required. The present study refers to RBT for the appropriate components. RBT implies that resources are the key success factors for a government (organization) to achieve goals. Which resource is appropriate depends on the process of government policy and the nature of the resource. Systems theory divides the policy process into four phases: input, throughput, output/outcome, and feedback. Because governments can control resources only in the input-throughput phases, resources in these phases have greater importance. Moreover, resources can be classified as tangible (e.g., human resources) and intangible assets (e.g., reputation and knowledge/skills). Donahue et al. (2000) stated, “capacities are key components of the black box of public administration; they comprise a set of intervening variables in the equation that relates public production inputs and policy and program performance” (p. 382). The present study also assumes that output and outcome is determined by a combination of capacities. Tangible resources are given or supplemented physically, but intangible capacity is learned in the feedback process from success or failure in output and outcome.

Figure 5 depicts the framework for the concept of government capacity_based on systems theory and resource-based theory. First, in the policy process, governments can control their own resources only in the input and throughput phases. So, government capacity should be defined and measured by the resources in the phases. Prior studies 
(Bowman \& Kearney, 1988; Honadle, 1981) support the approach, which argues that capacity building is considered with “a series of inputs.” Admittedly, resources or inputs do not necessarily assure great performance; however, they, as indicators of capacity, are good tools for anticipating output and outcome and for comparing states (Bowman 1988, p. 343). Second, even in the input/throughput phases, resources are categorized into tangible and intangible. In reality, both tangible and intangible resources work together "to enable the execution of a particular business [administrative] process” (Ray et al., 2004, p. 26).

Policy process (systems theory)

\begin{tabular}{l|l|l|l|}
\cline { 3 - 4 } \multicolumn{1}{c|}{} & Input/Throughput & Output/Outcome \\
\cline { 2 - 3 } $\begin{array}{l}\text { Resources } \\
\text { (Resource } \\
\text { based } \\
\text { theory) }\end{array}$ & Tangible & $\begin{array}{l}\text { Human resource capacity, } \\
\text { Financial resource capacity }\end{array}$ & Grant Acquisition, \\
\cline { 2 - 3 } & Intangible & $\begin{array}{l}\text { General management capacity, } \\
\text { Previous Experience capacity }\end{array}$ & Grant Implementation, \\
Grant impact
\end{tabular}

Figure 5. Framework for government capacity

Following the framework of capacity, the present study proposes two groups (tangible and intangible) and four components (human resource, financial resource, general management, and previous experience) of government capacity. The first tangible resource capacity is the ability of human resource (capital), which is fundamental to the management and operation of the government. The second tangible resource capacity, financial resource capacity, indicates revenue as the ability (fiscal policy) of governments to disburse. Intangible resource capacities reflect governments’ ability to perform a policy, 
which encompass general management capacity and previous experience capacity. The two tangible resources are related to the input phase, and intangible resources indicates the throughput phase.

\subsubsection{Measurement of government capacity in the study}

In addition to the framework for the concept of government capacity, it is also important to set specific measurements of the components of GC. This section proposes specific proxies of each component of GC_-including references to prior literature.

In this regard, empirical studies pertaining to government capacity (GC) have two implications. First, most empirical studies are not determined to specify a precise definition of government capacity; these studies flexibly apply GC to different measurements. Second, the meaning of GC can vary according to each situation and policy area. Thus, the present study focuses on finding appropriate components of government capacity regarding the measurement of GC of state departments of transportation (DOTs).

Most studies on government capacity present human resource (HR) capacity as a key component of GC. One aspect of HR capacity is the size of the human resource. The present study measures it by the number of DOT employees per 1000 residents, following the research literature (Collins \& Gerber, 2008; Terman \& Feiock, 2015).

As an additional aspect of HR capacity, I propose the quality of human resources. Admittedly, it is difficult to measure quality of human resource using a quantitative proxy; a qualitative study might be more appropriate for this task. However, as the best alternative 
method to capture the degree of the quality for a quantitative analysis, the present study utilizes the level of payroll compared to the level of median income in a state. According to the efficiency wage theory ${ }^{34}$, a higher wage than the opportunity cost of labor induces workers to be devoted to their organization and increase productivity or quality. A similar rationale is presented by the job-satisfaction theory. Wage is an important factor for job satisfaction, and higher salary and satisfaction with salary increase organizational performance (Selden \& Sowa, 2004). Thus, the relative level of payroll can be considered a reasonable variable to use as a proxy of quality of human resource.

The present study proposes financial resource capacity as the other tangible government capacity. As a barometer of government capacity to perform fiscal policy, revenue is the most important. Several studies (e.g., Borge, 2008; Y. Wang \& Zhao, 2014; Zhao \& Guo, 2010) also used government revenue to measure fiscal capacity. Instead of the "fiscal capacity" terminology, I employ "financial resource capacity.” The term fiscal capacity may confuse readers who are familiar with tax capacity—because fiscal capacity represents tax capacity (the size of taxable resources) as well as revenue. So, financial resource capacity indicates resources that are used for transportation, which refers to "taxes and charges levied on transportation-related activities and used specifically for transportation purposes" (Bureau of Transportation Statistics, 2014). Thus, financial resource capacity is measured by summation of motor fuel taxes, motor vehicle taxes, and charges, which is standardized by the number of residents.

\footnotetext{
34 "The fundamental feature of these models is the claim that employers elicit productivity or quality enhancing behaviors from employees by paying wages above the opportunity cost of labor (Rebitzer, 1995, p. 107).”
} 
Lastly, the study proposes two intangible resource capacities, which is related to the ability of government to perform a policy. As a similar term, there is the concept of policy capacity. I introduce several definitions of policy capacity. Painter and Pierre (2004) defined policy capacity as the ability "to marshal the necessary resources to make intelligent collective choices about and set strategic directions for the allocation of scarce resources to public ends” (p.2). Polidano (2000) also defined policy capacity as "the ability to take decisions on the basis of a knowledgeable assessment of a comprehensive range of information, and through a process which brings together the various agencies of government that are involved in the area” (p.809). Howlett (2009) explained, following Fellegi (1996), policy capacity “as a loose concept which covers the whole gamut of issues associated with the government's arrangements to review, formulate and implement policies within its jurisdiction” (pp. 161-162). These definitions share common ground. First, policy capacity requires a comprehensive ability to cover the overall process ("whole gamut"). Second, policy capacity has the feature of intangible ability ("intelligent collective choices" and "knowledgeable assessment”). Comprehensive intangible ability accumulates from repeated learning and experience from the policy process. From the concept of policy capacity, the present study proposes two intangible resource capacities: general management capacity and previous experience. As comprehensive abilities of government to perform transportation policy, they are learned by the repeated experience. In terms of ARRA transportation grants, thus, intangible resource capacities are measured by infrastructure management scores (measured by GPP) and the amount of previously funded federal grants. In Table 6, I summarize GC components and measurement. 
Table 6 Components and measurement of GC

\begin{tabular}{|c|c|}
\hline Variable & Measurement \\
\hline $\begin{array}{l}\text { Human resource capacity1: } \\
\text { size of human resource }\end{array}$ & Number of DOT employees per 1000 residents \\
\hline $\begin{array}{l}\text { Human resource capacity2: } \\
\text { quality of human resource }\end{array}$ & $\begin{array}{l}\text { Total amount of DOT Payrolls / number of DOT employees } \\
\text { / state median income x } 100\end{array}$ \\
\hline Financial resource capacity & $\begin{array}{l}\text { Transportation revenue (motor fuel taxes, motor vehicle } \\
\text { taxes, and charges)/ residents }\end{array}$ \\
\hline $\begin{array}{l}\text { General management } \\
\text { capacity } \\
\text { Previous experience }\end{array}$ & $\begin{array}{l}\text { GPP (government performance project) infrastructure } \\
\text { scores } \\
\text { Amount of federal grants }\end{array}$ \\
\hline
\end{tabular}

As presented above, the dissertation uses secondary data for measuring GC. The measurement with secondary data is not enough to reflect the component of GC. If primary data were supplemented, the operationalization would be more persuasive. I tried to make good deficiencies for measuring GC, especially HR quality and intangible resources, by using survey methods. However, due to the low level of response rate (30\%), the survey data were not utilized in the dissertation. I disclose the survey questionnaires and responses in appendices. 


\section{Chapter IV. RESEARCH QUESTION, METHOD, AND DATA}

Chapter IV presents research questions, analysis method, and data for analysis—divided into three sections, according to the three stages of an ARRA transportation grant: acquisition, implementation, and impact. Each section explains the rationales of the three research questions and their hypotheses, model specifications, and data with descriptions of the variables.

\subsection{Grant acquisition: Research Question, Method, and Data}

\subsubsection{Research question}

The first research question is "Why do some states receive more ARRA grants than others and to what extent does this depend on government capacity?” There are two main types of grants, formula-based grants and competitive (discretionary) grants. As indicated by their name, formula grants are allocated by a formula with pre-determined multiple criteria (e.g., population). Unlike formula grants, competitive grants are not guaranteed and depend on many factors, including the applicant's ability to outperform the other candidates. Each federal grantor establishes its own merit-based criteria for selecting appropriate recipients, and subnational applicants do their best to develop and submit competitive proposals. However, outcomes of the competitions vary across applicants, and the reason for the outcomes are less understood. Focusing on competitive grant distribution, the present study examines the distribution of competitive grants in the grant-in-aid cycle during the Great Recession in an attempt to provide a better understanding of what makes 
some states more competitive than others, using the key independent variable: government capacity. Thus, my research hypothesis is: Governments with higher capacity will receive a greater amount of ARRA competitive grants.

\subsubsection{Modeling grant acquisition}

To test the effects of government capacity on ARRA grant acquisition, I developed the analysis model, which explains the dependent variable as a function of government capacity, federal politics, and state needs.

Amount of competitive grants per capita $=\mathrm{f}$ (government capacity, federal politics, state needs)

The function is expressed in the mathematical form,

$$
\text { Grant }=\mathrm{e}^{\alpha+\beta_{i} \mathrm{GC}+\gamma_{i} \mathrm{FP}+\delta_{i} \mathrm{SN}+\varepsilon}
$$

It is transformed by taking the natural log on the both sides of the function, that is,

$$
\ln (\text { Grant })=\alpha+\beta_{i} \mathrm{GC}+\gamma_{i} \mathrm{FP}+\delta_{i} \mathrm{SN}+\varepsilon
$$

where GC is government capacity, FP indicates federal politics, and SN means state needs. The form of the function is called a log-linear model, because only the dependent variable is expressed in logarithms, whereas regressors are expressed in levels. A log-linear model can be used when a dependent variable has all positive values and when residuals of an original regression model have a positive skewness. As Figure 6 below shows, if the dependent variable (i.e., Grant) is used without taking the natural log, the residuals of the 
linear-linear model have a positive skewness distribution. However, in the log-linear model for predicting effects of explanatory variables on Grant, the distribution of residuals appears as a normal distribution.
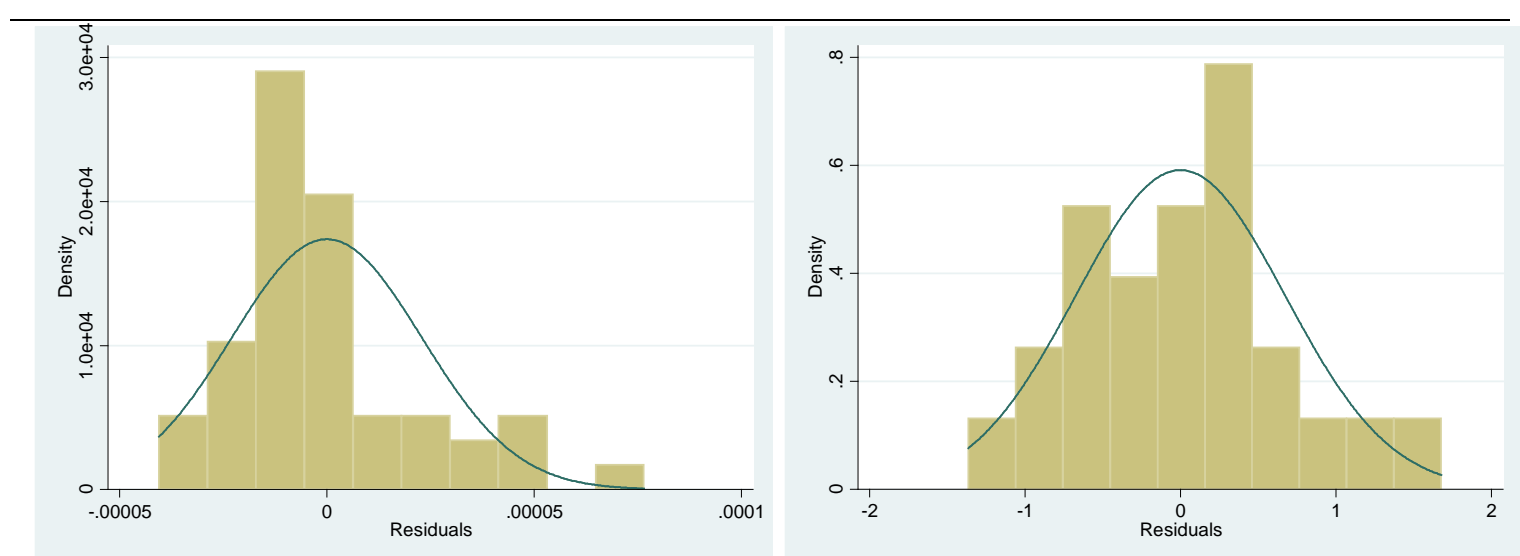

(a) Positive skewness in Origial model

(b) Normal distribution in Log-linear Model

Figure 6. Distributions of residuals

\subsubsection{Data and variables}

In order to examine whether and how the attainment of federal funds depends on state government capacity (GC), the study constructs measurements of government capacity (GC) and tests its effect on the amount of federal competitive grants acquired by a state. The analysis covers all 50 U.S. states during the Great Recession (December 2007- June 2009).

As seen in Table 7, the dependent variable, ARRA grant, is set as a state government's amount of competitive grant awards, which is operationalized by a state's 
sum of competitive grants awarded by the federal department of transportation. The data source is Recovery.gov.

Table 7 Dependent variable of research question 1

\begin{tabular}{ll}
\hline Variables & Measurement \\
\hline Log (amount of competitive grants) & Log (sum of DOT competitive grants under ARRA) \\
\hline
\end{tabular}

In terms of the relationship between government capacity and federal grants, the research literature stresses that government capacity plays an important role in grant competition (Collins \& Gerber, 2008; Manna \& Ryan, 2011). Government capacity is an indicator of government ability to thoroughly prepare grant competition in the aspect of grantees. Furthermore, GC is a good indicator for grantors to screen out low quality governments that may fail to successfully implement the grant program. Thus, the present study uses government capacity as an independent variable. As demonstrated in the prior chapter and Table 8, GC is categorized into three variable groups: human resource capacity, financial resource capacity, and intangible resource capacity. Human resource capacity is measured by the size of human resource (the number of government employees) and the quality of human resource (payrolls per employee); (2) financial resource capacity is demonstrated by transportation revenue; and (3) intangible resource capacity is measured by GPP infrastructure scores and the received amount of discretionary grants in 2008. 
Table 8 Government capacity measurement

\begin{tabular}{l|l}
\hline Variable & Measurement \\
\hline $\begin{array}{l}\text { Human resource capacity 1: size of } \\
\text { human resource }\end{array}$ & Number of DOT employees per 1000 residents \\
$\begin{array}{l}\text { Human resource capacity 2: quality } \\
\text { of human resource }\end{array}$ & $\begin{array}{l}\text { Total amount of DOT Payrolls / number of DOT } \\
\text { employees / state median income x 100 }\end{array}$ \\
\hline Financial resource capacity & $\begin{array}{l}\text { Transportation revenue (motor fuel taxes, motor } \\
\text { vehicle taxes, and charges)/ residents }\end{array}$ \\
\hline General management capacity & $\begin{array}{l}\text { GPP (government performance project) } \\
\text { infrastructure scores } \\
\text { Amount of federal grants }\end{array}$ \\
\hline
\end{tabular}

Although grant competition is initially reviewed by the federal government, the final decision or authorization is made by Congress. Thus, federal politics are an important factor to explain federal fund allocation-in terms of competition between congressmen to secure funds for their home states, according to the pork barrel hypothesis. Referring to the research literature (e.g., Evans, 1994; Lazarus \& Steigerwalt, 2009; Young \& Sobel, 2013), as described in Table 9, the present study inputs two indicators of the power of congressional representatives from each state: the number of appropriations committee members and the number of transportation committee members.

Table 9 Federal politics measurement

\begin{tabular}{l|l}
\hline Variable & Measurement \\
\hline Power of congressional representatives from each state 1 & $\begin{array}{l}\text { Number of Appropriations } \\
\text { committee members } \\
\text { Number of Transportation } \\
\text { committee members }\end{array}$ \\
\hline
\end{tabular}

One function of a grant is to redistribute wealth (or resources) for equality across states. The Recovery Act was also enacted to help economies recover and to support 
economically disadvantaged regions (Gimpel et al., 2012; Young \& Sobel, 2013). Thus, following previous research, the present study assumes grants are associated with state needs, resulting in three variables: urbanization (population density), economic condition (unemployment rate), and median voters (median income), as seen in Table 10.

Table 10 State needs measurement

\begin{tabular}{l|l}
\hline Variable & Measurement \\
\hline Urbanization & Population density/100 \\
Economic condition & Unemployment rate \\
Median voters & Median income/1000 \\
\hline
\end{tabular}

Data come from multiple sources, including Recovery.gov, USAspending.gov, the Book of States, U.S. Census, etc. Detailed information of each variable is described in the Table 11 below. All explanatory variables reflect values in 2008.

Table 11 Data source

\begin{tabular}{|c|c|c|}
\hline \multicolumn{2}{|l|}{ Variable } & Source \\
\hline $\begin{array}{l}\text { ARRA } \\
\text { grants }\end{array}$ & Log (amount of competitive grants) & Recovery.gov \\
\hline $\begin{array}{l}\text { Government } \\
\text { Capacity } \\
\text { (GC) }\end{array}$ & $\begin{array}{l}\text { Human resource capacity 1: size of human } \\
\text { resource } \\
\text { Human resource capacity 2: quality of human } \\
\text { resource } \\
\text { Financial resource capacity: transportation } \\
\text { revenue } \\
\text { General management capacity: policy } \\
\text { experience for infrastructure management } \\
\text { Previous experience: policy experience for grant }\end{array}$ & $\begin{array}{l}\text { Annual Survey of } \\
\text { Public Employment \& } \\
\text { Payroll } \\
\text { Book of States and } \\
\text { Census Bureau } \\
\text { GPP report } 2008 \\
\text { USAspending.gov }\end{array}$ \\
\hline $\begin{array}{l}\text { Federal } \\
\text { Politics }\end{array}$ & $\begin{array}{l}\text { Power of Congressmen from each state } 1 \\
\text { Power of Congressmen from each state } 2\end{array}$ & $\begin{array}{l}\text { Congressional } \\
\text { directory }\end{array}$ \\
\hline State Needs & $\begin{array}{l}\text { Urbanization } \\
\text { Economic condition } \\
\text { Median voters }\end{array}$ & $\begin{array}{l}\text { Census Bureau } \\
\text { Bureau of Labor } \\
\text { Statistics } \\
\text { Census Bureau }\end{array}$ \\
\hline
\end{tabular}




\subsection{Grant implementation: Research Question, Method, and Data}

\subsubsection{Research question}

The second research question is "Does government capacity affect the implementation of ARRA grants? If so, to what extent?" The primary goal of an ARRA grant is to spend funds as soon as possible to stimulate the economy. Though the Great Recession ended in FY 2009, state governments had to continue reporting their progress in fund implementation activities. According to "the DOT weekly financial and activity report," twenty-nine states did not complete spending the ARRA grants, and nineteen states implemented the ARRA grants spending less than $90 \%$ of their obligations. So, the rate at which recipient governments spent or implemented ARRA grant varied across states.

The present study investigates whether the difference in the implementation (spending) rate depended on state government capacity. More specifically, I tested whether and how much pacing in ARRA grant implementation was affected by government capacity. Thus, the research hypothesis for the second research question is Governments with higher capacity would implement a greater proportion of obligated ARRA grants than others.

\subsubsection{Modeling grant implementation}

To test the hypothesis, the analytical model explains variation in the implementation rate of GC and other control variables. Specifically, the study models implementation pace_-as affected by government capacity, state politics, state needs, and fiscal institution. The basic specification is expressed as: 
Implementation pace

$=\mathrm{f}$ (government capacity, state politics, state needs, fiscal institution)

The equation is composed under the assumption of linear combination, and the function is expressed in the mathematical form,

Grant implementation rate rit $=\alpha+\beta_{\mathrm{i}} G C_{i t-1}+\gamma_{\mathrm{i}} S P_{i t-1}+\delta_{\mathrm{i}} S N_{i t-1}+\theta F I_{i t-1}+\varepsilon$,

where GC represents government capacity, SP indicates state politics, SN means state needs, FI represents fiscal institutions.

\subsubsection{Data and variables}

The unit of analysis is the Department of Transportation in the 50 U.S. states. ${ }^{35}$ The time range of data is 2009 to 2012. ARRA funds were initially designed to be completely spent no later than 2011 (Carley et al., 2015, p. 114); however, as described above, many states failed to do so by 2011 and were allowed to use the funds until 2013. So, the present study tests the model using available data of 2009-2012.

The dependent variable is implementation pace, measured by the percentage of a state's outlays in the amount of obligated funds. I set the implementation pace separately in formula grants, competitive grants, and total grants (combining the two grants). Data were obtained from DOT weekly financial and activity reports in Recovery.gov. Table 12 presents the detailed information of variables.

${ }^{35}$ In the real analysis, Nebraska was omitted because it does not have partisanship in the legislature. 
Table 12 Dependent variable of research question 2

\begin{tabular}{l|l}
\hline Variables & Measurement \\
\hline Implementation pace of formula grants & (formula grants outlays / obligations)x100 \\
\hline $\begin{array}{l}\text { Implementation pace of competitive } \\
\text { grants }\end{array}$ & (competitive grants outlays / obligations)x100 \\
\hline Implementation pace of total grants & (total grants outlays / obligations)x100 \\
\hline
\end{tabular}

Following prior studies (e.g., Carley et al., 2015; Hou et al., 2003; McDermott, 2006) — in which GC was essential to policy implementation and performance-I assert that independent variables are components of GC. In terms of ARRA grants, quickly spending grant funds is an indicator of success in grant implementation. For speedy implementation, governments need sufficient human resources, money, and relevant experience. Thus, the present study assumes that higher capacity governments will spend grant funds faster than lower capacity governments. The operationalization methods for GC are the same as in the first question's model, as described in Table 13.

Table 13 Government capacity measurement

\begin{tabular}{l|l}
\hline Variable & Measurement \\
\hline $\begin{array}{l}\text { Human resource capacity1: size of } \\
\text { human resource } \\
\text { human resource capacity2: quality of }\end{array}$ & $\begin{array}{l}\text { Number of DOT employees per 1000 residents } \\
\text { Total amount of DOT Payrolls / number of DOT } \\
\text { employees / state median income x 100 }\end{array}$ \\
\hline Financial resource capacity & $\begin{array}{l}\text { Transportation revenue (motor fuel taxes, motor } \\
\text { vehicle taxes, and charges)/ residents }\end{array}$ \\
\hline General management capacity & $\begin{array}{l}\text { GPP (government performance project) } \\
\text { infrastructure scores } \\
\text { Amount of federal grants }\end{array}$ \\
\hline
\end{tabular}


In the scholarly research, determinants of expenditure include: state needs, political variables (Alt \& Lowry, 1994; Hou \& Smith, 2010), and fiscal institution (Amiel et al., 2009; Deller et al., 2012; Mullins \& Wallin, 2004). Indicators of state needs are the same as those in the first research question's model, as seen in Table 14. Urbanization, economic condition, and median voters are assumed to affect government expenditure or policies on government spending.

Table 14 State needs measurement

\begin{tabular}{l|l}
\hline Variable & Measurement \\
\hline Urbanization & Population density/100 \\
Economic condition & Unemployment rate \\
Median voters & Median income/1000 \\
\hline
\end{tabular}

Following prior research, this present study adopts political variables and fiscal institutions as explanatory variables for grant implementation, as described in Table 15. Political variables include each governor's political propensity, divided government, and party control in the legislature. They are all coded as dummy variables. Governor's political propensity is coded as the political party affiliation of governor; I assigned a value of 1 to Republican governors, and zero otherwise. Divided government has a value of 1 if the governor's political party controls both houses in the legislature, and zero otherwise. For party control of legislature, I coded a value of 1 when the Republican Party occupies the majority in legislature, and zero otherwise. 
Table 15 State politics measurement

\begin{tabular}{l|l}
\hline Variable & Measurement \\
\hline Governor's propensity & Republican=1, otherwise=0 \\
Divided government & $1=$ governor's party controls both houses, $0=$ otherwise \\
Party control of legislature & Republican is majority party=1, otherwise $=0$ \\
\hline
\end{tabular}

The study uses tax and expenditure limitation (TEL) and balanced budget requirement as proxies for fiscal institutions as described in Table 16. First, data of TELs originate from previous research: Amiel et al. (2009). The authors developed the TEL stringency index with six categories: “1) the type of TEL; 2) if the TEL is statutory or constitutional; 3) growth restrictions; 4) method of TEL approval; 5) override provisions; and 6) exemptions” (p.5). Its values were coded as an interval scale, so readers can interpret it as State A is more stringent than State B, but cannot interpret it as State A is "many times" stricter than State B. Maher and Deller (2012) reported that TELs positively affect fund balance, but negatively affect own-source revenue and general fund expenditure. Second, generally, the balanced budget requirement (BBR) is also used as a proxy for fiscal institution in expenditure studies. However, BBR is not directly applied to capital investment or transportation, because it is funded mostly from other funds beyond general funds. Nevertheless, BBR is controlled in the analytic models since it influences the entire budget allocation and could affect transportation expenditure.

Table 16 Stringency of Tax and Expenditure Limit and of Balanced Budget Requirements

\begin{tabular}{l|l}
\hline Variable & Measurement \\
\hline Stringency of & $\begin{array}{l}\text { Summation of values of TELs: 1) the type of TEL; 2) if the TEL is } \\
\text { TELs }\end{array}$ \\
& $\begin{array}{l}\text { statutory or constitutional; 3) growth restrictions; 4) method of TEL } \\
\text { approval; 5) override provisions; and 6) exemptions }\end{array}$ \\
\hline Stringency of & $\begin{array}{l}\text { Sum of BBRs (Governor Must Submit Balanced Budget, Legislature Must } \\
\text { BBRs }\end{array}$ \\
\hline
\end{tabular}


The present study utilizes multiple sources for data collection, including Recovery.gov, Annual Survey of Public Employment \& Payroll, National Conference of State Legislatures, USAspending.gov, the Book of States, U.S. Census, etc. Detailed information of each variable is described in Table 17 below. All explanatory variables reflect values in 2008-2011.

Table 17 Data source

\begin{tabular}{|c|c|c|}
\hline \multicolumn{2}{|l|}{ Variable } & \multirow{2}{*}{$\begin{array}{l}\text { Source } \\
\text { Recovery.gov }\end{array}$} \\
\hline $\begin{array}{l}\text { Grant } \\
\text { Implementation }\end{array}$ & $\begin{array}{l}\text { Implementation pace of formula and } \\
\text { competitive grants }\end{array}$ & \\
\hline $\begin{array}{l}\text { Government } \\
\text { Capacity (GC) }\end{array}$ & $\begin{array}{l}\text { Human resource capacity1: size of human } \\
\text { resource } \\
\text { Human resource capacity2: quality of human } \\
\text { resource } \\
\text { Financial resource capacity: transportation } \\
\text { revenue } \\
\text { General management capacity: policy } \\
\text { experience for infrastructure management } \\
\text { Previous experience: policy experience for } \\
\text { grant }\end{array}$ & $\begin{array}{l}\text { Annual Survey of } \\
\text { Public Employment } \\
\text { \& Payroll } \\
\text { Book of States and } \\
\text { Census Bureau } \\
\text { GPP report } 2008 \\
\text { USAspending.gov }\end{array}$ \\
\hline State Needs & $\begin{array}{l}\text { Urbanization } \\
\text { Economic condition } \\
\text { Median voters }\end{array}$ & $\begin{array}{l}\text { Census Bureau } \\
\text { Bureau of Labor } \\
\text { Statistics } \\
\text { Census Bureau }\end{array}$ \\
\hline State Politics & $\begin{array}{l}\text { Governor’s propensity } \\
\text { Divided government } \\
\text { Party control of legislature }\end{array}$ & $\begin{array}{l}\text { National Conference } \\
\text { of State Legislatures }\end{array}$ \\
\hline $\begin{array}{l}\text { Fiscal } \\
\text { Institution }\end{array}$ & $\begin{array}{l}\text { TELs } \\
\text { BBRs }\end{array}$ & $\begin{array}{l}\text { Amiel et al. (2009) } \\
\text { NCSL (2010) }\end{array}$ \\
\hline
\end{tabular}




\subsection{Grant impact: Research Question, Method, and Data}

\subsubsection{Research question}

The research question in this chapter is "To what extent did ARRA grant aid affect the transportation expenditure recovery and state transportation investments?" Due to the Great Recession, state governments were confronted with diminished revenue; the severe economic downturn included factors ranging from the collapse of the housing market to weakened stock markets. According to the State Expenditure Report 2009 by NASBO, during FY 2008 and FY 2009, “state revenues decreased nearly 12 percent, or by $\$ 78.5$ billion” (NASBO, 2009). Consequently, there were declines in state funds (general funds and other state funds) for expenditure. However, neither all funds nor total funds decreased.

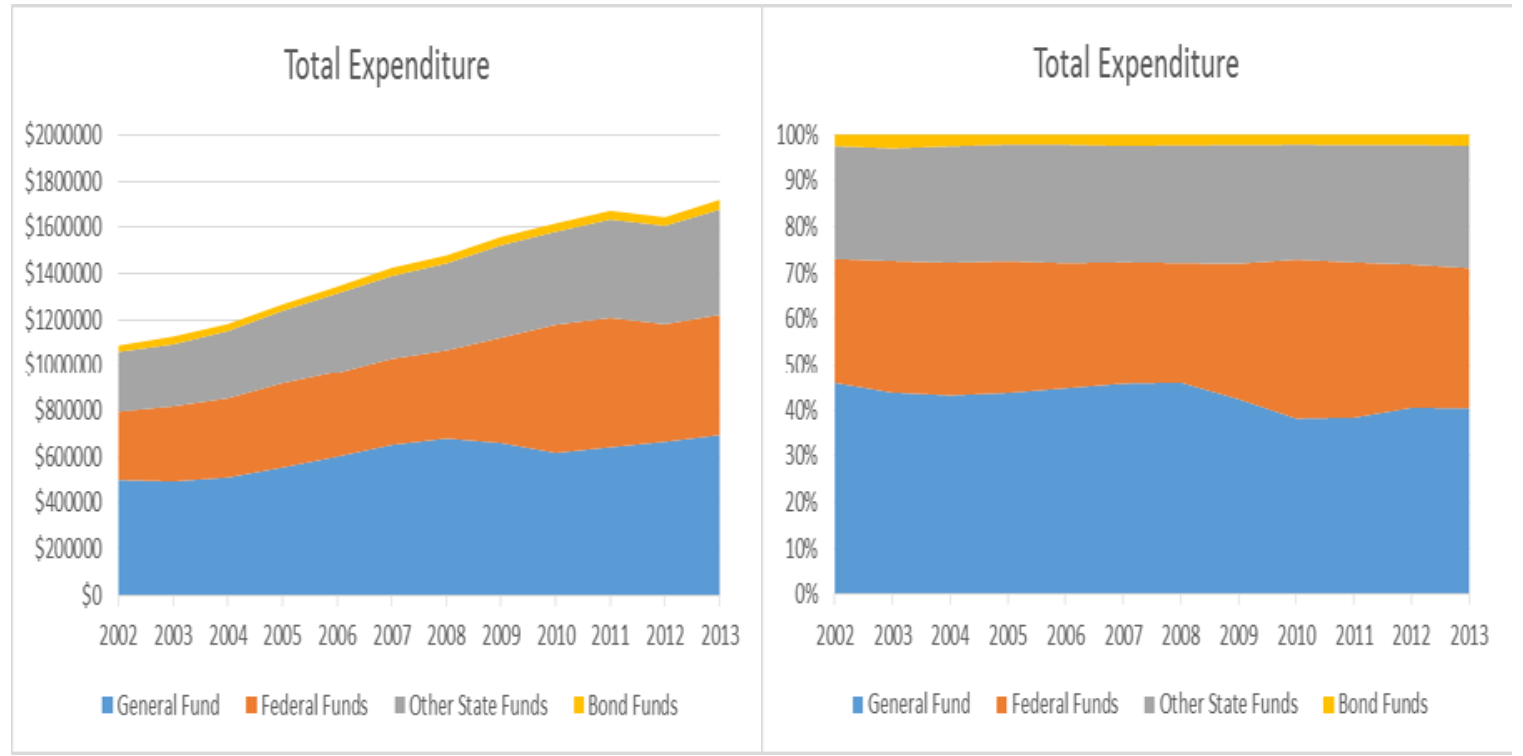

Figure 7 Total Expenditure trend 
As seen in Figure 7, in fact, expenditures from total funds increased, in which federal grant (e.g., ARRA) influx sharply increased in FY 2009 and FY 2010 and incited states to continue to increase spending. However, the size of increase rate was modest compared to the historical average annual increase rate of total state expenditures: $6.2 \%$. In FY 2009, total state expenditures increased by 5.4\% (\$1.56 trillion); in FY 2010, the increase rate was 4\% (\$1.62 trillion); in FY 2011, the total amount climbed to \$1.69 trillion, 4.1\% (NASBO, 2010). Thus, in the severe situation caused by the Great Recession—in which state funds declined due to economic shock—federal aid sustained states to continue spending.

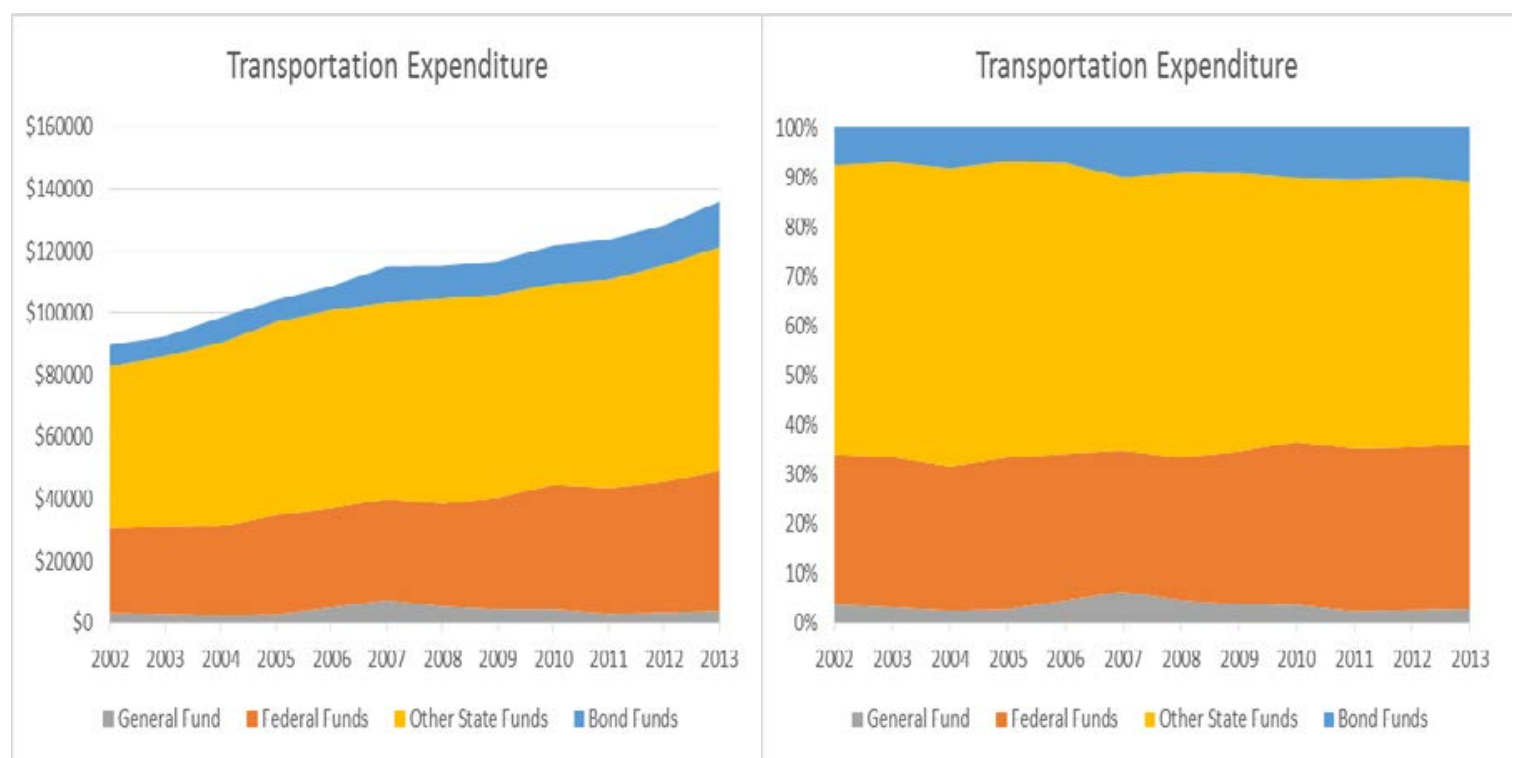

Figure 8. Transportation Expenditure trend

This dissertation focuses on transportation expenditure. As shown in Figure 8 below, states increased their transportation expenditure by 4.3\% in FY 2009 and by $6.5 \%$ 
in FY 2010. The increase of expenditure resulted from the impact of the federal fund influx. Thus, the present study investigates the degree to which ARRA grants stimulated states to spend funds on transportation since the Great Recession. I also check if government capacity affects state expenditure, controlling other determinants on expenditure.

\subsubsection{Modeling grant impact}

To answer the third research question, I developed a research model, setting the

dependent variable as a function of ARRA grants, government capacity, state needs, and state politics, fiscal institution, and legislature control.

Expenditure Recovery (or Expenditure)

$=\mathrm{f}$ (ARRA grant, government capacity, state needs, state politics, fiscal institution, legislature control)

The study assumes that the equation is composed by linear combination, and the function is expressed in the mathematical form,

$$
Y_{i t}=\alpha+\beta_{\mathrm{i}} G C_{i t-1}+\gamma_{\mathrm{i}} S P_{i t-1}+\delta_{\mathrm{i}} S N_{i t-1}+\theta F I_{i t-1}+\tau L C_{i t-1}+\varepsilon,
$$

where $\mathrm{Y}$ is expenditure recovery or expenditure, GC is government capacity, SP indicates state politics, SN means state needs, FI represents fiscal institution, and LC is legislature control. 


\subsubsection{Data and variables}

The unit of analysis is the Department of Transportation in the 50 U.S. states. ${ }^{36}$ Data analysis covers the time range from 2009 to 2011 to investigate the impact of grants after ARRA.

Regarding the expenditures of state governments, I adopted two dependent variable groups. One variable is the transportation expenditure recovery. To test ARRA funds' effects on recovery of subnational expenditure, the study devises it. Because ARRA was initiated in FY 2009, FY 2008 is used as the starting point to calculate the degree of expenditure restoration. So, the difference between expenditure in FY 2008 (subtrahend) and in each fiscal year 2009-2011 (minuend) is regarded as the amount of expenditure restoration. This model will indicate the extent that states increased expenditure since the last year (FY 2008) before ARRA. The other dependent variable is transportation investment. Aside from impact on expenditure recovery, I test how expenditure is affected by explanatory variables during the recovery period 2009-2011.

Both expenditure recovery and expenditure are categorized into total transportation expenditure, transportation capital outlays, and transportation current operation expenditure. The study assumes that capital outlays represent expenditures on construction, and current expenditures reflect maintenance expenditure. ${ }^{37}$ The

\footnotetext{
${ }^{36}$ In the real analysis, Nebraska was omitted because it does not have partisanship in the legislature.

37 According to the definitions of State Government Finances, capital outlay means “direct expenditure for contract or force account construction of buildings, grounds, and other improvements, and purchase of equipment, land, and existing structures. Includes amounts for additions, replacements, and major alterations to fixed works and structures." Current expenditure means "Current Expenditure. All expenditures with the exception of capital outlay. Includes Current Operations, Assistance and
} 
categorization of expenditures will be useful to investigate which expenditure was effectively affected by the federal aid.

State governments must spend funds on construction in accordance with the aims of the Recovery Act-investment (reinvestment) in transportation and infrastructurealbeit maintenance activities are also important. So, it is meaningful to check for different patterns across types of expenditure, regarding the effects of explanatory variables. All amounts were standardized by population and adjusted to real value in 2012 dollars. The specific measurements are presented below in detail (Table 18).

Table 18 Dependent variable of research question 3

\begin{tabular}{ll}
\hline Variables & Measurement \\
\hline $\begin{array}{l}\text { Expenditure recovery } \\
\text { (total, capital, and }\end{array}$ & $\begin{array}{l}\text { Transportation Expenditure in FY 2009, 2010, 2011 - } \\
\text { current) }\end{array}$ \\
& $\begin{array}{l}\text { Expenditure in FY 2008 } \\
\text { All expenditures are separately computed with State total } \\
\text { transportation, transportation capital outlay, transportation } \\
\text { current expenditure. }\end{array}$ \\
& All expenditures are standardized by 1000 state residents \\
\hline $\begin{array}{l}\text { Transportation } \\
\text { investment } \\
\text { (total, capital, and }\end{array}$ & Transportation Expenditure in FY 2009, 2010, 2011 \\
current) & All expenditures are separately computed with State total \\
& transportation, transportation capital outlay, transportation \\
& current expenditure. \\
\hline
\end{tabular}

The explanatory variables are the amount of the two types of grant per capita, as well as government capacity, state needs, state politics, fiscal institution, and legislature control on DOT. First, I test impact of ARRA grants. The theoretical background for grant

Subsidies, interest on debt, and Insurance Benefits and Repayments.” Expenditures for repairs, such as works and structures, are "classified as current operation expenditure.” 
effects on expenditures is the flypaper effect-which originates from the literature on public finance. The implication of the flypaper effect is that, for increases of expenditure, the effects of grants are greater than the effects of income (Fisher, 2007, p. 218). Although the flypaper effect initially emerged as an explanation for the effects of lump-sum grants, it has also been used for other types of grants. Most research that accounts for the flypaper effect suggests that federal grants increase subnational government expenditures (e.g., Nesbit \& Kreft, 2009). However, some research reports that these grants induce crowdingout effects on the governments (e.g., Knight, 2002). Therefore, the present study uses ARRA grants as an independent variable —and tests how and how much the independent variable affects expenditure recovery and investment. To compare impacts of the two granttypes, I distinguished and entered both discretionary and formula grants in the regression models. As described in Table 19, ARRA grants per capita are measured by the outlay of grants per capita.

Table 19 Operationalization of grants

\begin{tabular}{ll}
\hline Variables & Measurement \\
\hline ARRA grants per capita & $\begin{array}{l}\text { Outlay of competitive and formula grants per capita } \\
\text { (FY2009-2011) }\end{array}$ \\
\hline
\end{tabular}

Second, referring to previous studies (e.g., Carley et al., 2015; Hou et al., 2003; McDermott, 2006) asserting that higher capacity governments are more likely to succeed in policy performance, the present study assumes that governments with higher capacity would perform better in the utilization of federal grants to invest in construction rather than maintenance. In contrast, due to the timeline limits of ARRA grants, lower capacity 
governments that are less proficient at mid-term planning, and do not have sufficient resources, may use the grants mostly in the maintenance function.

Third, in terms of legislature control of DOT, push-factors and pull-factors affect expenditure size. According to Niskanen’s budget-maximization model, bureaucracies are incentivized to expand budgets due to the interests of their organizations. In the Iron Triangle model, alliances exist between bureaucracy and committee members of the legislature. Moreover, Bureaucratic Politics model also assumes the existence of such alliances (e.g., instances where bureaucrats allocate funds for politicians who previously supported DOT—as a gratitude) (Rich, 1989). Meanwhile, the legislature may hinder bureaucratic spending. Every state has an oversight system in which each committee controls and collaborates with DOT not only during the session but also during out-ofsession periods. Thus, the present study advances an index of legislature control using survey data from AASHTO (American Association of State Highway and Transportation Officials) $)^{38}$, and tests how this index affects DOT expenditure.

To estimate the legislature control index, I utilized principal component analysis, as seen in Table 20. From the analysis, we can store factor scores and variance values. By using the variance values as weighting for each component, we can calculate total value of

\footnotetext{
${ }^{38}$ AASHTO survey has "interactions b/w DOT \& legislature data" part with 13 questions and answers in terms of oversight mechanisms over DOT, review authority over DOT rules, and legislative role in surplus funds, reallocations, PPPs, and design-build. Examples of the 13 Survey Questions are: Ongoing oversight by legislative committee (1/0), Legislature performs program reviews or performance audits (1/0), Legislature reviews non-legislative programs or performance audits (1/0), DOT Reporting Requirements to the Legislature and/or Legislative Committee (1/0), Legislature requests information from the DOT(1/0), Is the DOT authorized to retain surplus funds? (1/0), Is legislative approval required to move funds between projects? (1/0)
} 
the interaction, which is computed with the summation of product of a weighing and a factor score, by each state.

$$
\text { Legislature Control }_{i}=\mathrm{W}_{\mathrm{m}} \sum_{\mathrm{i}=1}^{50} \mathrm{~F}_{\mathrm{mi}}
$$

where i means each state, $\mathrm{W}$ is a weighting, $\mathrm{m}$ indicates each component, and $\mathrm{F}$ means a factor score.

Table 20 Operationalization of relation between state DOT and legislature

\begin{tabular}{ll}
\hline Variables & Measurement \\
\hline Legislature control & Factor analysis from 13 questions \\
\hline
\end{tabular}

The study collected data from multiple sources, including Recovery.gov, Annual Survey of Public Employment \& Payroll, National Conference of State Legislatures, USAspending.gov, the Book of States, U.S. Census, etc. Detailed information of each variable is described in the Table 21 below. All explanatory variables reflect values in 2008-2010. 
Table 21 Data source

\begin{tabular}{|c|c|c|}
\hline \multicolumn{2}{|l|}{ Variable } & \multirow{3}{*}{$\begin{array}{l}\text { Source } \\
\text { U.S. Census (State } \\
\text { Government } \\
\text { Finances) }\end{array}$} \\
\hline $\begin{array}{l}\text { Expenditure } \\
\text { Recovery }\end{array}$ & $\begin{array}{l}\text { Expenditure recovery on total transportation, } \\
\text { transportation capital outlays, transportation } \\
\text { current operation expenditure }\end{array}$ & \\
\hline $\begin{array}{l}\text { Transportation } \\
\text { investment }\end{array}$ & $\begin{array}{l}\text { Expenditure on total transportation, } \\
\text { transportation capital outlays, transportation } \\
\text { current operation expenditure }\end{array}$ & \\
\hline ARRA grant & ARRA competitive and formula grant & Recovery.gov \\
\hline $\begin{array}{l}\text { Government } \\
\text { Capacity (GC) }\end{array}$ & $\begin{array}{l}\text { Human resource capacity1: size of human } \\
\text { resource } \\
\text { Human resource capacity2: quality of human } \\
\text { resource } \\
\text { Financial resource capacity: transportation } \\
\text { revenue } \\
\text { General management capacity: policy } \\
\text { experience for infrastructure management } \\
\text { Previous experience: policy experience for } \\
\text { grant }\end{array}$ & $\begin{array}{l}\text { Annual Survey of } \\
\text { Public Employment } \\
\text { \& Payroll } \\
\text { Book of States and } \\
\text { Census Bureau } \\
\text { GPP report } 2008 \\
\text { USAspending.gov }\end{array}$ \\
\hline State Needs & $\begin{array}{l}\text { Urbanization } \\
\text { Economic condition } \\
\text { Median voters }\end{array}$ & $\begin{array}{l}\text { Census Bureau } \\
\text { Bureau of Labor } \\
\text { Statistics } \\
\text { Census Bureau }\end{array}$ \\
\hline State Politics & $\begin{array}{l}\text { Governor's propensity } \\
\text { Divided government } \\
\text { Party control of legislature }\end{array}$ & $\begin{array}{l}\text { National Conference } \\
\text { of State Legislatures }\end{array}$ \\
\hline $\begin{array}{l}\text { Fiscal } \\
\text { Institution }\end{array}$ & $\begin{array}{l}\text { TELs } \\
\text { BBRs }\end{array}$ & $\begin{array}{l}\text { Amiel et al. (2009) } \\
\text { NCSL (2010) }\end{array}$ \\
\hline $\begin{array}{l}\begin{array}{l}\text { Legislature } \\
\text { control }\end{array} \\
\end{array}$ & Index of legislature control & $\begin{array}{l}\text { AASHTO survey, } \\
\text { author's computation }\end{array}$ \\
\hline
\end{tabular}




\section{Chapter V. EMPIRICAL RESULT}

Chapter V presents empirical results according to the three research questions on ARRA transportation grant acquisition, implementation, and impact. This chapter includes two sections: (1) descriptive results of all dependent variables and (2) regression results for each analytic model.

\subsection{Descriptive results}

Prior to the presentation of regression results, this section sets forth descriptive results dependent variables by each research question. Each table below includes rankings in the first column, a list of states ordered by ranking, and values of each variable. In the tables, top five and bottom five states were selected for instance of the variables.

Table 22 Descriptive results of grant acquisition (2011)

\begin{tabular}{c|cc|cc}
\hline Ranking & State & per capita (\$) & State & Total(\$ million) \\
\hline 1 & WA & 137.05 & CA & 3419.94 \\
2 & IL & 134.30 & IL & 1726.87 \\
3 & AK & 124.14 & WA & 935.00 \\
4 & VT & 104.74 & NY & 837.86 \\
5 & CA & 90.71 & NC & 566.18 \\
\hline 46 & KS & 6.01 & WY & 14.58 \\
47 & VA & 4.16 & ND & 11.83 \\
48 & GA & 3.91 & ID & 10.95 \\
49 & NH & 3.31 & NH & 4.37 \\
50 & DE & 2.65 & DE & 2.41 \\
\hline
\end{tabular}


Table 22 ranks states in order of the amount of the acquired transportation grants, California secured \$ 3419.94 million and was ranked first place. Illinois follows as the second state that acquired more grants. Meanwhile, Delaware was the lowest state that obtained the smallest amount of grant dollars, \$ 2.41 million.

Table 23 Descriptive results of grant implementation (2011)

\begin{tabular}{c|cc|cc|cc}
\hline Ranking & State & Competitive (\%) & State & Formula (\%) & State & Total (\%) \\
\hline 1 & NE & 100 & SD & 99.26111 & UT & 99.31421 \\
2 & NH & 100 & ME & 99.11671 & SD & 99.22146 \\
3 & UT & 99.85898 & WY & 99.11353 & WY & 98.96432 \\
4 & SD & 98.876 & UT & 99.09926 & NH & 98.05435 \\
5 & ND & 98.25278 & MT & 98.73051 & ND & 97.60734 \\
46 & RI & 14.2821 & GA & 73.76883 & HI & 58.65316 \\
47 & WA & 13.54395 & NY & 72.65414 & NC & 57.05924 \\
48 & IL & 10.73007 & FL & 71.65395 & WA & 48.61869 \\
49 & NC & 10.30709 & VA & 65.18724 & IL & 46.32236 \\
50 & CA & 10.21289 & HI & 55.67302 & CA & 45.86135 \\
\hline
\end{tabular}

Regarding the second research question of grant implementation, Table 23 sorts states by three variables: competitive grant, formula grant, and total grant. Overall, Utah and South Dakoda were ranked in the top five cluster for all grant categories. Whereas California, Washington, and North Carolina, which acquired larger grants, were ranked in the bottom five group. It infers that there is a negative association between the amount of the grant and the implementation rate. 
There is a large variation of expenditure recovery across the top and bottom clusters, as described in Table 24. For example, North Dakoda and South Dakoda recovered the level of transportation capital outlays much better than Kentucky and Florida. As explained in connection with Table 23, overall, good performers in grant implementation, such as SD and ND, are likely to be good at expenditure recovery.

Table 24 Descriptive results of expenditure recovery (per capita \$, 2011)

\begin{tabular}{c|cc|cc|cc}
\hline Ranking & State & Total & State & Capital & State & Current \\
\hline 1 & ND & 322.1045 & ND & 217.9644 & AK & 58.40176 \\
2 & SD & 177.8293 & SD & 175.5382 & ND & 57.47378 \\
3 & VT & 174.8483 & VT & 166.759 & TN & 40.66714 \\
4 & OK & 124.8836 & UT & 133.3282 & MN & 34.16666 \\
5 & ME & 123.8625 & ME & 131.2376 & AL & 25.17232 \\
\hline 46 & GA & -86.8751 & GA & -82.7672 & MA & -28.9669 \\
47 & HI & -104.757 & TX & -90.4364 & NM & -50.9843 \\
48 & MD & -119.458 & AK & -109.842 & MD & -59.3707 \\
49 & FL & -130.097 & FL & -110.874 & VA & -59.8894 \\
50 & KY & -165.45 & KY & -163.135 & WY & -77.9645 \\
\hline
\end{tabular}

Table 25 presents the pattern across three variables, in which bolded states are examples to show the pattern. The top five states in total grant acquisition, such as CA, IL, WA, NY, and NC, tend to implement grants slowly. It implies that a higher level of grant acquisition would increase task complexity regarding grant implementation. Moreover, a higher level of implementation performance seems to contribute to a higher level of 
expenditure recovery. For example, SD, ND, and UT were ranked in the higher position of the implementation category, and they were also included in the top five group of expenditure recovery.

Table 25 Comparison of states in three stages of ARRA

\begin{tabular}{c|cc|ccc|ccc}
\hline \multirow{2}{*}{ Ranking } & Grant Acquisition & \multicolumn{3}{|c|}{ Implementation } & \multicolumn{2}{|c}{ Expenditure recovery } \\
\cline { 2 - 8 } & per capita & Total & Competitive & Formula & Total & Total & Capital & Current \\
\hline 1 & WA & CA & NE & SD & UT & ND & ND & AK \\
2 & IL & IL & NH & ME & SD & SD & SD & ND \\
3 & AK & WA & UT & WY & WY & VT & VT & TN \\
4 & VT & NY & SD & UT & NH & OK & UT & MN \\
5 & CA & NC & ND & MT & ND & ME & ME & AL \\
\hline 46 & KS & WY & RI & GA & HI & GA & GA & MA \\
47 & VA & ND & WA & NY & NC & HI & TX & NM \\
48 & GA & ID & IL & FL & WA & MD & AK & MD \\
49 & NH & NH & NC & VA & IL & FL & FL & VA \\
50 & DE & DE & CA & HI & CA & KY & KY & WY \\
\hline
\end{tabular}




\subsection{Regression results}

This section includes three subsections according to the three research questions on ARRA transportation grant acquisition, implementation, and impact. Each subsection presents interpretations on descriptive statistics and regression statistics.

\subsubsection{Grant acquisition}

The first research question examines the effect of state government capacity on ARRA grant competition, controlling for other plausible factors that might affect grant allocation. To test the effect, I estimate the models using the dependent variable (i.e., amount of grants allocated to states by the federal DOT and its agencies) and explanatory variables encompassing government capacity components, federal politics variables, and state needs factors.

First, Table 26 presents descriptive statistics. The mean of the total obligated discretionary grants is $\$ 215.13$ million; the standard deviation, $\$ 547.20$ million, is larger than the mean—reflecting significant variation across states in the acquisition of grants. The number of DOT full-time employees per 1000 residents is 1.23 on average, and the largest number is 4.37. Details for the other variables are presented in the table below. 
Table 26 Descriptive statistics

\begin{tabular}{|c|c|c|c|c|}
\hline Variable & Mean & $\begin{array}{l}\text { Std. } \\
\text { Dev. }\end{array}$ & Min & Max \\
\hline $\begin{array}{l}\text { Total amount of obligated competitive } \\
\text { grants in } \$ \text { million }\end{array}$ & 215.13 & 547.20 & 2.409 & 3419.9 \\
\hline Log (amount of competitive grants) & 4.23 & 1.36 & 0.88 & 8.14 \\
\hline $\begin{array}{l}\text { Human resource capacity1: size of human } \\
\text { resource }\end{array}$ & 1.23 & 0.78 & 0.27 & 4.37 \\
\hline $\begin{array}{l}\text { Human resource capacity2: quality of } \\
\text { human resource }\end{array}$ & 8.139 & 1.238 & 6.026 & 12.399 \\
\hline $\begin{array}{l}\text { Financial resource capacity: transportation } \\
\text { revenue }\end{array}$ & 0.2689 & 0.0695 & 0.168 & 0.442 \\
\hline $\begin{array}{l}\text { General management capacity: policy } \\
\text { experience for infrastructure management }\end{array}$ & 7.9 & 1.87 & 4 & 12 \\
\hline $\begin{array}{l}\text { Previous experience: policy experience for } \\
\text { grant }\end{array}$ & 23.75 & 33.86 & 2.58 & 183.27 \\
\hline House Appropriations Committee 1 & 1.34 & 1.65 & 0 & 7 \\
\hline House Transportation Committee 2 & 1.48 & 1.72 & 0 & 7 \\
\hline Urbanization & 1.92 & 2.57 & 0.01 & 11.74 \\
\hline Median voters & 50.7 & 7.87 & 36.45 & 66.18 \\
\hline Economic condition & 5.28 & 1.27 & 3 & 8.3 \\
\hline
\end{tabular}

Note. The number of observations for all variables is 50 . The statistics of all explanatory variables represent values in FY2008

Second, Table 27 presents the result of the log-linear regression model with Ordinary Least Squares (OLS) estimator, which includes the six components of GC, two political variables, and three environmental factors in order to estimate the effect of each. According to the F-test (prob $>\mathrm{F}=0.000$ ), the null hypothesis that all coefficients are jointly zero is rejected. The adjusted R-squared indicates that this model explains $69 \%$ of the variation in the dependent variable. In addition, the model is tested to check for issues of multicollinearity, heteroskedasticity, and omitted variable. The Variance Inflation Factor 
$(\mathrm{VIF})^{39}$ indicates "the degree to which the variance has been inflated because regressor $\mathrm{k}$ is not orthogonal to the other regression” (Baum, 2006, p. 85), and if the largest value of VIF is smaller than 10 , the probability of a collinearity problem is low. In the model, all VIF is smaller than 3.2, indicating no evidence of multicollinearity. Moreover, the BreuschPagan / Cook-Weisberg test is run for heteroskedasticity ${ }^{40}$, in which the null hypothesis that assumes constant variance is not rejected. Finally, according to the Ramsey RESET test ${ }^{41}$, the null hypothesis that assumes no omitted variables in the model is also not rejected.

Turning to the effects of the explanatory variables in Table 27, the components of GC—human resource capacity $1 \& 2$ and general management capacity—are associated with grant acquisitions of state governments. Other components do not indicate significant effects.

The two human resource capacity components indicate different effects on the amount of grants. Human resource capacity 2-quality of human resource, measured by payrolls of full-time DOT employees compared to state median income-is statistically and positively significant for acquiring grants. In other words, governments that have higher quality labor forces, or treat their employees generously, are more likely to acquire larger grants. Specifically, the expected change in log of ARRA grant increases by 0.4655 with respect to a one-unit change of human resource capacity 2, holding all other variables constant. In other words, the one-unit change of human resource 2 augments ARRA grant

\footnotetext{
39 Stata syntax is vif.

40 Stata syntax is hettest, iid. In the result, chi2(1) $=0.18$, Prob $>$ chi2 $=0.6707$

${ }^{41}$ Stata syntax is ovtest. In the result, $F(3,36)=0.47$, Prob $>F=0.7047$
} 
acquisition by $59.28 \%$. However, human resource capacity 1 -size of the human resource - has negative effects on grant acquisition. Per additional unit change of the size of full-time employees, the amount of grants decreases approximately by $45.23 \%$, calculated by $100 \times\left(\mathrm{e}^{-0.602}-1\right)$. This implies that a large government does not have an advantage in acquiring grants. Meanwhile, the results indicate previous experience is positively significant on grant competition, which means states that acquired more grants than other states are likely to obtain ARRA grants.

Table 27 Predicting the Effect of Government Capacity on Grant Acquisition

\begin{tabular}{|c|c|c|c|}
\hline & Coef. & S.E. & $\begin{array}{l}\text { Standardized } \\
\text { Beta Coef. }\end{array}$ \\
\hline $\begin{array}{l}\text { Human resource capacity1: size of human } \\
\text { resource }\end{array}$ & $-0.602 * * *$ & 0.190 & -0.345 \\
\hline $\begin{array}{l}\text { Human resource capacity2: quality of human } \\
\text { resource }\end{array}$ & $0.4655 * * *$ & 1.245 & 0.423 \\
\hline $\begin{array}{l}\text { Financial resource capacity: transportation } \\
\text { expenditure }\end{array}$ & -0.007 & 2.150 & -0.000 \\
\hline $\begin{array}{l}\text { General management capacity: policy } \\
\text { experience for infrastructure management }\end{array}$ & 0.075 & 0.065 & 0.102 \\
\hline $\begin{array}{l}\text { Previous experience: policy experience for } \\
\text { grant }\end{array}$ & $0.014 * * *$ & 0.005 & 0.336 \\
\hline House Appropriations Committee & -0.123 & 0.120 & -0.149 \\
\hline House Transportation Committee & $0.293^{* * *}$ & 0.099 & 0.369 \\
\hline Urbanization & -0.035 & 0.054 & -0.066 \\
\hline Economic condition & 0.038 & 0.127 & 0.353 \\
\hline Median voters & 0.025 & 0.019 & 0.142 \\
\hline Constant & -1.380 & 1.702 & \\
\hline $\begin{array}{l}\text { Number of Observations } \\
\text { Prob }>\mathrm{F} \\
\text { Adjusted R-squared }\end{array}$ & $\begin{array}{l}50 \\
0.000 \\
0.6813 \\
\end{array}$ & & \\
\hline
\end{tabular}

*** $\mathrm{p}<0.01,{ }^{* *} \mathrm{p}<0.05,{ }^{*} \mathrm{p}<0.1$

50 states. All regressors reflect values in 2008 
In terms of control variables, the results show that political factors do shape the outcome of grant competitions. Consistent with prior research, we find support for the Pork Barrel hypothesis, which has been discussed and tested in a number political science studies. Members of the House Committee on Transportation are likely to exercise their political leverage to benefit their own states, as suggested by the positive and statistically significant coefficient of the House Transportation Committee variable. Yet, representatives sitting on the Appropriations Committee do not seem to exercise much influence on the outcomes of grant competitions. The other control variables are not statistically significant.

Admittedly, arguments of public administration and political science do make sense, according to the results that show statistical significance of GC and federal politics variables. So, the present study intends to demonstrate which factor has greater effects on ARRA grant competition. Standardized beta coefficients can facilitate this objective, as the beta coefficient of each explanatory variable indicates how many standard deviations of the dependent variable would change given one standard deviation change in independent variables. Thus, the beta coefficient of human resource capacity $2(0.423)$ is larger than the beta coefficient of the Transportation Committee variable (0.369), which implies that the impact of GC is greater than the impact of federal politics in grant competition. 


\subsubsection{Grant Implementation}

The second research question concerns grant implementation. This study investigates whether states did right to meet the purpose of the ARRA grants, which aimed to facilitate economic recovery through government expenditure and rapid spending by recipient governments. Consequently, I tested if government capacity played an important role in the pacing of grant implementation.

To test this research question, I set three dependent variables: total grant implementation rate, discretionary grant implementation rate, and formula grant implementation rate. As presented in Table 28, total grant implementation rates, which were calculated as ARRA grant outlays over obligations and expressed as percentage points, have a mean value of $71.77 \%$ and standard deviation of $27.24 \%$. The implementation rate of discretionary grants is $63.53 \%$ (mean) and the rate of formula grants is $75.65 \%$, which

indicate that state governments more easily spent formula grants, compared to discretionary grants.

Aside from variables that were used in the grant acquisition model, several variables that affect government spending were controlled. Republican governors occupy half of the 50 states. Divided governments, in which the governor's political party did not control both houses in the legislature, existed in less than 25 states. The percentage of states with Republican-controlled legislatures was 38\%. Fiscal institutions, such as TELs, were also utilized to predict the ARRA grant implementation rate. 
Table 28 Descriptive statistics on Grant Implementation (2009-2012)

\begin{tabular}{lllll}
\hline Variable & Mean & $\begin{array}{l}\text { Std. } \\
\text { Dev. }\end{array}$ & Min & Max \\
\hline Total Implementation & 71.77 & 27.24 & 4.32 & 100 \\
Discretionary Grant Implementation & 63.53 & 30.14 & 0 & 100 \\
Formula Grant Implementation & 75.65 & 28.62 & 3.75 & 100 \\
$\begin{array}{l}\text { Human resource capacity1: size of human } \\
\text { resource }\end{array}$ & 1.18 & 0.77 & 0.24 & 4.37 \\
$\begin{array}{l}\text { Human resource capacity2: quality of } \\
\text { human resource }\end{array}$ & 8.439 & 1.303 & 5.86 & 12.889 \\
$\begin{array}{l}\text { Financial resource capacity: transportation } \\
\text { revenue }\end{array}$ & 0.261 & 0.072 & 0.157 & 0.558 \\
$\begin{array}{l}\text { General management capacity: policy } \\
\text { experience for infrastructure management }\end{array}$ & 7.9 & 1.85 & 4 & 12 \\
$\begin{array}{l}\text { Previous experience: policy experience for } \\
\text { grant }\end{array}$ & 30.02 & 48.86 & 0 & 411.77 \\
Urbanization & 194.34 & 257.36 & 1.20 & 1196.71 \\
Median voters & 50.537 & 7.929 & 35.078 & 71.122 \\
Economic condition & 7.57 & 2.18 & 3 & 13.8 \\
$\begin{array}{l}\text { Governor's propensity (Republican) } \\
\begin{array}{l}\text { Divided government } \\
\text { Republican legislature }\end{array}\end{array}$ & 0.5 & 0.50 & 0 & 1 \\
$\begin{array}{l}\text { TELs } \\
\text { BBRs }\end{array}$ & 0.43 & 0.50 & 0 & 1 \\
\hline & 8.34 & 7.88 & 0 & 25 \\
\hline
\end{tabular}

Note. The number of observations for all variables is 200. The statistics of all explanatory variables represent one-year lagged values, except time-invariant variables (General management capacity, TEL, and BBR) 
To estimate models, I use the Panel Corrected Standard Error (PCSE) technique, because autocorrelation occurs in all models ${ }^{42}$ and heteroscedasticity occurs in Models $2^{43}$. PCSE is appropriate in this case because it allows me to account for the heteroscedasticity and autocorrelation problems in the data. Table 29 presents the regression results—using data covering 2009-2012—from three models with three dependent variables: discretionary grant implementation rate, formula grant implementation rate, and total grant implementation rate.

I start with the independent variables (i.e., the components of government capacity) to explain the regression results. First, the results show that human resource capacity $1-$ size of human resource-is positively and statistically significant on the dependent variables in Model 3. Specifically, one additional unit change in the number of DOT fulltime employees per 1000 residents increases the percentage point of implementation rate of total grants by approximately 5.15, holding other variables constant. Though discretionary grant implementation is affected by human resource capacity 1 , in which the coefficient is 2.544 , it is not statistically significant. Meanwhile, human resource capacity 2-which indicates the competence of DOT employees measured by the relative remuneration level compared to median income—-seems to have positive effects on grant implementation (formula and total grant); however, it is not statistically significant. Second,

\footnotetext{
42 Wooldridge test is conducted, in which the null hypothesis is that there is no first-order autocorrelation. Test results reveal the null hypotheses for all models are rejected, which means all models probably have the first-order autocorrelation.

${ }^{43}$ Breusch-Pagan / Cook-Weisberg test is run for checking the challenge of heteroskedasticity. The test reports Model 2 has the problem of heteroskedasticity, based on the results, chi2(1) $=0.00$ and Prob $>$ chi2 $=0.9790$.
} 
per capita transportation own source, as the proxy of financial resource capacity, is positively associated with formula and total grants and its effect is statistically significant. Third, general management capacity, reflecting infrastructure management, is the other GC component that has significant effect on formula grant implementation. In sum, greater size of administration, more revenue sources, and more experience in handling federal grants are likely to serve state governments well in rapid grant implementation.

One interesting point, which emerged from the empirical evidence of GC in all models, is the effect of financial resource capacity. As seen in Tables 29, financial resource capacity (transportation revenue) is associated only with formula and total grants. A possible explanation for why the positive effect of financial resource capacity is significant only in formula and total grants relates to the nature of funding system. Discretionary grants under ARRA are primarily for new projects and allocated by the review of applications; however, a formula grant is normally for current projects or maintenance, and is automatically distributed following the federal DOT's specified formula. So, the predictable fund (i.e., a formula-based grant) is likely statistically associated with the ratio of own source revenue-compared to the less predictable fund: competitive grant. Moreover, the amount of discretionary grant program is approximately one-tenth of formula-based grants, which means that discretionary grants would not likely have statistical relation with own source revenue. 
Table 29 Predicting the Effect of Government Capacity on Grant Implementation

\begin{tabular}{|c|c|c|c|c|c|c|}
\hline \multirow{2}{*}{ Implementation } & \multicolumn{2}{|c|}{ Discretionary(Model 1) } & \multicolumn{2}{|c|}{ Formula (Model 2) } & \multicolumn{2}{|c|}{ Total (Model 3) } \\
\hline & Coef. & S.E & Coef. & S.E & Coef. & S.E \\
\hline $\begin{array}{l}\text { Human resource } \\
\text { capacity1 }\end{array}$ & 2.544 & 4.037 & 1.989 & 2.875 & $5.153 * *$ & 2.303 \\
\hline $\begin{array}{l}\text { Human resource } \\
\text { capacity2 }\end{array}$ & -1.4374 & 2.556 & 1.6077 & 1.5278 & 0.7447 & 1.6702 \\
\hline $\begin{array}{l}\text { Financial resource } \\
\text { capacity }\end{array}$ & 5.947 & 39.64 & $192.67 * * *$ & 34.746 & $153.25^{* * *}$ & 34.309 \\
\hline $\begin{array}{l}\text { General } \\
\text { management } \\
\text { capacity }\end{array}$ & -2.104 & 1.439 & 1.013 & 1.427 & 1.297 & 0.824 \\
\hline $\begin{array}{l}\text { Previous } \\
\text { experience }\end{array}$ & 0.030 & 0.044 & $0.108^{* * *}$ & 0.035 & $0.103^{* *}$ & 0.050 \\
\hline Urbanization & $-0.041 * * *$ & 0.009 & $-0.042 * *$ & 0.018 & $-0.039 *$ & 0.021 \\
\hline $\begin{array}{l}\text { Economic } \\
\text { Condition }\end{array}$ & 1.180 & 1.027 & $12.125^{* * *}$ & 0.653 & $10.679 * * *$ & 2.029 \\
\hline Median voter & 0.395 & 0.302 & $0.541^{*}$ & 0.288 & $0.465^{*}$ & 0.246 \\
\hline $\begin{array}{l}\text { Republican } \\
\text { Governor }\end{array}$ & 4.855 & 4.285 & 1.468 & 2.865 & 2.970 & 2.056 \\
\hline $\begin{array}{l}\text { Divided } \\
\text { government }\end{array}$ & -0.713 & 4.077 & -3.353 & 2.686 & -3.173 & 2.891 \\
\hline $\begin{array}{l}\text { Republican } \\
\text { legislature }\end{array}$ & $10.551^{*}$ & 5.791 & $18.416^{* * *}$ & 3.746 & $19.327 * * *$ & 4.919 \\
\hline BBRs & 0.282 & 2.989 & $-4.964 * *$ & 2.324 & $-4.989 * *$ & 2.433 \\
\hline TELs & 0.145 & 0.168 & $-1.321 * * *$ & 0.279 & $-1.281 * * *$ & 0.241 \\
\hline Constant & $53.058 *$ & 31.48 & $-106.8 * * *$ & 24.982 & $-86.421 * *$ & 37.215 \\
\hline $\begin{array}{l}\text { Number of } \\
\text { Observations } \\
\text { Number of groups } \\
\mathrm{R}^{2} \\
\text { Prob> chi } 2\end{array}$ & $\begin{array}{l}196 \\
49 \\
0.6424 \\
0.000 \\
\end{array}$ & & $\begin{array}{l}196 \\
49 \\
0.5676 \\
0.000\end{array}$ & & $\begin{array}{l}196 \\
49 \\
0.6393 \\
0.000\end{array}$ & \\
\hline
\end{tabular}

Note. ${ }^{* * *} \mathrm{p}<0.01,{ }^{* *} \mathrm{p}<0.05,{ }^{*} \mathrm{p}<0.1$. S.E. indicates panel corrected standard error in Model $1 \& 3$, and heteroskedastic corrected standard error in Model 2. Time period: 4 waves (2009-2012). 49 states (Nebraska was omitted.). Human resource capacity1: size of human resource, Human resource capacity2: quality of human resource, Financial resource capacity: transportation revenue, General management capacity: policy experience on infrastructure management, Previous experience: policy experience on grant 
For control variables' impact on grant implementation pace, three variables representing state needs are reported as they are statistically significant in explaining dependent variables. Population density, the proxy of urbanization, has a negative effect, which indicates that more urbanized states will have correspondingly less success in implementing ARRA grants in a timely manner. The positive effect of economic condition is statistically significant in Model 2 and 3, which implies that higher unemployment rates induce state governments to implement ARRA grants quickly as a mechanism of stimulative economic policy. Finally, the median voter variable affects formula and total grants, which indicates that higher level of median income increases the pace of grant implementation. Additionally, according to the regression results, state politics are somewhat meaningful. Legislature control by Republicans is a variable that shows statistically strong evidence for explaining the dependent variable because the variable's p-value is less than $1 \%$ of the significance level in Models 2 and 3 . This implies that Republicans in the legislature are likely to support the rapid implementation of grants. However, divided government, meaning the governor's political party does not control at least one house in the legislature, has no significant effects. Republican governor also did not have statistically significant effects. Lastly, the other control variable, fiscal institution, shows negative effects on formula and total grants. This is consistent with intuition and prior literature in that stringent rules for financial management would hinder governments in the disbursement of funds. 


\subsubsection{Grant Impact on Government Expenditure}

This section presents the impact of ARRA grants on recipient government expenditures. I categorized ARRA grants, the independent variable, into discretionary and formula grants. Also, I classified expenditure, the dependent variable, into capital outlays, current operation expenditure, and total expenditure. Empirical tests in this section investigated if discretionary and formula grants affected state governments' three expenditures on transportation.

First, I determined how many states increased, in nominal terms, their transportation expenditure since the Great Recession. Table 30 shows that thirty-one states increased expenditure on transportation in FY 2009, compared to FY 2008. In FY 2010 and FY 2011, thirty-three and twenty-six states, respectively, expanded their spending. Specifically, when examining the two categories of expenditure (capital outlays and current operation), states tended to increase funds for capital outlays, rather than for current operation since FY 2008. In FY 2009, the number of states that increased funds on capital outlays was thirty-one, however only twenty-six states expanded their spending on current operation. Moreover, the statistics show the number of states that spent more money on transportation, whichever the expenditure is of total, capital or current operation, slightly declined from FY 2009 to FY 2011. This implies that states on the whole did not implement expansionary fiscal policies on transportation, because the shock of the Great Recession affected states even after the end of the recession. 
Table 30 Number of states that expand spending

\begin{tabular}{llll}
\hline Variable & 2009 & 2010 & 2011 \\
\hline Recovery in transportation total expenditure & 31 & 33 & 26 \\
Recovery in transportation capital outlays & 31 & 31 & 26 \\
Recovery in transportation current operation & 26 & 24 & 21 \\
\hline
\end{tabular}

I now present descriptive statistics of variables that were used in the regression models. First, state government expenditures, which are adjusted to real values in 2012 dollars and standardized by the number of residents, were organized into six types. Recovery amount in transportation of total expenditure, measured by the difference of transportation expenditure in each fiscal year and FY 2008, has a mean value of \$17.59 during the post-recession period (2009-2011).The mean value of recovery in capital outlays - measured by the same method used for total transportation expenditure recovery-was $\$ 16.49$. However, the amount of recovery in current operation expenditure after the recession in 2008 was $-\$ 1.83$ as the mean during the three years. For the evidence of the mean values of three recovery variables in Table 31 and the tendency of spending expansion in Table 30, the study interprets them as states were not sufficiently recovered for the three years of the post-recession.

Third, the mean of total transportation expenditure was $\$ 498.46$ for the three years spanning FY 2009-2011; the mean of capital outlays for transportation was \$289.98, and the mean of current operation expenditure was \$147.79. Approximately 58\% of transportation expenditure was used for capital outlays. 
Table 31 Descriptive statistics on Grant Impact

\begin{tabular}{|c|c|c|c|c|}
\hline Variable & Mean & $\begin{array}{l}\text { Std. } \\
\text { Dev. }\end{array}$ & Min & Max \\
\hline $\begin{array}{l}\text { Recovery in transportation total } \\
\text { expenditure }\end{array}$ & 17.590 & 72.803 & -165.45 & 322.105 \\
\hline $\begin{array}{l}\text { Recovery in transportation capital } \\
\text { outlays }\end{array}$ & 16.493 & 63.846 & -163.14 & 217.964 \\
\hline $\begin{array}{l}\text { Recovery in transportation current } \\
\text { operation }\end{array}$ & -1.833 & 23.494 & -118.60 & 58.402 \\
\hline Total transportation expenditure & 498.455 & 290.811 & 195.673 & 2210.536 \\
\hline Transportation Capital outlays & 289.983 & 172.954 & 84.903 & 1222.667 \\
\hline $\begin{array}{l}\text { Transportation current operation } \\
\text { expenditure }\end{array}$ & 147.787 & 140.479 & 46.522 & 1022.134 \\
\hline ARRA discretionary grants outlays & 9.286 & 14.931 & 0 & 114.255 \\
\hline ARRA formula grants outlays & 84.490 & 60.422 & 4.225 & 297.483 \\
\hline $\begin{array}{l}\text { Human resource capacity1: size of } \\
\text { human resource }\end{array}$ & 1.202 & 0.767 & 0.237 & 4.371 \\
\hline $\begin{array}{l}\text { Human resource capacity2: quality of } \\
\text { human resource }\end{array}$ & 8.36 & 1.27 & 5.86 & 12.40 \\
\hline $\begin{array}{l}\text { Financial resource capacity: } \\
\text { transportation revenue }\end{array}$ & 0.262 & 0.070 & 0.157 & 0.464 \\
\hline $\begin{array}{l}\text { General management capacity: policy } \\
\text { experience for infrastructure } \\
\text { management }\end{array}$ & 7.9 & 1.853 & 4 & 12 \\
\hline Urbanization & 1.932 & 2.567 & 0.012 & 11.869 \\
\hline Median voters & 50.117 & 7.604 & 35.078 & 66.6332 \\
\hline Economic condition & 7.481 & 2.371 & 3 & 13.8 \\
\hline Governor’s propensity (Republican) & 0.447 & 0.499 & 0 & 1 \\
\hline Divided government & 0.486 & 0.502 & 0 & 1 \\
\hline Republican legislature & 0.286 & 0.453 & 0 & 1 \\
\hline TELs & 8.34 & 7.889 & 0 & 25 \\
\hline BBRs & 2.44 & 0.806 & 0 & 3 \\
\hline Legislature Control & 0.000 & 0.294 & -1.032 & 0.483 \\
\hline
\end{tabular}

Note. The number of observations for all variables is 150 . The statistics of all explanatory variables represent one-year lagged values, except time-invariant variables (general management capacity, TEL, and legislature control) 
Fourth, following the explanatory variables that were presented in the first and the second research questions and results, Table 31 presents fiscal institutions, legislature control of bureaucracy, and the received ARRA grants. Stringency of TELs has a score of 8.34 out of 25 as its mean value, which implies that states do not have particularly strict rules on TELs. The mean of per capita ARRA discretionary grants for transportation was $\$ 9.29$ and its standard deviation was $\$ 14.93$, which indicates substantial variation across recipients. The ARRA formula grants' mean was $\$ 84.49$, which is nearly nine times greater than that of discretionary grants.

Turning to the results of the regression models, I present two different perspectives. One concerns which factors affect expenditure recovery (Table 32), and the other concerns general determinants analysis (Table 33), focusing on the three years of post-recession. The effects of the explanatory variables were estimated using linear regression with the Panel Corrected Standard Error (PCSE) estimator. Models 1-6 have heteroscedasticity ${ }^{44}$ problems and Models 1-2 have additional issues of autocorrelation ${ }^{45}$. To manage these problems, I used the PCSE technique, assuming panel-level heteroskedastic errors and panel-specific AR1 autocorrelation structure.

\footnotetext{
${ }^{44}$ Breusch-Pagan / Cook-Weisberg tests for checking the challenge of heteroskedasticity indicate all models have heteroscedasticity.

45 To check autocorrelation, Wooldridge test is conducted. Its null hypothesis is that there is no firstorder autocorrelation. The test for Model 1 shows $F(1,48)=5.191$ and $P r o b>F=0.027$, and for Model 2 shows $F(1,48)=10.363$ and Prob $>F=0.0023$. The test results mean that the null hypothesis is rejected and there is autocorrelation.
} 
Table 32 Predicting the Effect of GC and Grants on Expenditure Recovery

\begin{tabular}{|c|c|c|c|c|c|c|}
\hline \multirow[t]{2}{*}{ Recovery } & \multicolumn{2}{|c|}{ Total (Model1) } & \multicolumn{2}{|c|}{$\begin{array}{l}\text { Capital Outlays } \\
\text { (Model 2) }\end{array}$} & \multicolumn{2}{|c|}{$\begin{array}{l}\text { Current } \\
\text { expenditure } \\
\text { (Model 3) }\end{array}$} \\
\hline & Coef. & S.E & Coef. & S.E & Coef. & S.E \\
\hline $\begin{array}{l}\text { ARRA discretionary } \\
\text { grant outlays }\end{array}$ & $1.108^{*}$ & 0.651 & $1.298^{* *}$ & 0.639 & 0.189 & 0.316 \\
\hline $\begin{array}{l}\text { ARRA formula grant } \\
\text { outlays }\end{array}$ & -0.201 & 0.133 & 0.030 & 0.121 & -0.138 & 0.090 \\
\hline HR capacity1 & $-27.4 * * *$ & 9.904 & $-18.80 * *$ & 8.466 & -3.884 & 4.556 \\
\hline HR capacity2 & 6.271 & 4.151 & $6.549 *$ & 3.378 & $3.774^{* *}$ & 1.482 \\
\hline $\begin{array}{l}\text { Financial resource } \\
\text { capacity }\end{array}$ & $546.46^{* * *}$ & 108.07 & $346.8 * * *$ & 101.83 & $110.74 * * *$ & 35.50 \\
\hline $\begin{array}{l}\text { General management } \\
\text { capacity }\end{array}$ & -1.826 & 3.322 & 1.439 & 3.632 & $-2.199 * *$ & 0.854 \\
\hline Urbanization & $-8.92 * * *$ & 3.296 & $-6.861 * *$ & 2.728 & $-2.294 * *$ & 1.016 \\
\hline Economic Condition & -2.824 & 1.748 & -2.301 & 1.536 & -0.939 & 0.718 \\
\hline Median voter & $-2.01 * * *$ & 0.755 & -0.857 & 0.631 & -0.508 & 0.317 \\
\hline $\begin{array}{l}\text { Governor's } \\
\text { propensity(Republica } \\
\text { n) }\end{array}$ & $21.240 * *$ & 9.775 & 7.334 & 10.330 & $14.32^{* * *}$ & 4.745 \\
\hline Divided government & 10.258 & 11.173 & 1.982 & 9.547 & 0.157 & 4.450 \\
\hline $\begin{array}{l}\text { Republican } \\
\text { legislature }\end{array}$ & 18.304 & 12.533 & $27.637 * *$ & 11.653 & -5.109 & 6.001 \\
\hline TELs & $-1.291^{*}$ & 0.736 & $-1.481 * *$ & 0.699 & 0.052 & 0.241 \\
\hline BBRs & -4.064 & 6.118 & -0.339 & 6.522 & -0.012 & 2.231 \\
\hline Legislature Control & 0.739 & 21.363 & 17.172 & 20.082 & -4.079 & 6.420 \\
\hline Constant & 10.470 & 63.017 & -47.968 & 55.790 & -4.207 & 28.43 \\
\hline $\begin{array}{l}\text { Number of } \\
\text { Observations } \\
\text { Number of groups } \\
\mathrm{R}^{2} \\
\text { Prob> chi2 }\end{array}$ & $\begin{array}{l}147 \\
49 \\
0.7275 \\
0.000 \\
\end{array}$ & & $\begin{array}{l}147 \\
49 \\
0.4430 \\
0.000\end{array}$ & & $\begin{array}{l}147 \\
49 \\
0.2995 \\
0.000\end{array}$ & \\
\hline
\end{tabular}

Note. ${ }^{* * *} \mathrm{p}<0.01,{ }^{* *} \mathrm{p}<0.05, * \mathrm{p}<0.1$. S.E indicates heteroskedastic corrected standard error. Time period: 3 waves (2009-2011). 49 states (Nebraska was omitted.). HR capacity1: size of human resource, HR capacity2: quality of human resource, Financial resource capacity: transportation revenue, General management capacity: policy experience on infrastructure management 
Expenditure recovery is depicted in Table 32. Models 1-3 explain the recovery as a function of ARRA grants outlay, GC, state needs, state politics, and fiscal institutions. The first point of interpretation is the effect of grant. Discretionary grants did affect expenditure recovery for the three years (2009-2011), whereas formula grants were not statistically significant in expenditure recovery. One possible explanation can be adduced to interpret the result. Although the amount of discretionary grants is much smaller than formula grants, the achievement of competitive grants implies recipients' positive willingness to spend the grant, which played an important role in the recovery. In addition to the effectiveness of discretionary grants, one interesting point is that ARRA competitive grants affected only capital outlays and total expenditure. According to Census statistics, capital outlays indicate construction, replacement, addition, and other improvement. Expenditure for repairs is classified as a current operation expenditure. Thus, we can explain that ARRA competitive grants induced states to spend more funds on capital investments.

Second, GC components have substantial effects on the recovery. Surprisingly, human resource capacity 1 negatively affected the recovery. When holding other variable constant, additional increase in the size of human resource decreases the total expenditure recovery (per capita) by $\$ 27.42$. Meanwhile, financial resource capacity had positive effects on all kinds of expenditures recovery. That is, the more own-source revenue for transportation a state has, the greater recovery it achieves. 
Table 33 Predicting the Effect of Government Capacity and Grants on Expenditure

\begin{tabular}{|c|c|c|c|c|c|c|}
\hline \multirow[t]{2}{*}{ Expenditure } & \multicolumn{2}{|c|}{ Total (Model 4) } & \multicolumn{2}{|c|}{$\begin{array}{l}\text { Capital Outlays } \\
\text { (Model 5) }\end{array}$} & \multicolumn{2}{|l|}{$\begin{array}{l}\text { Current } \\
\text { expenditure } \\
\text { (Model 6) }\end{array}$} \\
\hline & Coef. & S.E & Coef. & S.E & Coef. & S.E \\
\hline $\begin{array}{l}\text { ARRA discretionary } \\
\text { grant outlays }\end{array}$ & $5.861^{* *}$ & 2.692 & $3.010^{*}$ & 1.695 & $3.483^{* *}$ & 1.559 \\
\hline $\begin{array}{l}\text { ARRA formula } \\
\text { grant outlays }\end{array}$ & 0.304 & 0.576 & 0.397 & 0.374 & -0.285 & 0.298 \\
\hline HR capacity1 & $226.23 * * *$ & 34.770 & $132.39 * * *$ & 19.261 & $119.03^{* * *}$ & 18.224 \\
\hline HR capacity2 & 20.490 & 13.245 & 10.459 & 8.725 & 3.100 & 6.038 \\
\hline $\begin{array}{l}\text { Financial resource } \\
\text { capacity }\end{array}$ & $774.42 * * *$ & 244.953 & $438.77 * *$ & 182.88 & 134.225 & 110.31 \\
\hline $\begin{array}{l}\text { General } \\
\text { management } \\
\text { capacity }\end{array}$ & 0.014 & 7.073 & 4.282 & 4.297 & $-8.488 * *$ & 3.910 \\
\hline Urbanization & $-37.19 * * *$ & 6.419 & $-14.83^{* * *}$ & 3.905 & $-13.53^{* * *}$ & 3.634 \\
\hline Economic Condition & -2.517 & 5.145 & $-6.987^{*}$ & 3.763 & $4.344^{*}$ & 2.506 \\
\hline Median voter & $7.234 * * *$ & 2.131 & 0.809 & 1.353 & $5.089 * * *$ & 1.127 \\
\hline $\begin{array}{l}\text { Governor's } \\
\text { propensity }\end{array}$ & $56.941 * *$ & 22.722 & 23.705 & 18.085 & $27.065^{* *}$ & 11.651 \\
\hline Divided government & $54.709 * *$ & 22.334 & 12.400 & 17.592 & $30.389 * * *$ & 10.739 \\
\hline $\begin{array}{l}\text { Republican } \\
\text { legislature }\end{array}$ & $47.493^{*}$ & 26.772 & $38.376^{*}$ & 19.713 & 6.030 & 11.851 \\
\hline TELS & 1.525 & 1.542 & $2.039 *$ & 1.205 & 0.487 & 0.830 \\
\hline BBRs & $33.681 * *$ & 14.845 & $24.487 * *$ & 11.113 & 3.379 & 8.242 \\
\hline Legislature Control & -57.385 & 37.982 & -37.381 & 30.212 & -3.712 & 19.798 \\
\hline Constant & $-615.56^{* * *}$ & 192.073 & -198.480 & 129.86 & $-294.6^{* * *}$ & 92.002 \\
\hline $\begin{array}{l}\text { Number of } \\
\text { Observations } \\
\text { Number of groups } \\
\mathrm{R}^{2} \\
\text { Prob> chi2 }\end{array}$ & $\begin{array}{l}147 \\
49 \\
0.8419 \\
0.000 \\
\end{array}$ & & $\begin{array}{l}147 \\
49 \\
0.7696 \\
0.000 \\
\end{array}$ & & $\begin{array}{l}147 \\
49 \\
0.8462 \\
0.000 \\
\end{array}$ & \\
\hline
\end{tabular}

Note. ${ }^{* * *} \mathrm{p}<0.01,{ }^{* *} \mathrm{p}<0.05,{ }^{*} \mathrm{p}<0.1$. S.E indicates heteroskedastic corrected standard error. Time period: 3 waves (2009-2011). 49 states (Nebraska was omitted.). HR capacity1: size of human resource, HR capacity2: quality of human resource, Financial resource capacity: transportation revenue, General management capacity: policy experience on infrastructure management 
Compared to the recovery, determinants of expenditure during the three postrecession years present different results (Table 33). First, discretionary ARRA grants were statistically significant. Second, human resource capacity 1 is also differently reported as it had positive effects on expenditure, compared to negative effects on recovery. Third, fiscal institutions, TELs and BBRs, were statistically significant on expenditure. They positively affected expenditure, which indicates that stringent fiscal institutions paradoxically help to increase government spending. Lastly, divided states were likely to increase expenditure compared to unitary states, according to Models 4 and 6. 


\section{Chapter VI. CONCLUSION}

\subsection{Summary and discussion}

This dissertation aimed to determine the significance of government capacity (GC), specifically as a factor in easing the impacts of the recent economic crisis. Taking ARRA grants as the research case, this dissertation began with a literature review (Chapter II) of the three stages of an ARRA grant: grant competition, implementation, and impact. The review revealed gaps in literature pertaining to the lack of theoretical background for the link between GC and performance and for the concept and measurement of GC. Chapter III proposed theoretical backgrounds for the link and the concept. Based on Systems Theory and Resource Based Theory (RBT), I then established the theoretical framework. Referring to previous literature, for the present study, I defined the concept of GC as the ability of a government to outperform others in the acquisition of grant, the implementation of grant, and the recovery of expenditure. To measure GC in this study, we use its components: human resource as human resource capacity 1 (the size of human resource), human resource capacity 2 (the quality of human resource); financial resource as financial resource capacity; and intellectual ability as general management capacity (infrastructure management) and previous experience (grant experience). Then, Chapters IV and V presented empirical models and results. The following sections provide the test results and discussions. 


\subsubsection{Grant acquisition}

The first empirical model examines factors that affect ARRA grant competition. Utilizing the case of federal transportation grants under the Recovery Act, the study established a model of discretionary grants with independent variables-human resource capacity, financial resource, and intangible resource capacity. The model covers political variables following the political science literature and other environmental variables.

From the evidence of the quantitative analysis (Table 34), two government capacity components_-human resource capacity 2 and previous experience-positively affect grant acquisition. Another component of capacity, human resource capacity 1, has a negative effect. The results partially support the government capacity hypothesis in which higher capacity is helpful for acquiring competitive grants.

There is another perspective on explaining the conflicting results between HR capacity 1 and 2. This is consistent with the implication of cutback management or turnaround management. Ukeles (1982) stressed efficient and effective management under constraints of resources, based on his experience in New York City that reduced the administrative body but achieved the successful rescue in the crisis. It implies "working smarter” or "doing more with less” is more important than the size of resources. According to the implication, the negative effect of HR capacity 1 and the positive effect of HR capacity 2 are natural results, implying that HR quality is more important in the crisis than HR size.

Financial resource capacity did not have significant effects on the grant acquisition, and the direction of effects was negative. The result may be due to "decreased demand for 
external funding” (Hall, 2008a, p. 14), which means affluent states with sufficient financial resources are likely to be passive about federal grant applications. Or the result may be attributable to a redistributive function of ARRA grants that supports economically disadvantaged regions (Gimpel et al., 2012; Young \& Sobel, 2013).

Positive effects of policy experience are in line with prior literature (e.g., Rich, 1989). Abilities in professional grant writing and appropriate planning are cultivated by relevant experience on grant applications. Thus it is natural that the result indicates previous experience variable had positively and statistically significant effects on the grant acquisition.

Table 34 Summary of tests for grant acquisition

\begin{tabular}{|c|c|c|}
\hline & $\begin{array}{l}\text { sign of } \\
\text { effect }\end{array}$ & $\begin{array}{l}\text { Standardized } \\
\text { Beta Coef. }\end{array}$ \\
\hline $\begin{array}{l}\text { Human resource capacity1: size of human resource } \\
\text { Human resource capacity2: quality of human resource } \\
\text { Financial resource capacity: transportation expenditure } \\
\text { General management capacity: policy experience for } \\
\text { infrastructure management }\end{array}$ & $\begin{array}{l}- \\
+\end{array}$ & $\begin{array}{l}-0.345 \\
0.423\end{array}$ \\
\hline Previous experience: policy experience for grant & + & 0.336 \\
\hline $\begin{array}{l}\text { House Appropriations Committee } \\
\text { House Transportation Committee } \\
\text { Urbanization } \\
\text { Economic condition } \\
\text { Median voters }\end{array}$ & + & 0.369 \\
\hline
\end{tabular}

As a control variable, the number of House Transportation Committee members from each state is reported as having a positive effect on grant acquisition, which means the Pork Barrel hypothesis is still valid. However, the other political variable, House Appropriations Committee, is not significant; so the hypothesis is also partially supported. 
The more interesting result between the government capacity variables and the political variables concerns the Standardized Beta Coefficients. According to the results, the Beta Coefficient of HR capacity 2 is greater than that of the House Transportation Committee variable. These results do not mean only GC matter or politics is not important. As Hall (2008a) said, the results imply government capacity is a more important factor in the grant competition situation or, at least, it is not less important than the political factor.

\subsubsection{Grant Implementation}

I conducted analyses to investigate whether or not government capacity affects ARRA grant fund implementation in order to answer the second research question. Speedy implementation of ARRA funds by recipient governments is an indicator of performance (to evaluate success), because the Recovery Act aimed to stimulate the economy and to recover subnational governments' spending.

For the models of the second research question, I inputted government capacity variables-human resource capacity, financial resource capacity, and intangible resource capacity - and control variables to explain the variation of ARRA fund implementation. To compare types of grant, I separately regressed discretionary grants, formula grants, and total grants.

As seen in Table 35, data and results of the quantitative analyses indicate that human resource capacity and financial resource capacity have statistically significant effects on the dependent variables. Moreover, intangible resource capacity (previous 
experience), measured by the amount of previous funds, is shown to facilitate speedy implementation during the four years since the ARRA subsidies. Those results are consistent with prior literature (Carley et al., 2015; Terman and Feiock, 2014). Carley et al. (2015) also found evidence on the positive effects of relevant experience and financial management capacity on energy grant implementation. Terman and Feiock (2014) revealed a negative association between lack of staff capacity and implementation delay.

Table 35 Summary of tests for grant implementation

\begin{tabular}{l|c|c|c}
\hline Implementation & $\begin{array}{c}\text { Competitive } \\
\text { (Model 1) }\end{array}$ & $\begin{array}{c}\text { Formula } \\
\text { (Model 2) }\end{array}$ & $\begin{array}{c}\text { Total } \\
\text { (Model 3) }\end{array}$ \\
\hline Human resource capacity1 & & & + \\
Human resource capacity2 & & + & + \\
Financial resource capacity & & + & + \\
General management capacity & & - & - \\
Previous experience & & + & + \\
\hline Urbanization & & + & + \\
Economic Condition & & + & + \\
Median voter & & - & - \\
\hline Republican Governor & & - & - \\
Divided government & & & + \\
Republican legislature & & & + \\
BBRs & & & \\
TELs & & & \\
\hline
\end{tabular}

Additionally, states that were less urbanized, faced higher unemployment rates, and had higher median income are likely to spend the ARRA funds faster than others. This 
implies that these states outperformed—in terms of speedy implementation—other states that were more urbanized, experienced lower unemployment, and had lower median income level. Moreover, states with Republican legislature control were more likely to spend ARRA funds faster than others with Democratic control of legislature. This is a somewhat different result from the thought that democratic states might have "higher goal alignments” with the Democratic president’s policy (e.g., Carley et al., 2015; Jennings et al 2012). Lastly, my data found that more stringent fiscal institutions (TELs and BBRs) impeded fast implementation, which is consistent with prior literature (Hou \& Smith, 2010; Mahdavi \& Westerlund, 2011; Maher \& Deller, 2012). From the results of fiscal institutions, this dissertation does not want to assert that TELs and BBRs are unnecessary rules for the efficient policy implementation. Rather, the negative statistical association indicates that the institutions fulfill the roles given to themselves even in the crisis.

\subsubsection{Grant Impact and Government Expenditure}

The third research question concerned the impact of ARRA grants on recipient government expenditures. According to the data, had the federal government failed to provide fiscal assistance, states would have encountered severe deficits and would have been forced to cut expenditures on most public services. If so, the intellectual curiosity would be about how much the federal ARRA grants affected states' recovery of expenditure. Thus, this study examined the impact of ARRA grants on the recovery (2009-2011) and on expenditures (2009-2011), in which the recovery and expenditures were categorized into total, capital and current operation. 
In terms of dependent variables, the study set recovery variables as the amount of change in transportation expenditure (total, capital, and current) between each year and FY 2008, and expenditure as each year's transportation expenditure. Key independent variables are ARRA discretionary grants and ARRA formula grants. I classified these variables to test effects of the two grants allocated by different method and process. In addition, I investigated whether or not government capacity had effects on the recovery and expenditures.

According to the test results (Table 36), between the two ARRA grant-types only discretionary grants had statistically significant on and positively affected expenditure recovery and transportation investment. This implies that despite having relatively smaller dollar-amounts of subsidy, the acquired competitive grant was more effective than the distributed formula grant as a stimulus to increase spending. These results may come from the nature of different types of grants. Formula grants are allocated by the pre-existing criteria that recipients anticipate how much they can receive. So, formula grants are likely to be used in current operation and ongoing projects. In contrast, subnational government must prepare a project by a well-designed plan in order to apply for a competitive grant. So, competitive grants are likely to induce recipients to spend funds on capital outlays and new projects. In addition, the result indicates that ARRA grants increased transportation expenditures. This result rebuts Knight (2002) that insisted crowding-out effects of the federal highway grants.

Turning to GC components, the regression results show their coefficients are significant on both transportation expenditure recovery and investment. Financial resource 
capacity's positive effects were consistently significant on recovery and expenditures. Because financial resource indicates transportation revenue, states with a higher level of resources can increase transportation expenditures more than ones with a lower level of resources. Human resource (HR) capacities showed contradictory results. HR capacity 2 had statistically and positively significant effects only on expenditure recovery. HR capacity 1 had negative effects on recovery, but positive effects on expenditure. Expenditure recovery and transportation investment are all significant purposes of ARRA. However, in the crisis situation, the more important thing or the higher priority was to recover subnational governments' expenditure level at least on the same plane as the prerecession level. In this perspective, the regression results imply that the quality of $\mathrm{HR}$, rather than HR size, was more helpful for overcoming the recession.

For other control variables, similar to the test results of implementation, less urbanized states were likely to do well in recovery and spend more. It implies that presumably, more urbanized states had more difficulty than less urbanized ones in implementing grants and recovering expenditure due to more complicated conditions. Regarding political propensity, Republican states tended to have advantages in the recovery and the expansion of expenditure-according to the coefficients of political variables. In addition, the variable, BBRs, was reported as leverages to increase transportation expenditures. This result seemingly contradicts prior studies. However, possible answers can be made, when focusing on the different dependent variable and the analysis case. Previous literature (e.g., Alt \& Lowry, 1994; Hou \& Smith, 2010; Mahdavi \& Westerlund, 2011; Poterba, 1994) revealed BBRs were positively associated with 'fund balance.' The analytic model dealt with 2009-2011 when federal grants influx sharply increased and 
states continued to increase expenditure. Or maybe states with the fiscal institutions (i.e. BBRs and TELs) learn to manage their finances better with less. Thus, it is possible that the regression result of BBR is not wholly contrary to the prior literature.

Table 36 Summary of tests for grant impact

\begin{tabular}{|c|c|c|c|c|c|c|}
\hline & \multicolumn{3}{|c|}{$\begin{array}{l}\text { Expenditure Recovery } \\
\text { (Model 1-3) }\end{array}$} & \multicolumn{3}{|c|}{$\begin{array}{l}\text { Transportation Investment } \\
\text { (Model 4-6) }\end{array}$} \\
\hline & Total & Capital & Current & Total & Capital & Current \\
\hline $\begin{array}{l}\text { ARRA discretionary grant } \\
\text { ARRA formula grant }\end{array}$ & + & + & & + & + & + \\
\hline $\begin{array}{l}\text { Human resource capacity1 } \\
\text { Human resource capacity2 }\end{array}$ & - & $\begin{array}{l}- \\
+\end{array}$ & + & + & + & + \\
\hline $\begin{array}{l}\text { Financial resource capacity } \\
\text { General management capacity }\end{array}$ & + & + & $\begin{array}{l}+ \\
-\end{array}$ & + & + & \\
\hline $\begin{array}{l}\text { Urbanization } \\
\text { Economic Condition } \\
\text { Median voter }\end{array}$ & - & - & - & $\begin{array}{l}- \\
+\end{array}$ & - & $\begin{array}{l}- \\
+ \\
+\end{array}$ \\
\hline $\begin{array}{l}\text { Governor's propensity } \\
\text { (Republican) } \\
\text { Divided government } \\
\text { Republican legislature }\end{array}$ & + & + & + & $\begin{array}{l}+ \\
+ \\
+\end{array}$ & + & $\begin{array}{l}+ \\
+\end{array}$ \\
\hline $\begin{array}{l}\text { TELs } \\
\text { BBRs } \\
\text { Legislature Control }\end{array}$ & - & - & & + & $\begin{array}{l}+ \\
+\end{array}$ & \\
\hline
\end{tabular}




\subsection{Conclusion}

This dissertation began with questions about government capacity and its role in the critical situation experienced by all states globally: the significant economic shock of the Great Recession. Through the quantitative multivariate analyses, I found strong evidence of the impact of government capacity.

Overall, government capacity of states played a significant role in the conjuncture of ARRA situation. For states with higher government capacity, strengths, weaknesses, opportunities, and threats (SWOT) analysis was used to explain how their strength (S) of capacity turned the threat $(\mathrm{T})$ of the Great Recession to their advantage for opportunity $(\mathrm{O})$ for restoration and development—compensating for weakness (W). However, according to types of capacity and to phases of the ARRA funds (acquisition, implementation, and impact), the effects of capacity were shown to be somewhat different.

Specifically, the size of human resource (human resource capacity 1) was not helpful for acquiring ARRA grants, but was meaningful for ARRA implementation and the expansion of expenditures. The quality of human resource (human resource capacity 2) played an important role in grant acquisition and recovery, but was not significant in implementation. Financial resource capacity was not significantly different from zero in grant competition, but consistently positively significant in ARRA grant implementation and recovery and the increase of expenditure. As an intangible resource, infrastructure management experience (general management capacity) was mostly insignificant for all ARRA phases-except the negative effects on recovery and expenditure in current 
operation. Grant experience (previous experience) was positively significant on grant acquisition and implementation for formula and total grants.

\subsubsection{Policy implication}

From the empirical test results described above, I found some policy implications. First, the empirical findings show that internal system factors (i.e., GC components) had statistically significant impacts. Based on the results and Systems Theory, the present study recommends that subnational governments concentrate on what they do by themselves at first rather than what they cannot deal with. For example, governments can control or develop their capacity, but it is too difficult to influence other external factors, such as federal actions including federal politics and federal bureaucrats. This study does not intend to imply that only GC is important or that GC is significantly more critical than other factors; however, the study does argue that subnational governments benefit from prior focus on their internal system because they have direct control of this system and thus, they can effectively manage and refine it in a relatively short time period.

Second, in terms of effects of human resources (HR), the findings indicate the quality of HR — measured by the relative level of compensation—played a significant role in the acquisition of ARRA grants and expenditure recovery, whereas the size of HR did not. This indicates that the quality of HR is more important than the size in coping with crisis. For enhancing government capacity, especially HR capacity, governments may aim to increase the number of employees or increase the quality of employees. The empirical results imply that it is better to focus on quality rather than size. Of course, the relatively 
higher level of compensation may attribute to the higher educated employees or generous treatment with higher level of salary. In any case, governments would benefit in that higher educated employees would be likely to produce better outputs and generous treatment would likely increase employee morale and induce employees to succeed at their jobs.

Third, the empirical test reveals that another GC component, financial resource, was also important factor-particularly in expenditure recovery. Understandably, larger financial resource should be a significant capacity for government to disburse funds at a suitable time and place. Thus, governments must skillfully manage the system for securing transportation related revenue even in times of calm.

Lastly, the findings present interesting evidence in terms of the impact of ARRA grants. Although the dollar-amounts of competitive grants are much smaller than that of formula grants, only competitive grants had statistically and positively significant effects on expenditure recovery and expenditure. This implies that subnational governments must focus more on grant competition. Even though significantly more commitments are needed to plan and apply for competitive grants, competitive transportation grants may be more useful for governments to recover expenditure level and to invest in transportation.

\subsubsection{Contributions}

I present three kinds of contributions. This dissertation contributes to the academic discussion of management by developing a theoretical framework to explain the link between GC and its performance, based on Systems Theory and Resource Based Theory 
(RBT). It would be valuable for the current discussion in the research literature on how to account for the relation, in terms of theoretical background.

Another contribution, pertaining to government capacity, is that the present study provides a conceptualization for the meaning of government capacity - to classify its components and to operationalize the components with multiple proxies using the two theories. The present study improves on prior empirical studies that generally did not provide specific theory or that only used a simple proxy for government capacity (e.g., the number of public servants).

In terms of the target of analysis, a third contribution of this dissertation is that it is the first study to investigate the three stages of ARRA transportation grants. The study revealed that GC played an important role in ARRA grant acquisition, implementation, and impact. In addition, regarding intergovernmental grants issues, few studies of public finance have examined the acquisition and implementation of federal grants. Thus, this dissertation, as a start-up study on this topic, provides initial understanding of the relation between GC and intergovernmental grants.

\subsubsection{Limitations}

Policy implication and the contributions notwithstanding, like other empirical studies, the present study has some weaknesses. First, this study proposes a theoretical framework by using two background theories: Systems Theory and RBT. Though the

dissertation assumes that the theories can be applied to state government organizations and utilized lessons of theories, the theories might not be perfectly appropriate for public 
organizations-because they were generated in the field of business administration and reflect the nature of private organizations.

Second, the operationalization of variables may not perfectly capture the nature of each variable. This study suggests a theoretical framework for the concept and measurement of GC, but it might not represent all aspects of GC. For example, I measured the quality of HR using the relative level of compensation for DOT employees. However, aside from compensation, there could be other proxies for the quality of HR, such as level of education, length of service of employees, degree of job-training, etc.

Third, this study includes a small number of observations in the quantitative analyses, because of the characteristic that ARRA funds are distributed as a one-time-fund. Especially for the analysis of the first question — the acquisition of ARRA grant - the total number of observations is 50. Even though this number represents the population (50 states) under ARRA, this empirical result can be used to explain only the recent recession (December 2007 - June 2009), and cannot be generalized to explain other situations.

Lastly, this dissertation could not sufficiently control the regional differences of states, such as project composition and climate. According to location and to other condition of states, the states have different management task complexity. The dissimilarity among states may affect the performance of states. Though the study employed urbanization, economic condition, and the level of income, I could not assert that these factors are adequate to control the differences. 


\subsubsection{Suggestions for Future Research}

This dissertation presents a theoretical framework and empirical test results. As described in the limitations above, however, I cannot assert that the study perfectly characterizes the relationship between GC and performance or that the proposed theoretical framework and measurement sufficiently capture the characteristics of variables. The study provides additional evidence for — and is only one step along the path to explaining — the role of GC.

Thus, several avenues of research remain available to future studies. First, scholars can expand the theoretical background beyond the two theories presented here, or develop a critical application of the theories for public organizations. Scholars may find additional or alternative theories for the link between GC and performance, or suggest a more analytic utilization of the theories for the public sector.

Second, qualitative studies may remedy the caveats about the operationalization of GC. As described above, the quality of HR is too difficult to be measured by using data released to the public. Future studies should use qualitative methods, such as interviews, surveys, or focus groups. This would benefit and develop the research literature on public management.

Lastly, the framework of this dissertation could be replicated at the local level. It is possible that grant issues are more significant for local governments than for states. Compared to states, higher variability in GC and performance among localities is expected. 


\section{REFERENCES}

ACIR. (1987). Fiscal discipline in the federal system: experience of the states. Washington, D.C.: Advisory Commission on Intergovernmental Relations.

Akin, J. S. (1973). Fiscal Capacity and the Estimation Method of the Advisory Commission on Intergovernmental Relations. National Tax Journal, 26(2), 275-291.

Alt, J. E., \& Lowry, R. C. (1994). Divided Government, Fiscal Institutions, and Budget Deficits: Evidence from the States. American Political Science Review, 88(04), 811-828. doi:doi:10.2307/2082709

Amiel, L., Deller, S., \& Stallmann, J. (2009) The Construction of a Tax and Expenditure Limitation Index for the US. Staff Paper Series: University of Wisconsin, Agricultural and Applied Economics.

Balla, S. J., Lawrence, E. D., Maltzman, F., \& Sigelman, L. (2002). Partisanship, Blame Avoidance, and the Distribution of Legislative Pork. American Journal of Political Science, 46(3), 515-525. doi:10.2307/3088396

Barney, J. (1991). Firm Resources and Sustained Competitive Advantage. Journal of Management, 17(1), 99-120. doi:10.1177/014920639101700108

Barney, J. B., \& Clark, D. N. (2007). Resource-based theory : creating and sustaining competitive advantage. Oxford ; New York: Oxford University Press.

Barney, J. B., Ketchen, D. J., \& Wright, M. (2011). The Future of Resource-Based Theory: Revitalization or Decline? Journal of Management, 37(5), 1299-1315. doi:10.1177/0149206310391805

Baum, C. F. (2006). An Introduction to Modern Econometrics Using Stata: StataCorp LP.

Berry, C. R., Burden, B. C., \& Howell, W. G. (2010). The President and the Distribution of Federal Spending. American Political Science Review, 104(04), 783-799. doi:doi:10.1017/S0003055410000377 
Berry, W. D., \& Fording, R. C. (1997). Measuring State Tax Capacity and Effort. Social Science Quarterly, 78(1), 158-166.

Borge, L.-E. (2008). Public sector efficiency: the roles of political and budgetary institutions, fiscal capacity, and democratic participation. Public Choice, 136(3-4), 475-495. doi:10.1007/s11127-008-9309-7

Bowman, A. O. M., \& Kearney, R. C. (1988). Dimensions of State Government Capability. The Western Political Quarterly, 41(2), 341-362. doi:10.2307/448542

Bryson, J. M., Ackermann, F., \& Eden, C. (2007). Putting the Resource-Based View of Strategy and Distinctive Competencies to Work in Public Organizations. Public Administration Review, 67(4), 702-717. doi:10.1111/j.1540-6210.2007.00754.x

Bureau of Transportation Statistics. (2014). Government Transportation Financial Statistics 2014. $\quad$ Retrieved from http://www.rita.dot.gov/bts/sites/rita.dot.gov.bts/files/publications/government_tra nsportation_financial_statistics/2014/index.html

Carley, S., Nicholson-Crotty, S., \& Fisher, E. J. (2015). Capacity, Guidance, and the Implementation of the American Recovery and Reinvestment Act. Public Administration Review, 75(1), 113-125. doi:10.1111/puar.12294

Chodorow-Reich, G., Feiveson, L., Liscow, Z., \& Woolston, W. G. (2012). Does State Fiscal Relief During Recessions Increase Employment? Evidence from the American Recovery and Reinvestment Act. American Economic Journal: Economic Policy, 4(3), 118-145. doi:10.2307/23249923

Christensen, R. K., \& Gazley, B. (2008). Capacity for public administration: analysis of meaning and measurement. Public Administration and Development, 28(4), 265279. doi:10.1002/pad.500

Cogan, J. F., Cwik, T., Taylor, J. B., \& Wieland, V. (2010). New Keynesian versus old Keynesian government spending multipliers. Journal of Economic Dynamics and Control, 34(3), 281-295. doi:http://dx.doi.org/10.1016/j.jedc.2010.01.010

Collins, B. K., \& Gerber, B. J. (2006). Redistributive Policy and Devolution: Is State Administration a Road Block (Grant) to Equitable Access to Federal Funds? 
Journal of Public Administration Research and Theory, 16(4), 613-632. doi:10.1093/jopart/muj010

Collins, B. K., \& Gerber, B. J. (2008). Taken for Granted? Managing for Social Equity in Grant Programs. Public Administration Review, 68(6), 1128-1141. doi:10.1111/j.1540-6210.2008.00960.x

Compson, M. L. (2003). Historical Estimates of Total Taxable Resources for U.S. States, 1981-2000. Publius: The Journal of Federalism, 33(2), 55-72.

Congleton, R., \& Bennett, R. (1995). On the political economy of state highway expenditures: Some evidence of the relative performance of alternative public choice models. Public Choice, 84(1-2), 1-24. doi:10.1007/BF01047798

CONGRESSIONAL BUDGET OFFICE. (2011). Federal Grants to State and Local Governments. (4472). Washington, D.C.

Conley, T. G., \& Dupor, B. (2013). The American Recovery and Reinvestment Act: Solely a government jobs program? Journal of Monetary Economics, 60(5), 535-549. doi:http://dx.doi.org/10.1016/j.jmoneco.2013.04.011

Dawes, S. S., Cresswell, A. M., \& Pardo, T. A. (2009). From "Need to Know" to "Need to Share": Tangled Problems, Information Boundaries, and the Building of Public Sector Knowledge Networks. Public Administration Review, 69(3), 392-402. doi:10.1111/j.1540-6210.2009.01987_2.x

Deller, S., Stallmann, J. I., \& Amiel, L. (2012). The Impact of State and Local Tax and Expenditure Limitations on State Economic Growth. Growth and Change, 43(1), 56-84. doi:10.1111/j.1468-2257.2011.00577.x

Dincecco, M., \& Prado, M. (2012). Warfare, fiscal capacity, and performance. Journal of Economic Growth, 17(3), 171-203. doi:10.1007/s10887-012-9079-4

Donahue, A. K., Selden, S. C., \& Ingraham, P. W. (2000). Measuring Government Management Capacity: A Comparative Analysis of City Human Resources Management Systems. Journal of Public Administration Research and Theory, 10(2), 381-412. 
Evans, D. (1994). Policy and Pork: The Use of Pork Barrel Projects to Build Policy Coalitions in the House of Representatives. American Journal of Political Science, 38(4), 894-917. doi:10.2307/2111726

Fellegi, I. (1996). Strengthening our Policy Capacity: Report of the Deputy Ministers Task Force. Ottawa: Supply and Services Canada: ISBN 0-662-62083-4.

Fisher, R. C. (2007). State \& Local Public Finance. Mason, OH, USA: Thomson SouthWestern.

Fisher, R. C., \& Bristle, A. (2012). State Intergovernmental Grant Programs. In R. D. Ebel \& J. E. Petersen (Eds.), The Oxford Handbook of State and Local Government Finance (pp. 213-245). New York: Oxford University Press.

Fox, W. F. (1977). Fiscal capacity or resource capacity? Paper presented at the Proceedings of the Annual Conference on Taxation Held under the Auspices of the National Tax Association-Tax Institute of America.

Fredericksen, P., \& London, R. (2000). Disconnect in the Hollow State: The Pivotal Role of Organizational Capacity in Community-Based Development Organizations. Public Administration Review, 60(3), 230-239. doi:10.1111/0033-3352.00083

Gamkhar, S., \& Pickerill, J. M. (2012). The State of American Federalism 2011-2012: A Fend for Yourself and Activist Form of Bottom-Up Federalism. Publius: The Journal of Federalism, 42(3), 357-386. doi:10.1093/publius/pjs027

Gargan, J. J. (1981). Consideration of Local Government Capacity. Public Administration Review, 41(6), 649-658. doi:10.2307/975741

Gimpel, J. G., Lee, F. E., \& Thorpe, R. U. (2012). Geographic Distribution of the Federal Stimulus of 2009. Political Science Quarterly, 127(4), 567-595. doi:10.1002/j.1538-165X.2012.tb01128.x

Gordon, T. M. (2012). State and Local Fiscal Institutions in Recession and Recovery. In R. D. Ebel \& J. E. Petersen (Eds.), The Oxford Handbook of State and Local Government Finance (pp. 246-267). New York: Oxford University Press. 
Graddy, E. A., \& Chen, B. (2006). Influences on the Size and Scope of Networks for Social Service Delivery. Journal of Public Administration Research and Theory, 16(4), 533-552. doi:10.1093/jopart/muj005

Gramlich, E. M., \& Rubinfeld, D. L. (1982). Micro Estimates of Public Spending Demand Functions and Tests of the Tiebout and Median-Voter Hypotheses. Journal of Political Economy, 90(3), 536-560. doi:10.2307/1831369

Hall, J. L. (2008a). Assessing Local Capacity for Federal Grant-Getting. The American Review of Public Administration. doi:10.1177/0275074007311385

Hall, J. L. (2008b). The Forgotten Regional Organizations: Creating Capacity for Economic Development. Public Administration Review, 68(1), 110-125. doi:10.1111/j.1540-6210.2007.00841.x

Haughton, G. (1999). Environmental Justice and the Sustainable City. Journal of Planning Education and Research, 18(3), 233-243. doi:10.1177/0739456x9901800305

Hauk Jr, W. R., \& Wacziarg, R. (2007). Small States, Big Pork. Quarterly Journal of Political Science, 2(1), 95-106. doi:10.1561/100.00005048

Hillman, A. L. (2009). Public Finance and Public Policy: Responsibilities and Limitations of Government: Cambridge University Press.

Honadle, B. W. (1981). A Capacity-Building Framework: A Search for Concept and Purpose. Public Administration Review, 41(5), 575-580. doi:10.2307/976270

Hou, Y., \& Moynihan, D. P. (2008). The Case for Countercyclical Fiscal Capacity. Journal of Public Administration Research and Theory, 18(1), 139-159. doi:10.1093/jopart/mum006

Hou, Y., Moynihan, D. P., \& Ingraham, P. W. (2003). Capacity, Management, and Performance: Exploring the Links. The American Review of Public Administration, 33(3), 295-315. doi:10.1177/0275074003251651

Hou, Y., \& Smith, D. (2010). Do state balanced budget requirements matter? Testing two explanatory frameworks. Public Choice, 145(1-2), 57-79. doi:10.1007/s11127-0099528-6 
Hou, Y., \& Smith, D. L. (2006). A Framework for Understanding State Balanced Budget Requirement Systems: Reexamining Distinctive Features and an Operational Definition. Public Budgeting \& Finance, 26(3), 22-45. doi:10.1111/j.15405850.2006.00853.x

Howlett, M. (2009). Policy analytical capacity and evidence-based policy-making: Lessons from Canada. Canadian Public Administration, 52(2), 153-175. doi:10.1111/j.1754-7121.2009.00070_1.x

Ingraham, P. W., \& Donahue, A. K. (2000). Dissecting the black box revisited: Characterizing government management capacity. In C. J. Heinrich \& J. L.E. Lynn (Eds.), Governance and performance: New perspectives (pp. 292-318). Washington, DC: Georgetown University Press.

Jennings, E. T., Hall, J. L., \& Zhang, Z. (2012). The American Recovery and Reinvestment Act and State Accountability. Public Performance \& Management Review, 35(3), 527-549. doi:10.2753/PMR1530-9576350308

Johnson, N. (2009). Does the American Recovery and Reinvestment Act Meet Local Needs? State \& Local Government Review, 41(2), 123-127. doi:10.2307/25593638

Kettl, D. F. (2011). The Politics of the Administrative Process: CQ Press.

Kincaid, J. (1989). Fiscal Capacity and Tax Effort of the American States: Trends and Issues. Public Budgeting \& Finance, 9(3), 4-26. doi:10.1111/1540-5850.00825

Knight, B. (2002). Endogenous Federal Grants and Crowd-out of State Government Spending: Theory and Evidence from the Federal Highway Aid Program. The American Economic Review, 92(1), 71-92. doi:10.2307/3083322

Krause, R. M., Feiock, R. C., \& Hawkins, C. V. (2016). The Administrative Organization of Sustainability Within Local Government. Journal of Public Administration Research and Theory, 26(1), 113-127. doi:10.1093/jopart/muu032

Ladd, H. F. (1975). Local Education Expenditures, Fiscal Capacity, and the Composition of the Property Tax Base. National Tax Journal, 28(2), 145-158. 
Larcinese, V., Rizzo, L., \& Testa, C. (2013). Why Do Small States Receive More Federal Money? U.S. Senate Representation and the Allocation of Federal Budget. Economics \& Politics, 25(3), 257-282. doi:10.1111/ecpo.12012

Lauderdale, B. E. (2008). Pass the Pork: Measuring Legislator Shares in Congress. Political Analysis, 16(3), 235-249. doi:10.1093/pan/mpm038

Lazarus, J., \& Steigerwalt, A. M. Y. (2009). Different Houses: The Distribution of Earmarks in the U.S. House and Senate. Legislative Studies Quarterly, 34(3), 347373. doi:10.3162/036298009788897772

Lee, S.-Y., \& Whitford, A. B. (2012). Assessing the Effects of Organizational Resources on Public Agency Performance: Evidence from the US Federal Government. Journal of Public Administration Research and Theory. doi:10.1093/jopart/mus050

Levitt, S. D., \& Snyder, J. M., Jr. (1995). Political Parties and the Distribution of Federal Outlays. American Journal of Political Science, 39(4), 958-980. doi:10.2307/2111665

Lucke, R. B. (1984). State Tax Capacity and the Representative Tax System. Journal of Education Finance, 9(3), 332-357.

Mahdavi, S., \& Westerlund, J. (2011). Fiscal stringency and fiscal sustainability: Panel evidence from the American state and local governments. Journal of Policy Modeling, 33(6), 953-969. doi:http://dx.doi.org/10.1016/j.jpolmod.2011.08.015

Maher, C. S., \& Deller, S. C. (2012). Measuring the Impacts of TELs on Municipal Financial Conditions. In H. Levine, E. A. Scorsone, \& J. B. Justice (Eds.), Handbook of Local Government Fiscal Health (pp. 405-430): Jones \& Bartlett.

Manna, P., \& Ryan, L. L. (2011). Competitive Grants and Educational Federalism: President Obama's Race to the Top Program in Theory and Practice. Publius: The Journal of Federalism, 41(3), 522-546. doi:10.1093/publius/pjr021

McDermott, K. A. (2006). Incentives, Capacity, and Implementation: Evidence from Massachusetts Education Reform. Journal of Public Administration Research and Theory, 16(1), 45-65. doi:10.1093/jopart/mui024 
McGranahan, L. (1999). State budgets and the business cycle: implications for the federal balanced budgets amendment debate. Economic Perspectives, 23(3), 3-17.

McGuinn, P. (2012). Stimulating Reform: Race to the Top, Competitive Grants and the Obama Education Agenda. Educational Policy, 26(1), 136-159. doi:10.1177/0895904811425911

McGuire, M., Rubin, B., Agranoff, R., \& Richards, C. (1994). Building Development Capacity in Nonmetropolitan Communities. Public Administration Review, 54(5), 426-433. doi:10.2307/976427

Mead, T. D. (1986). Issues in defining local management capacity. Perspectives on management capacity building, 24-46.

Mikesell, J. (2007). Changing State Fiscal Capacity and Tax Effort in an Era of Devolving Government, 1981-2003. Publius: The Journal of Federalism, 37(4), 532-550. doi:10.1093/publius/pjm016

Miller, J. G. (1965). Living systems: Basic concepts. Behavioral Science, 10(3), 193-237. doi:10.1002/bs.3830100302

Mueller, D. C. (2003). Public Choice III. Cambridge and New York: Cambridge University Press.

Mullins, D. R., \& Wallin, B. A. (2004). Tax and Expenditure Limitations: Introduction and Overview. Public Budgeting \& Finance, 24(4), 2-15. doi:10.1111/j.02751100.2004.00344.x

NASBO. (2009). State Expenditure Report 2009. Washington, DC: National Association of State Budget Officers.

NASBO. (2010). State Expenditure Report 2010. Washington, DC: National Association of State Budget Officers.

NCSL. (2010). NCSL FISCAL BRIEF: STATE BALANCED BUDGET PROVISIONS: National Conference of State Legislatures. 
Nesbit, T. M., \& Kreft, S. F. (2009). Federal Grants, Earmarked Revenues, and Budget Crowd-Out: State Highway Funding. Public Budgeting \& Finance, 29(2), 94-110. doi:10.1111/j.1540-5850.2009.00930.x

Nicholson-Crotty, S., \& Nicholson-Crotty, J. (2015). Politics, Capacity, and Pass-Through Decisions in the American States: Evidence from the American Recovery and Reinvestment Act. Publius: The Journal of Federalism. doi:10.1093/publius/pjv018

Nicholson-Crotty, S., \& Staley, T. (2012). Competitive Federalism and Race to the Top Application Decisions in the American States. Educational Policy, 26(1), 160-184. doi:10.1177/0895904811428974

Painter, M., \& Pierre, J. (2004). Challenges to state policy capacity: Global trends and comparative perspectives: Springer.

Pitts, D. W. (2005). Diversity, Representation, and Performance: Evidence about Race and Ethnicity in Public Organizations. Journal of Public Administration Research and Theory, 15(4), 615-631. doi:10.1093/jopart/mui033

Polidano, C. (2000). Measuring Public Sector Capacity. World Development, 28(5), 805822. doi:http://dx.doi.org/10.1016/S0305-750X(99)00158-8

Poterba, J. M. (1994). State Responses to Fiscal Crises: The Effects of Budgetary Institutions and Politics. Journal of Political Economy, 102(4), 799-821. doi:10.2307/2138765

Poterba, J. M. (1995a). Balanced budget rules and fiscal policy: evidence from the states. National Tax Journal, 48(3), 329-336. doi:10.2307/41789150

Poterba, J. M. (1995b). Capital budgets, borrowing rules, and state capital spending. Journal of Public Economics, 56(2), 165-187. doi:http://dx.doi.org/10.1016/00472727(94)01431-M

Ray, G., Barney, J. B., \& Muhanna, W. A. (2004). Capabilities, business processes, and competitive advantage: choosing the dependent variable in empirical tests of the resource-based view. Strategic Management Journal, 25(1), 23-37. doi:10.1002/smj.366 
Rebitzer, J. B. (1995). Is there a trade-off between supervision and wages? An empirical test of efficiency wage theory. Journal of Economic Behavior \& Organization, 28(1), 107-129. doi:http://dx.doi.org/10.1016/0167-2681(95)00023-0

Rich, M. J. (1989). Distributive Politics and the Allocation of Federal Grants. American Political Science Review, 83(01), 193-213. doi:doi:10.2307/1956440

Scheppach, R. C. (2012). The Intergovernmental Grant System. In R. D. Ebel \& J. E. Petersen (Eds.), The Oxford Handbook of State and Local Government Finance (pp. 937-957). New York: Oxford University Press.

Selden, S. C., \& Sowa, J. E. (2004). Testing a Multi-Dimensional Model of Organizational Performance: Prospects and Problems. Journal of Public Administration Research and Theory, 14(3), 395-416. doi:10.1093/jopart/muh025

Sitkin, S. B., Sutcliffe, K. M., \& Schroeder, R. G. (1994). Distinguishing Control From Learning in Total Quality Management: A Contingency

Perspective. Academy of Management Review, 19(3), 537-564. doi:10.5465/amr.1994.9412271813

Sokolow, A. D. (1989). Small local governments as community builders. National Civic Review, 78(5), 362-370. doi:10.1002/ncr.4100780506

Tannenwald, R., \& Cowan, J. (1997). Fiscal Capacity, Fiscal Need, and Fiscal Comfort among U.S. States: New Evidence. Publius: The Journal of Federalism, 27(3), 113126.

Terman, J., \& Feiock, R. (2014). Improving Outcomes in Fiscal Federalism: Local Political Leadership and Administrative Capacity. Journal of Public Administration Research and Theory. doi:10.1093/jopart/muu027

Terman, J., \& Feiock, R. (2015). Third-Party Federalism: Using Local Governments (and Their Contractors) to Implement National Policy. Publius: The Journal of Federalism, 45(2), 322-349. doi:10.1093/publius/pju041

Topinka, J. P. (2011). Does management capacity increase organizational performance? An empirical analysis of public housing agencies. (3484197 Ph.D.), Florida International University, Ann Arbor. Retrieved from 
http://ezproxy.fiu.edu/login?url=http://search.proquest.com/docview/903800470?a ccountid=10901 Dissertations \& Theses @ Florida International University - FCLA database.

Ukeles, J. B. (1982). Doing more with less: Turning public management around: Amacom.

United States Government Accountability Office. (2009). RECOVERY ACT: States' and Localities' Current and Planned Uses of Funds While Facing Fiscal Stresses. (GAO-09-829). Washington, D.C.

United States Government Accountability Office. (2011). Funding Used for Transportation Infrastructure Projects, but Some Requirements Proved Challenging. (GAO-11-600). Washington, D.C.

Van Slyke, D. M. (2003). The Mythology of Privatization in Contracting for Social Services. Public Administration Review, 63(3), 296-315. doi:10.1111/15406210.00291

Walden, M. L., \& Eryuruk, G. (2012). Determinants of Local Highway Spending in North Carolina. Growth and Change, 43(3), 462-481. doi:10.1111/j.14682257.2012.00594.x

Wang, T.-W. (2004). From general system theory to total quality management. Journal of American Academy of Business, 4(1/2), 394-400.

Wang, W., Hou, Y., \& Duncome, W. (2007). Determinants of Pay-as-You-Go Financing of Capital Projects: Evidence from the States. Public Budgeting \& Finance, 27(4), 1842. doi:10.1111/j.1540-5850.2007.00892.x

Wang, Y., \& Zhao, Z. J. (2014). Motivations, Obstacles, and Resources. Public Performance \& Management Review, 37(4), 679-704. doi:10.2753/PMR15309576370407

Wernerfelt, B. (1984). A Resource-Based View of the Firm. Strategic Management Journal, 5(2), 171-180.

World Bank. (1997). World Development Report 1997: The State in a Changing World. New York: Oxford University Press. (C) World Bank. 
Wyatt, D. F. G. (2009). The Perceived Challenges of Implementing the American Recovery and Reinvestment Act. State \& Local Government Review, 41(2), 128-132. doi:10.2307/25593639

Yang, K., Hsieh, J. Y., \& Li, T. S. (2009). Contracting Capacity and Perceived Contracting Performance: Nonlinear Effects and the Role of Time. Public Administration Review, 69(4), 681-696. doi:10.1111/j.1540-6210.2009.02017.x

Young, A., \& Sobel, R. (2013). Recovery and Reinvestment Act spending at the state level: Keynesian stimulus or distributive politics? Public Choice, 155(3-4), 449-468. doi:10.1007/s11127-011-9876-x

Zhao, Z., \& Guo, H. (2010). Management Capacity and State Municipal Bond Ratings: Evidence With the GPP Grades. The American Review of Public Administration. doi:10.1177/0275074010384718 


\section{APPENDIX}

\section{Survey Design and Progress}

The survey for DOTs of all 50 states was designed in order to supplement the secondary data analyses. As seen in appendix A, the survey questionnaire consists of three parts: grant application, human resource management, and transportation expenditure. I expected the survey would have been useful for explaining grant competition, measuring government capacity, and obtaining unreleased data for transportation expenditures of construction and maintenance. However, the survey is not utilized for the dissertation because of the low response rate (32\%) and the quality of responses.

The first distribution of the survey to 50 states was on April $8^{\text {th }}, 2016$, and followup invitations were sent five times, by using email and the Qualtrics system. I obtained contact information from each state's DOT website and AASHTO (American Association of State Highway and Transportation Officials). Before September $15^{\text {th }}$, sixteen states answered, six states denied answering, and the other twenty-eight states ignored the survey invitation.

I decided not to use survey answers for empirical analysis in the dissertation for several reasons. First, the number of responses was too small to utilize for regression models. Second, some respondents didn't answer several questions or left a few questions as N/A. Lastly, I discerned there are unreliable answers. For example, though question 1a (external consultant effort) and 1b (staffing effort) are related to each other, some states answered inconsistently. Albeit the shortcomings, however, I report survey questionnaires and the descriptive results of the survey for readers who might be interested. 


\section{Survey Questionnaire}

Part 1: Please answer the following five questions about your agency federal grant applications.

Q1: Some transportation agencies rely on little or no external technical assistance when they apply for federal grants. Other agencies utilize significant amount of external expertise for these applications.

Q1a: On a scale from 1 to 100, what is the percentage of external consultant effort in federal grant applications for the following years?

\begin{tabular}{l|l}
\hline Year & Percentage \\
\hline FY 2009 & \\
\hline FY 2010 & \\
\hline FY 2011 & \\
\hline FY 2012 & \\
\hline
\end{tabular}

Q1b: On a scale from 1 to 100, what is the percentage of staffing effort for the following years?

\begin{tabular}{l|l}
\hline Year & Percentage \\
\hline FY 2009 & \\
\hline FY 2010 & \\
\hline FY 2011 & \\
\hline FY 2012 & \\
\hline
\end{tabular}

Q2: Please state the amount your agency spent on external consultants on competitive grants (e.g., TIGER) application for the following years:

\begin{tabular}{l|l}
\hline Year & Amount (in \$) \\
\hline FY 2009 & \\
\hline FY 2010 & \\
\hline FY 2011 & \\
\hline FY 2012 & \\
\hline
\end{tabular}

Q3: A lot of emphasis was placed on shovel readiness of projects considered for competitive grants (e.g., TIGER) funding. On a scale of 1 to 100, how would you rate the shovel readiness of the transportation projects in your state for the following years?

\begin{tabular}{l|l}
\hline Year & Rate \\
\hline FY 2009 & \\
\hline FY 2010 & \\
\hline FY 2011 & \\
\hline FY 2012 & \\
\hline
\end{tabular}


Q4: State your level of agreement with the following statement:

Congressional oversight of competitive grants (e.g., TIGER) funding was more intense than prior federal transportation grants.

\begin{tabular}{l|l|l|l|l}
\hline Strongly Agree & Agree & Neutral & Disagree & Strongly Disagree \\
\hline & & & & \\
\hline
\end{tabular}

Q5: On a scale of 1 to 100, how would you rate the level of complexity of competitive grants (e.g., TIGER) applications in each of the following years?

\begin{tabular}{l|l}
\hline Year & Rate \\
\hline FY 2009 & \\
\hline FY 2010 & \\
\hline FY 2011 & \\
\hline FY 2012 & \\
\hline
\end{tabular}

Q6: For how many competitive grants did your agency apply (including TIGER) in the following years?

\begin{tabular}{l|l}
\hline Year & Number \\
\hline FY 2009 & \\
\hline FY 2010 & \\
\hline FY 2011 & \\
\hline FY 2012 & \\
\hline
\end{tabular}

Part 2: The following set of questions refers to your agency staff and management practices.

Q7: For each of the following years, what percentage of your workforce approximately held the PE (Professional Engineer) designation?

\begin{tabular}{l|l}
\hline Year & Percentage \\
\hline FY 2009 & \\
\hline FY 2010 & \\
\hline FY 2011 & \\
\hline FY 2012 & \\
\hline
\end{tabular}

Q8: For each of the following years, approximately what percent of your management staff held an advanced degree (e.g., master's, PhD or JD)?

\begin{tabular}{l|l}
\hline Year & Percentage \\
\hline FY 2009 & \\
\hline FY 2010 & \\
\hline FY 2011 & \\
\hline FY 2012 & \\
\hline
\end{tabular}


Q9: For each of the following years, list the percentage of your permanent FTE agency workforce that is exempt from civil service protection?

\begin{tabular}{l|l}
\hline Year & Percentage \\
\hline FY 2009 & \\
\hline FY 2010 & \\
\hline FY 2011 & \\
\hline FY 2012 & \\
\hline
\end{tabular}

Q10: What percentage of your workforce voluntarily separated during the following years?

\begin{tabular}{l|l}
\hline Year & Percentage \\
\hline FY 2009 & \\
\hline FY 2010 & \\
\hline FY 2011 & \\
\hline FY 2012 & \\
\hline
\end{tabular}

Q11: Approximately what percentage of agency payroll was devoted to training and related employee development in each of the following years?

\begin{tabular}{l|l}
\hline Year & Percentage \\
\hline FY 2009 & \\
\hline FY 2010 & \\
\hline FY 2011 & \\
\hline FY 2012 & \\
\hline
\end{tabular}

Q12: Many public agencies are suffering from “a graying workforce” and subsequent "drain of institutional memory." Using the scale below, how would characterize this age drain in your agency for the following years?

$$
1=\text { insignificant } 2=\text { =moderately significant } 3=\text { significant } 4=\text { very significant } 5=\text { intense }
$$

\begin{tabular}{l|l}
\hline Year & Scale \\
\hline FY 2009 & \\
\hline FY 2010 & \\
\hline FY 2011 & \\
\hline FY 2012 & \\
\hline
\end{tabular}

Q13: Some agencies focus on the control of expenses, others focus on efficiency, and a third group of agencies is more concerned with the effectiveness of their outlays. Please rate the importance of each by assigning a percentage weight (all weights should add to $100 \%)$ :

\begin{tabular}{l|l}
\hline Value & Percentage \\
\hline Control & \\
\hline Efficiency & \\
\hline Effectiveness & \\
\hline Total & $100 \%$ \\
\hline
\end{tabular}


Q14: How would you characterize your agency performance management culture to the extent division level budget allocations and individual salaries are driven by objective achievement of results? On a scale from 1 to 100, please rate performance management culture of your agency for each of the following years?

\begin{tabular}{l|l|}
\hline $\begin{array}{l}\text { 1=last budget level and salaries are principal drivers } \\
\text { 100=budget allocations and salary increases based on the achievement of } \\
\text { predetermined performance levels }\end{array}$ \\
\hline Year & Rate \\
\hline FY 2009 & \\
\hline FY 2010 & \\
\hline FY 2011 & \\
\hline FY 2012 & \\
\hline
\end{tabular}

Q15: How would you assess your agency ability to track performance in real time using information technology?
Letter Grade: A B
$\mathrm{C}$
D $\quad \mathrm{F}$

Q16: Transparency is an integral part of public management. How would a citizen with a high-school diploma assess the transparency of your agency in term of performance reporting?
Letter Grade: A
B
C
D F

Q17: How would an elected official assess the transparency of your agency in term of performance reporting?
Letter Grade: A
B
C
D F

Part 3: Please answer the following question about your agency transportation expenditure.

Q18: Please state the amount (in \$) your agency spent on new construction and maintenance of transportation infrastructure in the following years:

\begin{tabular}{l|l|l}
\hline Year & New construction & Maintenance \\
\hline FY 2009 & & \\
\hline FY 2010 & & \\
\hline FY 2011 & & \\
\hline FY 2012 & & \\
\hline
\end{tabular}

Please take a moment to tell us more about yourself (Optional):

\begin{tabular}{l|l}
\hline State & \\
\hline Your Name & \\
\hline Your Title & \\
\hline Your agency & \\
\hline E-mail Address & \\
\hline Phone number & \\
\hline
\end{tabular}




\section{Survey Findings}

Part 1. Grant application

1.1. External consultant vs. staffing effort (Q1)

\begin{tabular}{l|l|l|l|l|l|l|l|l|l}
\hline Year & Obs. & \multicolumn{4}{|l|}{ External consultant } & \multicolumn{2}{l}{ Staffing effort } \\
\cline { 3 - 11 } & & Mean & Std. Dev. & Min & Max & Mean & Std. Dev. & Min & Max \\
\hline FY 2009 & 15 & 27.53 & 34.93 & 0 & 90 & 48.07 & 41.56 & 0 & 100 \\
\hline FY 2010 & 15 & 28.80 & 35.16 & 0 & 90 & 48.13 & 42.12 & 0 & 100 \\
\hline FY 2011 & 15 & 30.00 & 37.18 & 0 & 90 & 46.33 & 43.63 & 0 & 100 \\
\hline FY 2012 & 15 & 27.47 & 35.97 & 0 & 90 & 50.27 & 43.43 & 0 & 100 \\
\hline
\end{tabular}

1.2. Costs of external consultants (Q2)

\begin{tabular}{l|l|l|l|l|l}
\hline Year & Obs. & Mean & Std. Dev. & Min & Max \\
\hline FY 2009 & 9 & 548894.4 & 1594523 & 0 & 4800000 \\
\hline FY 2010 & 9 & 554653.6 & 1592385 & 0 & 4800000 \\
\hline FY 2011 & 10 & 495005 & 1512959 & 0 & 4800000 \\
\hline FY 2012 & 10 & 496005 & 1512606 & 0 & 4800000 \\
\hline
\end{tabular}

1.3. Shovel readiness $(\mathrm{Q} 3)$

\begin{tabular}{l|l|l|l|l|l}
\hline Year & Obs. & Mean & Std. Dev. & Min & Max \\
\hline FY 2009 & 14 & 80.78571 & 25.54386 & 25 & 100 \\
\hline FY 2010 & 13 & 78.07692 & 26.19625 & 25 & 100 \\
\hline FY 2011 & 14 & 77.71429 & 27.88556 & 25 & 100 \\
\hline FY 2012 & 13 & 76.84615 & 29.48968 & 18 & 100 \\
\hline
\end{tabular}

1.4. Perception on congressional oversight (Q4)

\begin{tabular}{l|l|l|l|l}
\hline Obs. & Mean & Std. Dev. & Min & Max \\
\hline 15 & 3.2 & 1.264911 & 1 & 5 \\
\hline
\end{tabular}

1.5. Complexity of competitive grants applications (Q5)

\begin{tabular}{l|l|l|l|l|l}
\hline Year & Obs. & Mean & Std. Dev. & Min & Max \\
\hline FY 2009 & 15 & 63.66667 & 16.51262 & 25 & 92 \\
\hline FY 2010 & 14 & 62.14286 & 11.61469 & 50 & 93 \\
\hline FY 2011 & 15 & 59.93333 & 13.23667 & 40 & 92 \\
\hline FY 2012 & 14 & 58.21429 & 12.70481 & 40 & 93 \\
\hline
\end{tabular}


Part 2. Human resource management

2.1. PE designation (Q7) in workforce and Education level (Q8)

\begin{tabular}{l|l|l|l|l|l|l|l|l|l|l}
\hline Year & Obs. & \multicolumn{3}{|c|}{ PE designation in workforce } & \multirow{2}{*}{ Obs. } & \multicolumn{3}{|c}{ \% of advanced degree } \\
\cline { 4 - 9 } & & Mean & Std. Dev. & Min & Max & & Mean & Std. Dev. & Min & Max \\
\hline FY 2009 & 11 & 13.11 & 10.82 & 3 & 37 & 10 & 8.49 & 8.72 & 0.6 & 24 \\
\hline FY 2010 & 11 & 13.33 & 10.77 & 3 & 36.9 & 10 & 8.79 & 9.53 & 0.5 & 28 \\
\hline FY 2011 & 11 & 13.23 & 10.58 & 3.8 & 36.4 & 10 & 8.64 & 9.31 & 0.4 & 27 \\
\hline FY 2012 & 11 & 13.15 & 10.54 & 3.7 & 36.1 & 10 & 8.88 & 9.53 & 0.5 & 28 \\
\hline
\end{tabular}

2.2. Civil service protection (Q9) and voluntarily separated workforce (Q10)

\begin{tabular}{l|l|l|l|l|l|l|l|l|l|l}
\hline \multirow{2}{*}{ Year } & Obs. & \multicolumn{3}{|c|}{ PE designation in workforce } & \multirow{2}{*}{ Obs. } & \multicolumn{3}{|c}{ \% of voluntary separation } \\
\cline { 3 - 8 } \cline { 8 - 11 } & & Mean & Std. Dev. & Min & Max & & Mean & Std. Dev. & Min & Max \\
\hline FY 2009 & 14 & 16.34 & 35.69 & 0 & 100 & 12 & 12.31 & 22.23 & 3 & 82 \\
\hline FY 2010 & 14 & 15.87 & 35.79 & 0 & 100 & 12 & 13.09 & 24.47 & 1.7 & 90 \\
\hline FY 2011 & 14 & 16.07 & 35.80 & 0 & 100 & 13 & 13.02 & 22.54 & 2 & 87 \\
\hline FY 2012 & 14 & 16.37 & 35.81 & 0 & 100 & 13 & 12.41 & 22.97 & 1 & 88 \\
\hline
\end{tabular}

2.3. Percentage of agency payroll regarding training and development programs (Q11)

\begin{tabular}{l|l|l|l|l|l}
\hline Year & Obs. & Mean & Std. Dev. & Min & Max \\
\hline FY 2009 & 13 & 3.04 & 3.51 & 0 & 11 \\
\hline FY 2010 & 13 & 3.08 & 3.48 & 0 & 11 \\
\hline FY 2011 & 13 & 2.99 & 3.50 & 0 & 11 \\
\hline FY 2012 & 13 & 3.01 & 3.52 & 0 & 11 \\
\hline
\end{tabular}

2.4. Performance budget (Q14)

\begin{tabular}{l|l|l|l|l|l}
\hline Year & Obs. & Mean & Std. Dev. & Min & Max \\
\hline FY 2009 & 13 & 3.04 & 3.51 & 0 & 11 \\
\hline FY 2010 & 13 & 3.08 & 3.48 & 0 & 11 \\
\hline FY 2011 & 13 & 2.99 & 3.50 & 0 & 11 \\
\hline FY 2012 & 13 & 3.01 & 3.52 & 0 & 11 \\
\hline
\end{tabular}

2.5. Performance management and transparency

\begin{tabular}{l|l|l|l|l|l}
\hline Question & Obs. & Mean & Std. Dev. & Min & Max \\
\hline IT utilization (Q15) & 16 & 3.44 & 1.15 & 1 & 5 \\
\hline Citizens' assessment (Q16) & 16 & 3.50 & 1.26 & 1 & 5 \\
\hline Elected official's assessment (Q17) & 16 & 3.69 & 1.08 & 1 & 5 \\
\hline
\end{tabular}


Part 3. New construction vs. maintenance cost (Q18)

\begin{tabular}{|c|c|c|c|c|c|c|c|c|c|c|}
\hline \multirow[t]{2}{*}{ Year } & \multirow[t]{2}{*}{ Obs. } & \multicolumn{4}{|c|}{ New construction } & \multirow[t]{2}{*}{ Obs. } & \multicolumn{4}{|c|}{ Maintenance } \\
\hline & & Mean & Std. Dev. & Min & Max & & Mean & Std. Dev. & Min & Max \\
\hline FY 2009 & 12 & 1.70 & $2,926.03$ & 799.73 & 855.11 & 12 & 133.00 & $3,119.55$ & 888.63 & $1,004.82$ \\
\hline FY 2010 & 12 & 1.70 & $1,951.26$ & 741.64 & 737.74 & 12 & 124.00 & $2,685.60$ & 812.15 & 867.46 \\
\hline FY 2011 & 12 & 1.40 & $2,155.89$ & 665.10 & 664.32 & 12 & 122.35 & $3,150.25$ & 925.74 & $1,052.48$ \\
\hline FY 2012 & 12 & 1.40 & $2,169.97$ & 724.65 & 801.90 & 12 & 122.34 & $3,819.27$ & 976.41 & $1,208.65$ \\
\hline
\end{tabular}


VITA

\section{NAKHYEOK CHOI}

1999-2005

B.A., Public Administration

B.A., Political Science

DongGuk University

Seoul, South Korea

$2008-2010$

M.A., Public Administration

Seoul National University

Seoul, South Korea

$2012-2016$

Ph.D., Public Affairs

Florida International University

Miami, Florida

\section{PUBLICATIONS AND PRESENTATIONS}

Nakhyeok Choi and Milena Neshkova, Inequality and Competition in State Redistributive Systems: Evidence from Welfare and Health, Under review (Revised and Resubmited) at American Review of Public Administration

Nakhyeok Choi, Efficiency and Effectiveness in Infrastructure management: Evidence from U.S. Highway management, Under review

Arwiphawee Srithongrung and Nakhyeok Choi. Local Government Optimal Tax Rate: A Stochastic Frontier Analysis Approach, Under review

Nakhyeok Choi and Huck-ju Kwon (2010), Fixed-term Worker's Transition to the Status of Regular Contracts: An Event History Analysis of Determinants, Korean Journal of Policy Analysis and Evaluation, 20(2): p.165-184

Nakhyeok Choi, Milena Neshkova, and Tobin Im. Government Competitiveness in Grant-inAid Systems. Paper presented at the 2016 Annual Conference of American Society of Public Administration (ASPA), Seattle, WA., U.S., March 18-22, 2016. 
Nakhyeok Choi. Infrastructure Finance's Effectiveness and Efficiency Paper presented at the 2015 Annual Conference of Association for Public Policy Analysis \& Management (APPAM). Miami, U.S., November 12-14, 2015.

Arwiphawee Srithongrung \& Nakhyeok Choi. Allocative Efficiency across Public Service Functions for City Infrastructure: Are V.O. Key’s Criteria Fruitful? Paper presented at the 2015 Annual Conference of Association for Budgeting \& Financial Management (ABFM). Washington, DC., U.S., October 1-3, 2015.

Nakhyeok Choi. Institution and Capital Budget Performance in Local Governments: Florida counties case. Paper presented at the 2015 Annual Conference of Urban Affair Association (UAA), Miami, FL., U.S., April 8-11, 2015

Nakhyeok Choi. Institution and Capital Budget Performance in Local Governments. Paper presented at the 2015 Annual Conference of American Society of Public Administration (ASPA), Chicago, IL., U.S., March 6-10, 2015

Nakhyeok Choi \& Hai Guo. Redistributive Spending in Hard Times - A Spatial Analysis of State TANF and Medicaid Spending. Paper presented at the Annual Conference of Association for Budgeting \& Financial Management (ABFM). Grand Rapids, MI. October 2-4, 2014.

Nakhyeok Choi. Sustainable Development and Redistributive Policy: TANF and Medicaid. Paper presented at the 2014 Southeastern Conference of Public Administration (SECoPA), Atlanta, GA., U.S., September 17-20 2014.

Nakhyeok Choi. Interregional competition on Welfare Expenditure. Discussion circle paper presented at the 2014 Annual Conference of American Society of Public Administration (ASPA). Washington, DC., U.S., March 15-17, 2014.

Nakhyeok Choi. Race to the Bottom? Relative Benefits' Impact on Welfare Expenditure. Paper presented at the 25th Annual Conference of Association of Budgeting and Financial Management (ABFM). Washington, DC., U.S., October 3-5, 2013.

Nakhyeok Choi and Huck-ju Kwon (2010, March). Fixed-term Worker's Transition to the Status of Regular Contracts: An Event History Analysis of Determinants. Paper presented at the Conference of Seoul Public Administration Association, Seoul, Korea. 